CAMILA ERCOLINI BARROSO

Aspectos quantitativo e biomolecular da vascularização do timo em gatos

São Paulo

2012 


\section{Aspectos quantitativo e biomolecular da vascularização do timo em gatos}

Tese apresentada ao Programa de PósGraduação em Anatomia dos Animais Domésticos e Silvestres da Faculdade de Medicina Veterinária e Zootecnia da Universidade de São Paulo para obtenção do título de Doutor em Ciências

Departamento:

Cirurgia

Área de Concentração:

Anatomia dos Animais Domésticos e Silvestres

Orientador:

Prof. Dr. Pedro Primo Bombonato

Co-orientador:

Prof. Dr. José Roberto Kfoury Jr. 
Autorizo a reprodução parcial ou total desta obra, para fins acadêmicos, desde que citada a fonte.

DADOS INTERNACIONAIS DE CATALOGAÇÃO-NA-PUBLICAÇÃO

(Biblioteca Virginie Buff D’Ápice da Faculdade de Medicina Veterinária e Zootecnia da Universidade de São Paulo)

Barroso, Camila Ercolini

Aspectos quantitativo e biomolecular da vascularização do timo em gatos / Camila Ercolini Barroso. -- 2012.

$108 \mathrm{f}$.

Tese (Doutorado) - Universidade de São Paulo. Faculdade de Medicina Veterinária e Zootecnia. Departamento de Cirurgia, São Paulo, 2012.

Programa de Pós-Graduação: Anatomia dos Animais Domésticos e Silvestres.

Área de concentração: Anatomia dos Animais Domésticos e Silvestres.

Orientador: Prof. Dr. Pedro Primo Bombonato.

Co-orientador: Prof. Dr. José Roberto Kfoury Jr.

1. Sistema linfóide. 2. Timo. 3. VEGF. 4. Vascularização. 5. Microambiente tímico. I. Título. 


\section{MACUI DADE DE MEDICINA VETERINARIA E ZOOTECNIA}

\section{Comissão de Ética no uso de animais}

\section{CERTIFICADO}

Certificamos que o Projeto intitulado "Aspectos quantitativo e biomolecular da vascularização do timo em gatos", protocolado sob o n $1676 / 2009$, utilizando 72 (setenta e dois) gatos, sob a responsabilidade do Prof. Dr. Pedro Primo Bombonato, está de acordo com os princípios éticos de experimentação animal da "Comissão de Ética no uso de animais" da Faculdade de Medicina Veterinária e Zootecnia da Universidade de São Paulo e foi aprovado em reunião de $17 / 6 / 2009$.

We certify that the Research "Quantitative and biomolecular aspects of the vascularization in cats' thymus", protocol number 1676/2009, utilizing 72 (seventy two) cats, under the responsibility Prof. Dr. Pedro Primo Bombonato, agree with EthicalPrinciples in Animal Research adopted by "Ethic Committee in the use of animals" of the School of Veterinary Medicine and Animal Science of University of São Paulo and was approved in the meeting of day 6/17/2009.

São Paulo, 29 de março de 2012.

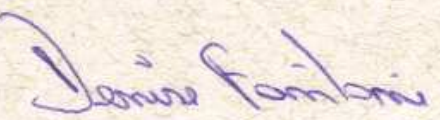

Denise Tabacchi Fantoni

Presidente 


\section{FOLHA DE AVALIAÇÃO}

Nome: Barroso, Camila Ercolini

Título: Aspectos quantitativo e biomolecular da vascularização do timo em gatos

Tese apresentada ao Programa de PósGraduação em Animais Domésticos e Silvestres da Faculdade de Medicina Veterinária e Zootecnia da Universidade de São Paulo para obtenção do título de Doutor em Ciências

Data:

Banca Examinadora

Prof. Dr.:

Instituição: Julgamento:

Prof. Dr.:

Instituto:

Julgamento:

Prof. Dr.:

Instituto: Julgamento:

Prof. Dr.:

Instituto: Julgamento:

Prof. Dr.:

Instituto: Julgamento: 
Esta pesquisa foi financiada pela FUNDAÇÃO DE APOIO À PESQUISA DO ESTADO DE SÃO PAULO - FAPESP, sob os processos 08/58096-5 e 10/52480-8 


\section{Dedica}

Aas meus amadas pais, Isaleel e Márcia, pela apaia e dedicaçãa que me ofertaram tada este tempa

à minha querida irmã, Caraline, pela carinha e apaia

Aas meus auós, Anileal (in memariam) e Margarida, que sempre me ofertaram carinha e amor

Aa André, meu marida, pela carinha e paciência 


\section{Agradecimentos especiais}

a Deus pela apartunidade de viver, crescer e aprender sempre....

a Nassa Senhara das Graças par interceder par mim e estar sempre aa meu lada

Jesus disse: Eu sau a caminha, e a verdade, e a vida; ninguém vem aa Pai senãa par mim.” (Jaãa 14.6) 


\section{Agradecimentos especiais}

Aa meu querida arientadar Praf. Dr. Pedra Prima Bambanata pela canfiança, amizade e ensinamentas. Mesma quanda teve que se ausentar nas ensinau muita

Aa meu ca-arientadar Praf. Dr. Jasé Ralerta Kfaury Fr. que me acalheu em momentos dificeis e me ajudau a finalizar este trabalka

\footnotetext{
à Praf. Dra. Maria Angélica Miglina pela opartunidade, pelas ensinamentas e pela grande ajuda que nas ofertau nas mamentas dificeis que passamas
} 


\section{Agradecimentos}

A toda a minha família e amigos pelo carinho, atenção e apoio.

Aos meus amigos Prof. Dr. Fernando e D. Nilse de Oliveira, pessoas de coração nobre que sempre me incentivaram e apoiaram desde o começo da minha carreira.

À Faculdade de Medicina Veterinária e Zootecnia da Universidade de São Paulo (FMVZ-USP) que me acolheu e proporcionou a subida de mais um degrau em minha formação.

À Prof. Dra. Paula de Carvalho Papa por ter me concedido o uso do Laboratório LEME.

Às pós-graduandas do Laboratório LEME que me auxiliaram na elaboração de todo o protocolo do PCR e análises, Luciana, Renata e Liza.

Ao Prof. Dr. Francisco Javier Hernandez Blazquez por ceder o laboratório para o desenvolvimento da pesquisa e pelos ensinamentos em disciplinas.

Ao Prof. Dr. Carlos Mandarim-de-Lacerda pela receptividade no Laboratório de Morfologia e Morfometria Cardiovascular (LMMC) da Universidade Estadual do Rio de Janeiro, pela atenção e ensinamentos dispensados por ele e por seus alunos.

À Prof. Dra. Ana Paula Vidotti pelos apontamentos e sugestões no Exame de Qualificação e amizade.

Aos amigos da clínica veterinária Hipopet, seus funcionários e aos veterinários Gustavo Sato e Viviane Benvenga.

Aos companheiros de sala e orientador: Fernanda Rodrigues Agreste, Caio Biasi, Yuri Karacas, Luana Célia Stunitz da Silva, Marcello Machado, Rafael Senos, Rafael Cisne e Rafael Agopian, pelo compartilhamento de conhecimentos científicos e pela companhia.

Aos meus amigos André, Juliana Ferrão, Marcos, Renata Fontinele e Fernanda pela companhia e amizade ofertadas. 
Ao meu amigo Yuri Karacas, pelos momentos de amizade e apoio.

À minha amiga Fernanda Rodrigues Agreste pela grande amizade.

Aos amigos Bruno Cogliati e Thiago Aloia pela amizade, ajuda e confiança por ceder o laboratório para realização deste trabalho.

À Luana Célia Stunitz da Silva pela amizade.

Ao Diogo Palermo Neto, técnico do Laboratório de Anatomia Microscópica e Imunohistoquímica, pelos ensinamentos e amizade.

Ao Ronaldo Agostinho da Silva, técnico do Laboratório de Histologia e Embriologia pelos ensinamentos e amizade.

Ao Edinaldo Ribas Farias, técnico do Laboratório de Anatomia Macroscópica (LAM) pelas conversas, risadas e ensinamentos.

Às amigas do LTIAM, Janaína Munuera Monteiro, Maria Letícia Salvadori, Rosemary Viola Bosch e Ana Rita Lima pelo companheirismo e amizade.

Aos amigos Jaqueline Martins de Santana e Maicon Silva, secretários do Setor de Anatomia dos Animais Domésticos e Silvestres da FMVZ-USP, pela prestatividade e amizade.

Aos funcionários do Museu de Anatomia Veterinária (MAV) Prof. Dr. Plínio Pinto e Silva, João do Carmo Freitas, Raimundo Leal de Sousa, Branca e Fátima pela atenção, ensinamentos e auxílios nas atividades curriculares.

Aos funcionários da Biblioteca Virginie Buff D’Ápice, pela paciência, amizade e prestatividade ofertada quando eu precisava, especialmente à Helena, Elza Faquim e Solange A. Santana.

Aos funcionários da secretaria de Pós-Graduação da FMVZ-USP.

A todos os amigos de pós-graduação, pelos momentos de amizade e descontração, risadas e momentos de apoio, especialmente à: André Franciolli, Juliana Passos, Felipinho, Márcio, Marininha, João Morini, Valquíria ....

A todos os animais que cederam sua vida para a realização deste trabalho, os meus mais sinceros votos de agradecimento e ternura. 


\section{LISTA DE ABREVIATURAS E SIGLAS}

\begin{tabular}{|c|c|}
\hline $\mathrm{m}$ & milímetro \\
\hline $\mathrm{cm}$ & centímetro \\
\hline SNA & sistema nervoso autônomo \\
\hline B & beta \\
\hline SRD & sem raça definida \\
\hline PBS & solução salina tamponada fosfatada \\
\hline M & molar \\
\hline${ }^{\circ} \mathrm{C}$ & Graus Celsius \\
\hline$\mu \mathrm{m}$ & micrômetro \\
\hline$\mu g$ & micrograma \\
\hline$V_{\text {(ref) }}$ & Volume Referência \\
\hline$d$ & distância para cortes macroscópicos \\
\hline$k$ & distância para cortes microscópicos \\
\hline$\Sigma a$ & somatória das áreas \\
\hline CE & coeficiente de erro \\
\hline AUI & Aleatórios e Uniformemente Isotrópicos \\
\hline IUR & Isotropic Uniform Random \\
\hline$\Phi$ & seno \\
\hline$\Theta$ & co-seno \\
\hline $\mathrm{mm}^{2}$ & milímetro quadrado \\
\hline $\mathrm{a}$ & área \\
\hline $\mathrm{p}$ & número de pontos \\
\hline
\end{tabular}




\begin{tabular}{|c|c|}
\hline $\mathrm{h}$ & altura \\
\hline At & área teste \\
\hline $\mathrm{V}_{\text {(dis) }}$ & volume do disector \\
\hline $\mathrm{H}$ & hole \\
\hline I & island \\
\hline B & bridge \\
\hline$X_{v}$ & número de Euler \\
\hline $\mathrm{N}_{\mathrm{v}(\text { vasc })}$ & densidade numérica vascular \\
\hline$N_{\text {(vasc) }}$ & número de vasos \\
\hline L & comprimento do vaso \\
\hline Lv & densidade de comprimento do vaso \\
\hline S & superfície de área \\
\hline Sv & densidade de superfície de área \\
\hline Qa & número de perfis por área \\
\hline$I_{L}$ & número de intersecções \\
\hline $\mathrm{cm}^{3}$ & centímetro cúbico \\
\hline DP & desvio padrão \\
\hline $\mathrm{pH}$ & potencial hidrogeniônico \\
\hline MEV & microscopia eletrônica de varredura \\
\hline DEPC & dietil pirocarbonato \\
\hline RNA & ácido ribonucleico \\
\hline DNA & ácido desoxirribonucleico \\
\hline PBS & solução salina tamponada com fosfato \\
\hline PCR & reação em cadeia da polimerase \\
\hline GAPDH & gliceraldeído fosfato desidrogenase \\
\hline
\end{tabular}


KDR receptor de domínio de inserção de quinase

Flt-1 receptor 1 de tirosina-quinase

Flt-4 receptor 4 de tirosina-quinase

mRNA ácido ribonucleico mensageiro

RNAse ribonuclease

RT transcrição reversa

VEGF fator de crescimento endotelial vascular

VEGFR-1 receptor 1 do fator de crescimento endotelial vascular

VEGFR-2 receptor 2 do fator de crescimento endotelial vascular

VEGFR-3 receptor 3 do fator de crescimento endotelial vascular

APES 3-aminopropyltrietroxy-silano 


\section{RESUMO}

BARROSO, C. E. Aspectos quantitativo e biomolecular da vascularização do timo em gatos. [Quantitative and biomolecular aspects of the thymus vascularization in cat]. 2012. 107 f. Tese (Doutorado em Ciências) - Faculdade de Medicina Veterinária e Zootecnia, Universidade de São Paulo, São Paulo, 2012.

O sistema linfoide é composto de órgãos linfoides primários e secundários. O timo é um órgão linfoide primário responsável pela maturação, diferenciação e seleção da linhagem linfocitária do tipo T que é responsável pela imunidade celular do indivíduo. Para cumprir estas funções, o timo possui uma disposição peculiar das suas células epiteliais morfologicamente distintas e de suas estruturas vasculares. Seus vasos sanguíneos possuem um papel na oxigenação tecidual e no processo de migração das células precursoras de linfócitos $\mathrm{T}$ para o interior do parênquima tímico e por isso apresentam uma arquitetura típica caracterizada por vasos de grande calibre, localizados na junção cortico-medular e uma fina rede de ramos e anastomoses que se estendem para o córtex. Este processo de estruturação e arquitetura vascular ainda possui sua base molecular desconhecida, assim como os mecanismos que provocam a involução do órgão. O VEGF é um fator angiogênico que atua na formação vascular e na modulação de funções relacionadas à vascularização, sendo um importante marcador da angiogênese. A fim de se melhor compreender o comportamento vascular na formação e involução tímica, propôs-se avaliar a expressão gênica e proteica deste fator durante fases de desenvolvimento e involução do órgão, além da quantificação da vascularização do timo pela técnica estereológica, análise do parênquima tímico pela técnica de microscopia eletrônica de varredura e análise dos tipos celulares presentes em cada estágio etário. Para tal utilizou-se amostras de timo de gato em quatro estágios de desenvolvimento fetal $(35,45,55,65)$, e dois estágios pós-natal (6 meses e 1 ano) para a realização da imuno-histoquimica, PCR em tempo real e MEV, e para a técnica estereológica 2 estágios pós-natal (6 meses e 1 ano). Na microscopia eletrônica de varredura foram observados os timócitos de diferentes tamanhos, em estágios de maturação distintos. As proteínas do VEGF-A e dos receptores Flt-1 e KDR foram identificadas no timo de gatos em todas as fases do desenvolvimento foram localizadas no 
citoplasma de células epiteliais, endoteliais e no interior dos corpúsculos tímicos. A expressão do mRNA no período de 1 ano de idade a expressão do mRNA do VEGF e seus receptores tem um aumento significativo, coincidindo com a diminuição do $N_{\text {vasc }}$ e do $N_{v(\text { vasc })}$ podendo causar um estado de hipóxia no órgão levando a um aumento compensatório de sistema VEGF. A curva de crescimento vascular obedece a um padrão de desenvolvimento e involução do órgão.

Palavras-chave: Sistema linfóide. Timo. VEGF. Vascularização. Microambiente tímico. 


\section{ABSTRACT}

BARROSO, C. E. Quantitative and biomolecular aspects of the thymus vascularization in cat. [Aspectos quantitativo e biomolecular da vascularização do timo em gatos]. 2012. 107 f. Tese (Doutorado em Ciências) - Faculdade de Medicina Veterinária e Zootecnia, Universidade de São Paulo, São Paulo, 2012.

The lymphoid system is composed by primary and secondary lymphoid organs. The thymus is a primary lymphoid organ responsible for maturation, differentiation and selection of the lymphoid $T$ cell lineage that is responsible for cellular immunity. To accomplish these functions has a peculiar arrangement with morphologically distinct epithelial cells and vascular structures. The blood vessels have a role in tissue oxygentation and the migration of $\mathrm{T}$ cells into the thymic parenchyma, therefore they presents large vessels in cortico-medullary junction and a fine network branches to the cortex. This process has its molecular basis unknown as well as the involution process of the thymus. VEGF is an angiogenic factor that plays a role in the formation and modulation of vascular functions, being an important marker of angiogenesis. We proposed to evaluate the gene and protein expression of VEGF during the thymus development and involution, stereological quantification and scanning electron microscopy. Samples of cat's thymus from 35, 45, 55, 65 days of development and 6 months and 1 year of age. In scanning electronic microscopy different stages maturation thymocytes were observed. Protein expression of VEGF and its receptors were identified in all development stages in epithelial cells, endothelial cells and thymic corpuscles. The VEGF mRNA expression and its receptors in 1 year old animals was significantly increased, coinciding with the decreasing $N_{\text {vasc }}$ and the $N_{v(v a s c)}$ causing a hypoxic condition in the thymus resulting in a compensatory increase of VEGF system. The vascular growth curve follows a pattern of development and involution of the organ.

Key words: Lymphoid system. Thymus. VEGF. Vascularization. Thymic microenvironment. 


\section{LISTA DE FIGURAS}

Figura 1 llustração demonstra a cavidade torácica de gato comos pulmões seccionados. Timo (seta preta); A: brônquios seccionados e vasos pulmonares; B: coração com pericárdio; *: nervo frênico; D: veia cava caudal; E: esôfago; F: aorta. (Fonte: Hudson; Hamilton, 1993.

Figura 2 Sistemas testes com diferentes ângulos utilizados no método orientator. A - relógio $\boldsymbol{\theta}$ (co-seno) ou $\boldsymbol{\theta}$ - clock. $\mathrm{B}$ - relógio $\boldsymbol{\phi}$ (seno) ou $\phi$-clock. Fonte: Adaptado de Mandarim-de-Lacerda (2003)

Figura 3 Em A, a "reference section" é delimitada por uma área teste com linhas de inclusão (linhas pontilhadas) e de exclusão (linhas cheias). Em B, a "look-up section" é delimitada por uma área teste rígida.

Figura 4 Amostragem do disector e estimação dos planos tangenciais. Em A, a superfície convexa do capilar é mostrado na "reference setion" e não na "Look-up section", estruturas chamadas de "Hole". Em B, uma irregularidade da parede do capilar é observada conferindo uma nova parte isolada chamada de "Island". Em C, na "reference section" a curvatura é côncava, e na "look-up section" a curvatura é do tipo convexa formando uma divisão do lúmen capilar em dois ou mais lumens, chamados também de "Bridge".

Figura 5 Fotomicrografias da localização da proteína VEGF-A em timo de gatos. A: feto com 35 dias de desenvolvimento, $200 \mu \mathrm{m}$. B: feto com 45 dias de desenvolvimento, $200 \mu \mathrm{m}$. C: feto com 55 dias de desenvolvimento, $50 \mu \mathrm{m}$. D: feto com 65 dias de gestação, $50 \mu \mathrm{m}$. E: 6 meses pós-natal, $20 \mu \mathrm{m}$. F: 1 ano de idade, $50 \mu \mathrm{m}$. Legenda: CE célula endotelial, CT- corpúsculo tímico, M -zona medular, seta cápsula tímica.

Figura 6 Fotomicrografias da localização da proteína KDR em timos de gatos. A: feto com 35 dias de desenvolvimento, $50 \mu \mathrm{m}$. B: feto com 45 dias de desenvolvimento, $50 \mu \mathrm{m}$. C: feto com 55 dias de gestação, $50 \mu \mathrm{m}$. D: feto com 65 dias de desenvolvimento $50 \mu \mathrm{m}$. E: gato com 6 meses pós-natal, $20 \mu \mathrm{m}$. F: gato com 1 ano de idade, $50 \mu \mathrm{m}$. Legenda: CE - célula endotelial, CT- corpúsculo tímico, V- Vaso, seta - célula endotelial, * : Célula migratória.

Figura 7 Fotomicrografias da localização da proteína Flt-1 em timos de gatos. A: feto com 35 dias de desenvolvimento,50 $\mu \mathrm{m}$. B: feto com 45 dias de desenvolvimento, $50 \mu \mathrm{m}$. C: feto com 55 dias de gestação, $50 \mu \mathrm{m}$. D: feto com 65 dias de gestação, $50 \mu \mathrm{m}$, E: 6 meses pós-natal, $20 \mu \mathrm{m}$. F: 1 ano de idade, $50 \mu \mathrm{m}$. Legenda: V: Vaso; CE: Célula epitelial; Seta: Célula endotelial. 
Figura 8 Fotomicrografias do timo de gato. A- Fragmento de órgão aos 35 dias de gestação. Observam-se lóbulos em processo de formação e grande presença de tecido conjuntivo interlobular. Barra: $100 \mu \mathrm{m}$. BFragmento de órgão aos 45 dias gestacionais. Maior organização e desenvolvimento da lobulação tímica característica. MEV. Barra: 200 $\mu \mathrm{m}$.

TESE para fazer lista.doc - _Toc323147977 Figura 10 Fotomicrografias do timo de feto de gato de aproximadamente 45 dias de gestação. É evidente a presença de linfócitos de diferentes graus de maturação, ou seja, timócitos de diferentes tamanhos, envoltos por prolongamentos de células reticulares epiteliais e fibras de tecido conjuntivo em região medular. MEV. A- Barra: $10 \mu \mathrm{m}$. B- Barra: $10 \mu \mathrm{m}$. C- Barra: $10 \mu \mathrm{m}$.

Figura 11 Fotomicrografias do timo de feto de gato de aproximadamente 55 dias de gestação. Células epiteliais estão densamente empilhadas, deixando pouco espaço extracelular. Estas células possuem extensões citoplasmáticas curtas. MEV. Figuras A e B - Barra: $10 \mu \mathrm{m} . . .85$

Figura 12 A: Fotomicrografias do timo de feto de gato de aproximadamente 55 dias de gestação. Um complexo linfoepitelial parecido com o "thymic nurse cell" (TNC) onde ocorre a diferenciação dos linfócitos T, esta diferenciação é demonstrada pela expressão de microvilos nos timócitos. Na figura B observa-se um timócito, expressando os microvilos, que está entrando ou saindo do complexo TNC. MEV. A e B: Barra $3 \mu \mathrm{m}$.

Figura $13 \mathrm{~A}$ e B: Fotomicrografias do timo de feto de gato de aproximadamente 6 meses pós-natal. Evidenciando corpúsculos tímicos (CT). Na figura C observam-se vasos (V) tortuosos do parênquima tímico, animal com 6 meses de idade pós-natal. A, B e C: Barra $30 \mu \mathrm{m}$. Na figura $\mathrm{D}$ evidenciam-se adipócitos (Ad) e aglomerados de timócitos a esquerda da foto, seta indica a cápsula tímica, animal acima de 1 ano de idade. MEV. Barra: $20 \mu \mathrm{m}$. 


\section{LISTA DE GRÁFICOS}

Gráfico 1 Parâmetros macroscópicos (espessura, comprimento e largura) e microscópicos, variáveis estereológicas, no timo de gatos em diferentes faixas etárias, machos e fêmeas. Variáveis: volume; comprimento do vaso (L); densidade do comprimento do vaso $\left(L_{v}\right)$; densidade de superfície de área $\left(\mathrm{S}_{\mathrm{v}}\right)$; superfície de área (S); densidade numérica vascular $\left(\mathrm{N}_{\mathrm{v}}\right)$; número total de vasos no órgão (N). A - Volume $\left(\mathrm{cm}^{3}\right)$. B - Espessura (cm). C - Comprimento (cm). D - Largura (cm). $\mathbf{E}-\mathrm{L}(\mathrm{mm})$. $\mathbf{F}-\mathrm{L}_{\mathrm{v}} \cdot \mathbf{G}-\mathbf{S}_{\mathrm{v}} \cdot \mathbf{H}-\mathbf{S}\left(\mathrm{mm}^{2}\right)$. I - $\mathrm{N}_{\text {(vasc) }}$. $\mathbf{J}$

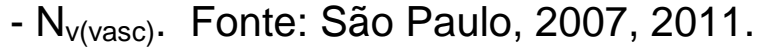

Gráfico 2 Expressão relativa do mRNA do VEGF (A), Flt-1 (B) e KDR (C) no timo de gato ao longo de seu desenvolvimento $(35,45,55,65$ dias de gestação), maturação (6 meses pós-natal) e fase de involução (1 ano de idade). Gráficos representam a média \pm EPM de três animais. Letras diferentes correspondem a diferenças significativas $(p<0,05)$ entre os grupos. 


\section{LISTA DE QUADROS}

Quadro 2 - Sequência dos oligonucleotídeos iniciadores utilizados para a amplificação do, VEGF, KDR, Flt-1, GAPDH, $\mathbf{S}=$ sense, $\mathbf{A}=$ antisense, $\mathbf{P}=$ probe.

Quadro 3 - Anticorpos primários utilizados na reação de imuno-histoquímica. 


\section{LISTA DE TABELAS}

Tabela 1 - Valores das variáveis, volume referência $\left(\mathrm{V}_{(\text {ref })}\right)$, comprimento, espessura e largura do timo em machos e fêmeas nos diferentes grupos etários. São Paulo - 2007; 2011.

Tabela 2 - Valores das variáveis densidade de comprimento do vaso (Lv), comprimento do vaso (L), densidade de superfície de área (Sv), superfície de área (S), estimação da densidade numérica vascular $\left(\mathrm{N}_{\mathrm{v}(\text { vasc })}\right)$, número total de vasos no órgão $\left(\mathrm{N}_{\text {(vasc) }}\right)$, do timo em machos e fêmeas nos diferentes grupos etários - São Paulo - 2007; 2011.........73 


\section{SUMÁRIO}

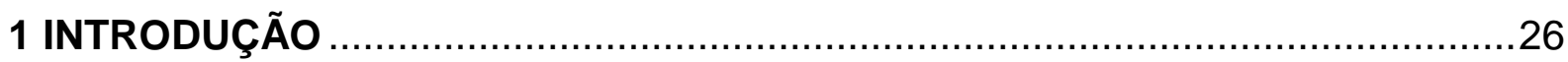

2 OBJETIVOS

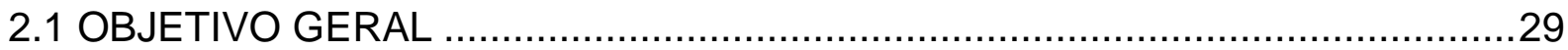

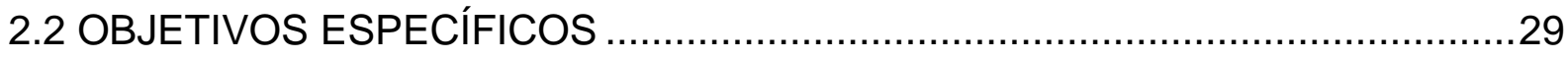

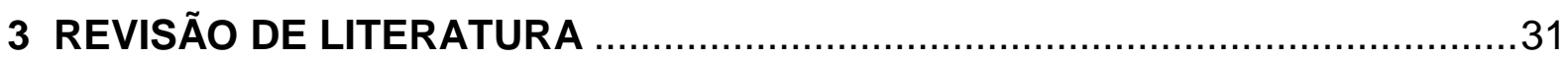

3.1 TOPOGRAFIA E ESQUELETOPIA DO TIMO ..............................................

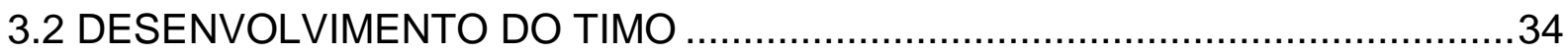

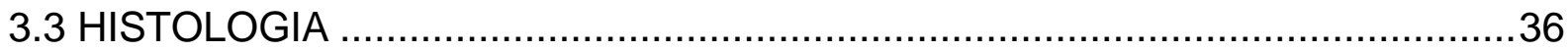

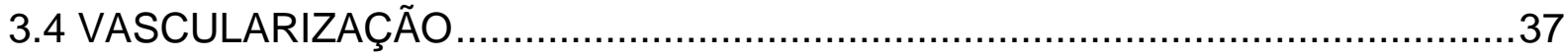

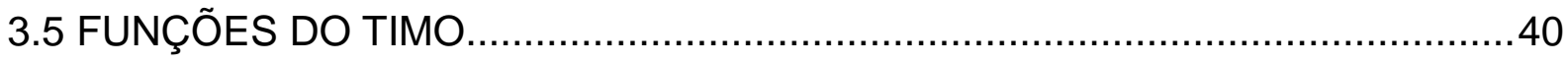

3.6 ORIGEM DOS LINFÓCITOS E DIFERENCIAÇÃO DOS LINFÓCITOS T...........41

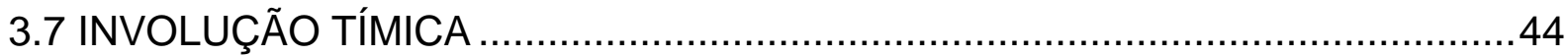

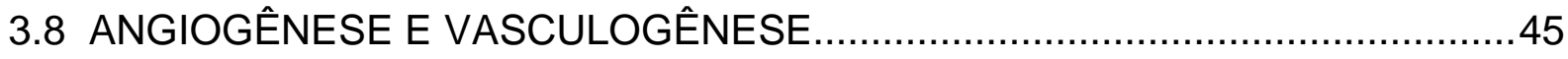

4 MATERIAL E MÉTODO

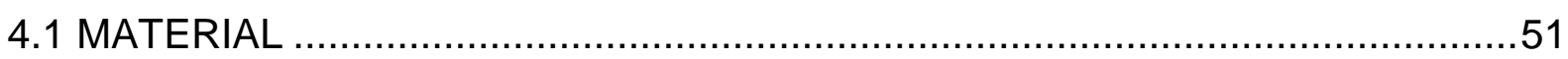

4.2 MÉTOdO PARA PREPARAÇÃO DO MATERIAL PARA ESTEREOLOGIA .......51

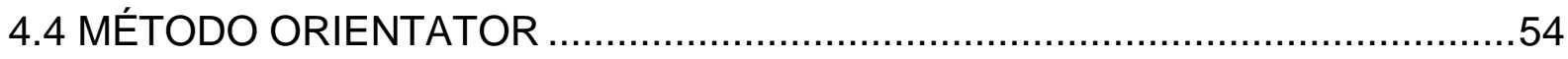

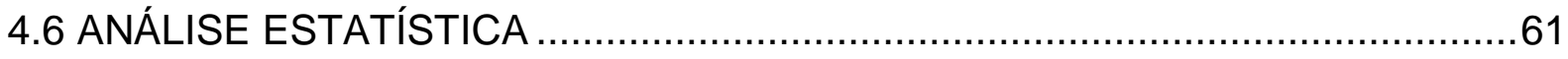

4.7 PREPARAÇÃO DO MATERIAL PARA PCR EM TEMPO REAL........................62

4.8 PROCESSAMENTO DO MATERIAL PARA IMUNO-HISTOQUÍMICA ..............66

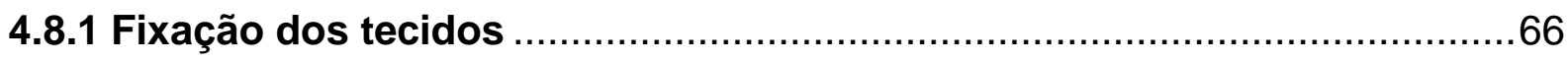

4.8.2 Tratamento das lâminas com 3-aminopropyltrietroxy-silano (APES)........66

4.8.3 Imuno-histoquímica do vegf e seus receptores (Flt-1 e KDR) ..................67

5 RESULTADOS 
5.2 EXPRESSÃO RELATIVA DO mRNA DO VEGF E SEUS RECEPTORES (FIt-1 E

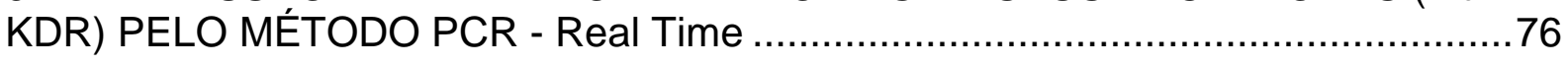

5.3 IMUNOLOCALIZAÇÃO DO VEGF E SEUS RECEPTORES (Flt-1 e KDR).........78

5.4 MICROSCOPIA ELETRÔNICA DE VARREDURA (MEV)..................................82

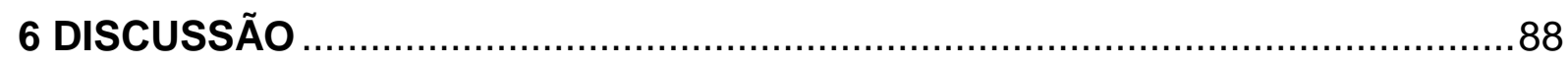

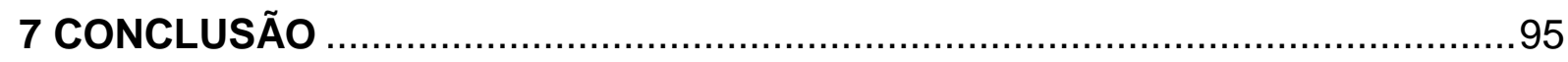

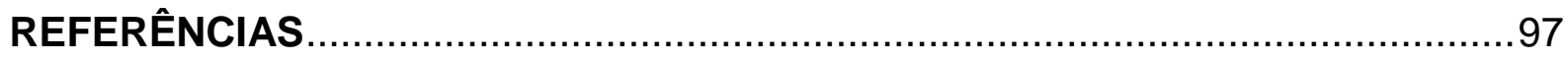


INTRODUÇÃO 


\section{INTRODUÇÃO}

O timo é um órgão linfático primário que desenvolve sua atividade em organismos jovens (KÖNIG; LIEBICH, 2004). As células $T$ iniciam seu desenvolvimento como precursoras na medula óssea, migram posteriormente para o timo, onde sofrem divisão, diferenciação e maturação em células T funcionais (BARDAYAN et al., 1999). A migração para os órgãos linfáticos secundários faz com que adquiram características novas e se transformem em células imunocompetentes (SILVA et al., 2001).

O desenvolvimento do timo ocorre de forma par desde o terceiro arco faríngeo, ao longo da traquéia em direção caudal, até o pericárdio (KÖNIG; LIEBICH, 2004). O timo deriva-se da terceira e da quarta bolsas faríngeas acompanhando os derivados paratireoideanos dessas mesmas bolsas. O broto tímico se separa dos derivados da paratireóide, ocupando parte do mediastino cranial, da entrada do tórax e da região cervical ventral (BANKS, 1992).

Durante o desenvolvimento do timo, ramos vasculares sanguíneos penetram no parênquima acompanhando os tecidos conjuntivos da cápsula, e formando um espaço de tecido conjuntivo perivascular (compartimento extraparenquimal) ao redor das veias (KATO, 1997). Os vasos sanguíneos do timo mostram uma arquitetura típica caracterizada por vasos de grande calibre, localizados na junção corticomedular, e uma fina rede de ramos e arcos de anastomose que se estendem para o córtex. Esta rede vascular que consiste de ramos e anastomoses de vasos sanguíneos possui a sua base molecular desconhecida (ANDERSON; ANDERSON; FARR, 2000).

A partir da puberdade o timo inicia um processo de involução (KÖNIG; BANKS, 1992; LIEBICH, 2004) e as primeiras modificações nos compartimentos do órgão se iniciam em proximidade direta com os vasos sanguíneos (BRELINSKA et al., 2008).

A involução gradual e contínua do timo é caracterizada pela diminuição do peso do órgão, perda dos linfócitos corticais, infiltração pelas células adiposas e aumento do número dos corpúsculos tímicos. Por fim, a infiltração de células adiposas substitui completamente o órgão (BANKS, 1992). 
A remoção do timo de animais adultos não produz resultados óbvios imediatos. Se, porém, os animais forem mantidos por vários meses após a operação, observa-se um declínio progressivo no número de linfócitos circulantes e na capacidade destes linfócitos montarem uma resposta imune mediada por células. A interpretação destes resultados sugere que embora o timo no adulto ainda seja funcional, existe um reservatório de células derivadas do timo que deve ser esgotado antes dos efeitos da timectomia tornarem-se aparentes (TIZARD, 2009).

Diversos experimentos têm revelado que o desenvolvimento normal de um indivíduo, e a manutenção das estruturas linfóides depende de um órgão linfóide específico quanto ao caráter precursor linfopoiético - o timo. Assim como, as respostas imunológicas naturais ou induzidas que estão de diferentes formas relacionadas às estruturas do sistema linfático, muitas vezes são intermediadas e coordenadas pelo timo (BOMBONATO, 1997). Um estudo quantitativo da vascularização tímica constitui ferramenta importante para o entendimento do comportamento vascular no órgão durante estágio de desenvolvimento e involução, questões que aparecem em períodos de adaptação, evolução ou doenças no organismo, necessitam de análises quantitativas para seu melhor entendimento (ANDERSEN; PAKKENBERG, 2003).

Os morfologistas estão tradicionalmente interessados na forma e composição de estruturas macro, meso, microscópico e ultraestrutural, por isso tem se beneficiado do uso de técnicas genéticas e moleculares que ajudam no esclarecimento de dúvidas, com isso melhorando as pesquisas biológicas e biomédicas (MAYHEW, 1992; ANDERSEN; PAKKENBERG, 2003; MANDARIM-DELACERDA, 2003).

Pelo timo ser considerado um órgão de elevada importância para o sistema imunológico de um indivíduo, o entendimento do processo de evolução e involução é indispensável e estudos mostram que estas duas fases estão relacionadas, além de outros fatores, com a vascularização do órgão.

Este trabalho tem o propósito de analisar se o padrão de crescimento vascular está relacionado com o desenvolvimento e a involução tímica. 
OBJETIVOS 


\section{OBJETIVOS}

\subsection{OBJETIVO GERAL}

Este trabalho tem o propósito de analisar se o padrão de crescimento vascular está relacionado com o desenvolvimento e a involução tímica. Para isso será realizado a quantificação da vascularização do timo de gatos recém-nascidos pela técnica estereológica, análise do parênquima tímico pela técnica de microscopia eletrônica de varredura e análise dos tipos celulares presentes em cada estágio etário. Também será comparada a expressão do sistema VEGF nas amostras dos timos de gatos em cada estágio etário.

\subsection{OBJETIVOS ESPECÍFICOS}

a) Estimar a densidade de comprimento do vaso;

b) Estimar o comprimento vascular;

c) Estimar a densidade de área;

d) Estimar a área de superfície;

e) Estimar a densidade numérica do vaso;

f) Estimar o número total de vasos;

g) Comparar os dados estereológicos com a faixa etária;

h) Estudar a expressão gênica e protéica do fator de crescimento vascular endotelial (VEGF) e seus receptores VEGFR-1 (Flt-1) e VEGFR-2 (KDR) no órgão. 
REVISÃO DE LITERATURA 


\section{REVISÃO DE LITERATURA}

O interesse dos pesquisadores pela morfologia desse órgão só surgiu a partir da caracterização e diagnóstico das doenças denominadas autoimunes, já que a maioria destas está de alguma forma vinculada ao timo (SILVA et al., 1994).

O sistema linfóide é composto de órgãos linfóides primários e secundários. A função da estrutura linfóide primária é a linfopoiese das linhagens de células B e T. Os órgãos linfóides primários são constituídos pela medula óssea, timo, e o fígado fetal. Em aves, a Bursa de Fabricius é o local de linfopoiese de células B. Os órgãos linfáticos secundários são os nódulos linfáticos, baço, e estruturas linfóides associadas com a superfície de mucosas e pele (HALLIWELL; GORMAN, 1989).

O timo é uma glândula endócrina indispensável para o desenvolvimento e subsequente maturação dos linfócitos. Numerosos estudos a respeito das funções tímicas levaram a descobertas de vários fatores hormonais tais como a timosina, fator sérico tímico e timopoetina (LIN LI et al., 2002a).

\subsection{TOPOGRAFIA E ESQUELETOPIA DO TIMO}

Em gatos o timo ocupa a região de mediastino, cranial ao coração e ventral a traquéia (Figura 1). Variando em tamanho com a idade, no neonato é maior e atinge o seu tamanho absoluto na puberdade. Em filhotes, se estende cranialmente à região torácica e caudalmente entre as veias braquiocefálica no nível da quinta e sexta cartilagem intercostal, onde repousa na superfície ventral do pericárdio. A região caudal possui o lóbulo direito menor que o esquerdo (HUDSON; HAMILTON,1993). 
Figura 1 - llustração demonstra a cavidade torácica de gato comos pulmões seccionados. Timo (seta preta); A: brônquios seccionados e vasos pulmonares; B: coração com pericárdio; *: nervo frênico; D: veia cava caudal; E: esôfago; F: aorta.

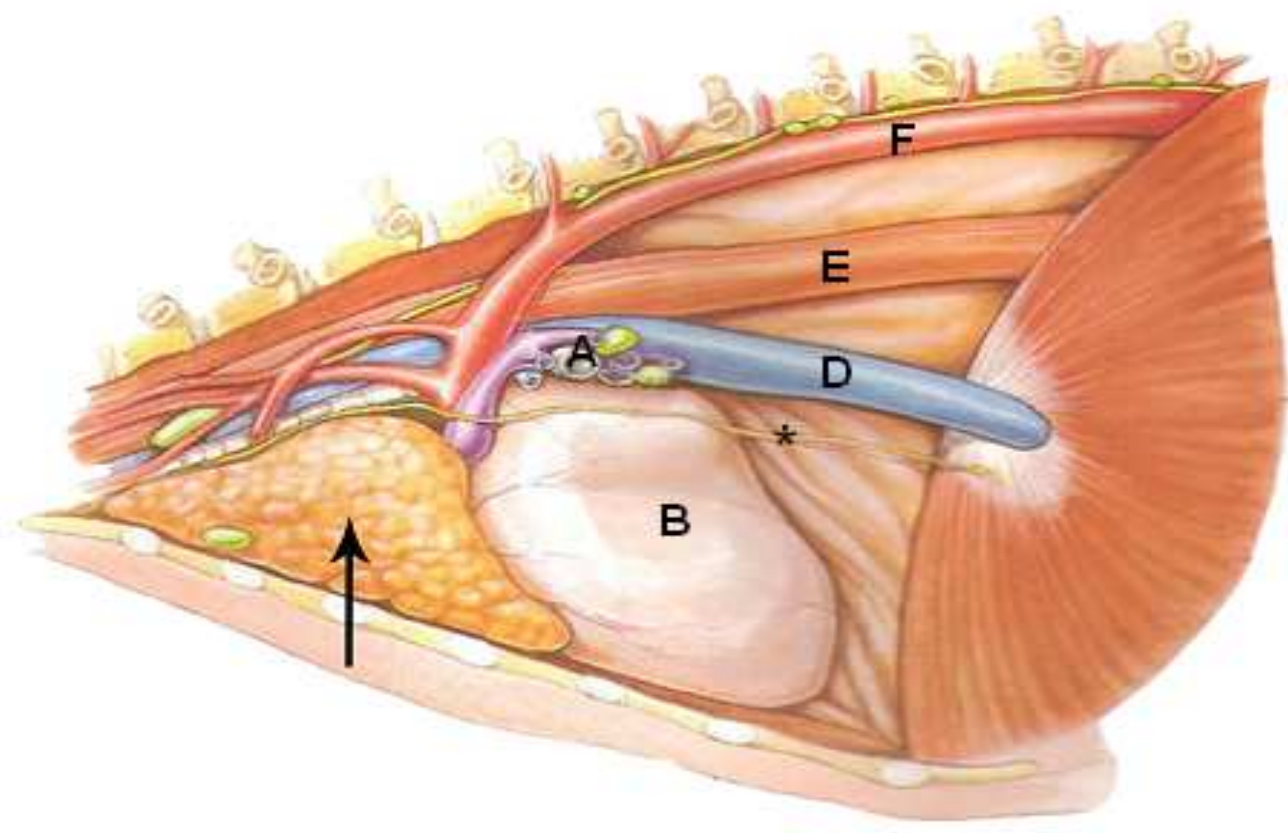

(Fonte: Hudson; Hamilton, 1993)

Daschinger (1983) descreveu o timo, do gato doméstico recém-nascido, macroscopicamente como um órgão visivelmente lobular e de coloração rosa-pálida que se estende cranialmente do manúbrio esternal pela abertura torácica cranial e ventralmente preenche dois terços do mediastino cranial. Observou também que 0 timo do gato possui uma porção par, pequena e comum em região cervical.

A forma deste órgão em gatos varia individualmente, mesmo entre irmãos e irmãs, muitas vezes consideravelmente (DASCHINGER, 1983).

Segundo Silva et al. (2001) a topografia do timo, em seu trabalho realizado em gatos, demonstrou a presença de duas porções, torácica e cervical, onde esta última, quando presente, mostrou-se fina e estreita, representando não mais que um quinto a um sexto do tecido tímico total e pronunciou-se cranialmente ao primeiro par de costelas.

Na superfície lateral da porção torácica esquerda mais dorsalmente e mais a esquerda localiza-se o nervo frênico. Caudalmente após a borda dorsal livre corre o 
nervo vago, mais à esquerda medialmente ao nervo vago, encontra-se o tronco braquiocefálico e a artéria subclávia esquerda. Dorso lateralmente a região esquerda da porção torácica encontra-se encoberta pelo lobo cranial do pulmão esquerdo (DASCHINGER, 1983).

A porção torácica direita é caracterizada como sendo uma porção menor e aproximadamente de formato triangular. Sua margem cranioventral convexa corre junto à A. torácica interna direita, a margem caudal côncava se encontra sobre o saco cranial do coração. A porção dorsal é limitada pela V. cava cranial e o N. frênico mais à direita. Lateralmente, a porção direita da porção torácica é completamente recoberta pelo pulmão torácico direito (DASCHINGER, 1983).

A transição da porção torácica para a porção cervical é demarcada por sulcos que são sobrepostos lateralmente por parênquima da porção torácica. Nestes sulcos encontram-se as A. e V. torácica interna descendente direita e a esquerda ventral ao esterno (DASCHINGER, 1983).

Após as duas porções torácicas craniais, surge a porção cervical que se inicia do terceiro par de costelas e avança cranialmente pela abertura torácica cranial, dorsalmente localiza-se a traquéia (DASCHINGER, 1983).

Em um trabalho realizado por Bombonato et al. (2001) com fetos de caprinos da raça Saanen observou-se a morfologia, topografia e esqueletopia do timo. Partindo da porção torácica, observaram o timo como uma massa única, de aspecto lobulado, com forma de trapézio irregular. Este envolve dorsalmente e, em parte, a face lateral esquerda do tronco braquiocefálico e ventralmente no limite deste tronco, preenchendo o espaço mediastinal cranial em sua porção pré-cardíaca, sobrepondose a uma porção do lobo cranial do pulmão esquerdo. Caudalmente observaram uma relação com a margem cranial do coração na sua face esquerda, sem, no entanto, cobri-la, e cranialmente alcança a transição cérvico-torácica, mantendo relação com a face interna do primeiro par de costelas e a artéria torácica interna esquerda. Em relação à projeção do timo ao gradil costal, especialmente à esquerda, devido a sua acentuada assimetria para este antímero, notaram que cranialmente, o limite deste se faz, em todos os casos, na altura da margem caudal do $1^{\circ}$ par de costelas e caudalmente atinge a margem cranial do $3^{\circ}$ ou $4^{\circ}$ par de costelas. 
Segundo um trabalho realizado por Agreste (2005) em fetos de cães foi descrito o timo como um órgão de coloração rósea com discretas lobulações nos filhotes, localizado no espaço mediastínico cranial, entre os dois pulmões, e sua extremidade caudal é moldado na superfície cranial do pericárdio, apresenta apenas parte torácica, sendo esta dividida incompletamente em um largo lobo direito e um pequeno lobo esquerdo, seu pólo cranial se localiza abaixo da traquéia e estende-se além do primeiro par de costelas.

A porção cervical do timo tipicamente se atrofia dentre os primeiros poucos meses de vida no cavalo, e, no entanto, não é comumente encontrada exceto no jovem potro. Ao contrário, o timo do bovino é identificável, mesmo no adulto, como uma estrutura pálida e lobulada. Os lobos cervicais direito e esquerdo são bem desenvolvidos em bezerros, e o timo é às vezes removido no abatedouro como "pão doce". O timo do porco é também muito desenvolvido até a idade de abate aproximadamente seis meses (SMALLWOOD, 1992).

\subsection{DESENVOLVIMENTO DO TIMO}

O epitélio do timo é derivado da camada endodérmica embrionária, com possível contribuição do ectoderma, por uma série de fases de diferenciação, cada qual deve ser completada com o objetivo de proporcionar um microambiente ótimo para o desenvolvimento e função tímica (BOCKMAN,1997).

Para Holländer et al. em 2006, a organogênese inicial do timo está intimamente ligada ao da glândula paratireóide, a qual tem sua origem na porção dorsal da terceira bolsa faríngea. Inicialmente formada como um primórdio comum, uma partição especial está presente entre esses dois órgãos durante esta fase de suas organogêneses. À primeira vista, se pensaria que o timo fosse constituído de células epiteliais, que tem origem endodermal e ectodermal, contudo experimentos em sistema aviário e mais recentemente em camundongos demonstraram claramente que as células do timo são de origem endodermal e que as células epiteliais ectodermais não contribuem para o desenvolvimento do timo.

A região significante de diferenciação do intestino anterior que segue com 0 objetivo de compreender o desenvolvimento do timo é a região faríngea. A faringe 
embrionária é importante para origem de muitos órgãos, incluindo a glândula tireóide e paratireóide, assim como o timo. Um entendimento desta associação íntima durante o desenvolvimento inicial é útil no entendimento de algumas deficiências que são observadas em associação com desenvolvimento de defeitos tímicos (BOCKMAN, 1997).

A proliferação das células que formam a terceira bolsa faríngea de cada lado produz um acumulo de epitélio que se estende ao mesênquima circundante. A porção dorsal de cada terceira bolsa faríngea se espessa em uma massa sólida que se torna a glândula paratireóide. As células remanescentes constituem o primórdio epitelial do timo. A terceira bolsa ventral é inicialmente uma cavidade, mas com o desenvolvimento conduz sua separação com a cavidade faríngea, e um corpo sólido é formado enquanto migra ventralmente e caudalmente (BOCKMAN,1997).

As suas células epiteliais formam uma base (forro) onde os linfócitos podem amadurecer e se desenvolver. Ainda há alguma confusão na ordem precisa dos eventos, mas parece que linfócitos derivados da medula óssea são atraídos pelo timo em desenvolvimento, o qual está sobre a influência de um fator (ou fatores) de constituição semelhante a um hormônio solúvel, um dos quais tem sido denominado timosina. As células que colonizam o timo não possuem características de células $B$ nem de células T. No entanto, após horas da chegada ao timo, os linfócitos, começam a expressar uma série de antígenos de superfície e receptores de uma maneira ordenada, conduzida por fatores solúveis liberados por células de suporte do timo (HALLIWELL; GORMAN, 1989).

Durante o desenvolvimento do timo, ramos vasculares sanguíneos penetram no parênquima profundo acompanhando os tecidos conjuntivos da cápsula e formam um espaço de tecido conjuntivo perivascular (compartimento extraparenquimal) ao redor das veias (KATO, 1997).

Segundo Silva et al. (2001) o timo apresenta seu mais alto grau de desenvolvimento durante a última fase do período pré-natal e no início de vida pósnatal. 


\subsection{HISTOLOGIA}

O timo tem origem embrionária dupla enquanto os outros órgãos linfóides possuem origem somente mesodérmica. Seus linfócitos se formam a partir de células mesenquimatosas, que invadem um espaço epitelial derivado do endoderma da terceira e, algumas vezes também da quarta bolsa faríngea (JUNQUEIRA; CARNEIRO, 1999).

Os elementos estromais de origem mesodérmica são capilares, septos e espaços perivasculares. Esses elementos separam o timo em pseudolóbulos. O espaço epitelial do timo e os espaços perivasculares estão sempre separados um do outro, por uma íntima camada celular epitelial com uma lâmina basal, que contribui para a barreira hematotímica (VON GAUDECKER, 1990).

O órgão é revestido por uma cápsula de tecido conjuntivo frouxo e tecido adiposo (MELO; LAGE, 1987; BANKS, 1992) do qual partem septos de tecido semelhantes, subdividindo o órgão em lóbulos. Esses septos se estendem para a junção cortico-medular (BANKS, 1992).

O tecido conjuntivo, que constitui esta cápsula apresenta uma preponderância de fibras colágenas sobre fibras elásticas, e tanto umas como outras, podem surgir em quantidade aumentada, formando espessamentos em pontos de junção da cápsula com a veia jugular ou outros vasos (MELO; LAGE, 1987).

O parênquima de cada lóbulo está subdividido em lóbulos que variam em tamanho, dependendo da espécie, de 5 a $15 \mathrm{~mm}$ de largura. $O$ tecido intersticial do parênquima contém poucas fibras de tecido conjuntivo reticular, muito dos quais podem estar concentrados ao redor dos vasos sanguíneos (GETTY, 1986).

O órgão é formado pelo córtex e pela medula bem definidos (BANKS, 1992). A parte mais externa de cada lóbulo, o córtex, é densamente infiltrada por linfócitos pequenos denominados timócitos. Os timócitos na medula não são tão densamente agrupados como no córtex, portanto, as células da medula são claramente visíveis (BANKS, 1992; TIZARD, 2009).

Investigações anteriores demonstraram a presença de vasos linfáticos na cápsula e no tecido conjuntivo interlobular. Em timo de camundongo foi registrado que os vasos linfáticos acompanham os vasos sanguíneos (ODAKA et al., 2006). 
Em um trabalho realizado por Odaka et al. (2006), os pesquisadores realizaram análise da expressão de marcadores de vasos linfáticos pela imunofluorescência com o objetivo de examinar a distribuição dos vasos linfáticos no timo de camundongos normais e concluíram que há a presença de capilares linfáticos por todo o timo.

Os vasos linfáticos são adaptados para carrear fluido, lipídios, e macromoléculas. Eles também servem como caminho de transito de linfócitos e células apresentadoras de antígenos, tais como células dendríticas. Comparados com os vasos sanguíneos, os vasos linfáticos podem ser morfologicamente idênticos pela presença de uma única camada fina celular endotelial não-fenestrada, a qual não possui células musculares lisas (ODAKA et al., 2006).

A característica definitiva do órgão é a presença de corpúsculos tímicos denominados antigamente de corpúsculos de Hassall, os quais estão presentes na medula. Sua função é desconhecida e são observados com frequência nos estágios avançados de involução do timo (BANKS, 1992).

Os corpúsculos tímicos consistem de poucas camadas de células epiteliais dispostas concentricamente. Em seu interior, estas células epiteliais estão mortas e normalmente a porção central consiste de queratina e material hialino (GETTY, 1986).

\subsection{VASCULARIZAÇÃO}

Durante o desenvolvimento do timo, ramos sanguíneos penetram no interior do parênquima acompanhando o tecido conjuntivo derivado da cápsula formando um espaço de tecido conjuntivo perivascular ao redor das veias (KATO, 1997).

As artérias penetram no timo pela cápsula, ramificam-se e aprofundam-se no órgão, seguindo os septos conjuntivos, originando as arteríolas que penetram no parênquima seguindo os limites entre a cortical e a medular. Estas arteríolas formam capilares que entram na cortical, ramificam-se e se anastomosam descrevendo um arco, dirigindo-se para a região medular, onde desembocam em vênulas. A região medular recebe outros capilares diretamente das arteríolas do limite córtico-medular. As vênulas da medular confluem para formar veias que penetram nos septos 
conjuntivos e saem do timo pela cápsula do órgão (JUNQUEIRA; CARNEIRO, 1999).

A irrigação do timo apresenta características peculiares, onde os capilares e pequenos vasos destinados ao órgão apresentam uma membrana basal, envolvida por uma camada de células epiteliais, que apesar de não ser totalmente contínua, atua como uma barreira; dificultando a passagem de antígenos ou macromoléculas do sangue para o interior do parênquima e, consequentemente, o seu contato com os linfócitos do órgão (SILVA et al., 2001). Esta barreira hematotímica que separa o sangue do parênquima tímico existe na região cortical do timo, e não na medular, e deve-se principalmente às junções oclusivas entre as células endoteliais não fenestradas dos capilares (JUNQUEIRA; CARNEIRO, 1999).

Daschinger em 1983 descreveu que o suprimento arterial de todo o timo de gatos recém-nascidos provem da $A$. torácica interna direita que se ramifica dando origem a um ramo caudal em direção ao timo torácico e um ramo craniomedial para o timo cervical.

Scala, Langella e Budetta (1984) após estudo do timo de patos domésticos evidenciaram as artérias lobares originando-se diretamente da artéria comum do nervo vago, correspondendo aos lobos tímicos, penetrando em número de uma a duas por lobo. Observaram também que a vascularização do órgão apresenta características particulares devido à morfologia, caracterizando os lobos como uma entidade anatômica isolada e com uma topografia peculiar, ocupando uma grande extensão da região cervical.

Com respeito às artérias tímicas, somente Versari (1897) descreveu as artérias tímicas inferior e média no homem e em outros mamíferos. Notou que não encontrou a artéria tímica surgindo da artéria carótida comum externa ou interna, embora o ramo descendente da artéria tireóidea superior vascularize a traquéia e o esôfago.

Segundo trabalho realizado por Bombonato et al. (2001), o timo como um todo recebe irrigação de vasos oriundos do tronco braquiocefálico, tronco bicarotídeo, artérias intercostais esquerdas, torácica interna esquerda, escapular dorsal esquerda, de ramos diretos e indiretos das artérias carótidas comuns esquerda e direita, das artérias tireóideas craniais e caudais esquerda e direita, 
tireóideas imas esquerda e direita, laríngeas esquerda e direita, faciais esquerda e direita, axilar esquerda e carótida externa esquerda.

Silva et al. (2001) observaram em seu trabalho realizado em gatos, SRD, adultos, ambos os sexos, que a maior contribuição vascular se deu através dos ramos fornecidos pela artéria torácica interna esquerda e do tronco braquiocefálico. Concluíram também que os ramos diretos destinados ao timo foram provenientes das artérias torácicas internas e carótidas comum direita e esquerda e dos troncos braquiocefálico e bicarotídico.

O suprimento sanguíneo do timo de porquinhos da índia e porcos foi estudado por Olson e Poste em 1973, utilizando carbono ou prata intravascular, demonstrando que estes animais possuem um sistema vascular mais extensivo que o do camundongo. Histologicamente, em seções seriadas, as artérias interlobulares foram vistas entrando na junção medular de dois ou mais lobos, e se subdivide em um número grande de ramos menores. Esses atravessam a medula ou correm ao longo da junção corticomedular. Elas então se angulam de modo repentino para dentro do córtex como fileiras paralelas de vasos de parede fina. Esses vasos que penetram, às vezes, se ramificam e variam de diâmetro, muitas vezes se tornam grandes vênulas antes de confluírem para o sistema de veias perilobulares descrito acima. Observaram também uma rede de veias ao longo da junção corticomedular a qual é acompanhada por artérias medulares.

Agreste (2005) realizou um estudo estereológico do timo em cães onde foram avaliados os aspectos quantitativos vasculares deste órgão e seus achados mostraram que o timo das fêmeas apresentou maior volume (Vref) e dimensões de tamanho que os machos; a densidade numérica vascular e o número total de vasos foram menores nos machos que nas fêmeas. Demonstrou também que as variáveis estereológicas e as variáveis, comprimento, espessura e largura tiveram aumento gradativo de acordo com as faixas etárias (30,40,50 e 60 dias de período gestacional), sendo que nas fêmeas os valores eram maiores que nos machos, com exceção da densidade de comprimento (Lv).

Barroso (2007) realizou um estudo estereológico do timo em gatos SRD (35, 45, 55 dias de período gestacional) onde as medidas estereológicas relativas à densidade numérica vascular $\left(\mathrm{Nv}_{(\mathrm{vasc})}\right)$ apresentaram-se maiores nas fêmeas, ocorrendo uma diminuição gradativa e o número total de vasos no órgão $\left(\mathrm{N}_{\text {(vasc) }}\right)$ 
apresentou valores maiores nos machos com uma diminuição gradual. A estimativa da densidade do comprimento do vaso (LV) e da densidade de superfície de área (Sv) apresentaram diminuição aos 45 dias de idade, e a densidade do comprimento do vaso (Lv) apresentou valor maior nos machos de 35 e 55 dias, enquanto que na densidade de superfície de área (Sv) os valores variaram entre os sexos.

\subsection{FUNÇÕES DO TIMO}

O sistema linfóide é composto de órgãos linfóides primários e secundários. A função da estrutura linfóide primária é a linfopoiese das linhagens de células B e T. Os órgãos linfóides primários são constituídos pela medula óssea, timo, e o fígado fetal. Em aves, a Bursa de Fabricius é o local de linfopoiese de células B. Os órgãos linfáticos secundários são os nódulos linfáticos, baço, e estruturas linfóides associadas com a superfície de mucosas e pele (HALLIWELL; GORMAN, 1989).

Em condições fisiológicas o timo possui uma barreira antigênica bloqueando a entrada de antígenos, prevenindo a estimulação de uma resposta imune no timo. Certas doenças tais como a cinomose canina, o antígeno viral tem acesso ao tecido tímico e, na fase de recuperação de infecção, podem estimular a formação de um centro germinal na medula (GERSHWIN; KRAKOWA; OLSEN, 1995).

A função do timo é educar e provir à circulação e aos órgãos linfóides secundários linfócitos T. Aos 40 dias de gestação em gatas prenhes, os linfócitos povoam o timo, onde desenvolvem a capacidade de distinguir o próprio do não próprio. Os órgãos linfóides secundários acolhem os linfócitos T funcionais, em gatos isto ocorre antes do nascimento (HUDSON; HAMILTON, 1993).

O timo é capaz de secretar hormônios e funcionar como uma glândula endócrina. As células epiteliais tímicas liberam vários hormônios polipeptídicos que devem restaurar parcialmente a função tímica. Eles incluem as moléculas, chamadas de timosinas, timopoietinas, fator humoral tímico, timulina e timoestimulantes. Os mais importantes são a timosina que age sobre a medula óssea fazendo com que células precursoras ali localizadas adquiram algumas características de célula $\mathrm{T}$, as timopoietinas que provocam a diferenciação de células precursoras de células $\mathrm{T}$ e estimulam a função de células $\mathrm{T}$ e o fator tímico 
humoral e a timulina que restauram parcialmente a função de células $T$ em animais timectomizados (TIZARD, 2009).

Em um trabalho realizado por Lin Li et al. em 2002a, em camundongos infectados com Hepatite viral tipo $B$, provaram que o hormônio tímico denominado Timosina a 1 sintetizada quimicamente reabastece a produção de anticorpo mediada por célula $\mathrm{T}$ e acelera o restabelecimento e maturação dos timócitos e concluíram que o restabelecimento de alguns dos defeitos no sistema de defesa do hospedeiro facilita a eliminação do agente infeccioso.

\subsection{ORIGEM DOS LINFÓCITOS E DIFERENCIAÇÃO DOS LINFÓCITOS T}

Embora os antígenos sejam capturados e processados pelos macrófagos, células $B$ e células dendríticas, uma resposta imune é, na verdade, montada por células chamadas linfócitos. Os linfócitos são as pequenas células redondas que predominam nos órgãos, tais como o baço, os linfonodos e o timo. Os linfócitos possuem receptores para antígenos e podem, portanto, reconhecer e responder ao antígeno apresentado. Os linfócitos são eventualmente responsáveis pela produção de anticorpos e pela destruição de células anormais. Essas respostas ocorrem dentro dos órgãos linfóides, o que proporciona um ambiente para a interação eficiente entre os linfócitos, células apresentadoras de antígenos e antígenos estranhos.

No feto muito jovem, as células precursoras linfóides são inicialmente produzidas no omento primitivo, no fígado e no saco vitelino. Nos fetos mais velhos e nos adultos, a medula óssea é a principal fonte de linfócitos (TIZARD, 2009).

A medula óssea desempenha múltiplas funções nos mamíferos adultos. Em todos os mamíferos, a medula óssea é um órgão hematopoiético que serve como origem de todas as células sanguíneas, incluindo linfócitos e células dendríticas. Em alguns mamíferos, como os primatas, ela também age como órgão linfóide primário no qual alguns linfócitos amadurecem. Como o baço, o fígado e os linfonodos, a medula óssea contém muitos macrófagos e conseqüentemente remove partículas de sangue. Finalmente, é uma fonte importante de anticorpos. Em virtude dessas funções múltiplas, a medula óssea se divide em dois compartimentos, um 
compartimento hematopoiético e um vascular. Esses compartimentos se alternam como fatias de bolo, nas áreas em forma de cunha dentro dos ossos longos. $O$ compartimento hematopoiético contém precursores de todas as células sanguíneas, como dos macrófagos, das células dendríticas e dos linfócitos, e encontra-se envolvido por uma camada de células adventícias. Nos animais mais idosos, essas células adventícias podem ficar tão carregadas com gordura que a medula pode ter uma aparência amarela gordurosa. O compartimento vascular consiste em seios sanguíneos revestidos por células endoteliais e atravessados por células reticulares e macrófagos (TIZARD, 2009).

O timo é o único órgão hematopoiético que recruta células precursoras hematopoiéticas do sangue e, ao mesmo tempo, exclui células maduras de entrarem no timo. Este recrutamento é contínuo pelo timo não suportar células-tronco hematopoiéticas de auto-renovação. O requerimento para importação contínua de precursores hematopoiéticos e o processo de diferenciação intratímico de célula T estão intrinsecamente ligados ao processo de desenvolvimento do timo (BOEHM; BLEUL, 2006).

As células $\mathrm{T}$ iniciam seu desenvolvimento como precursoras na medula óssea. Essas células migram para o timo, onde se dividem se diferenciam, e se maturam em células $T$ funcionais. A maioria dos timócitos (95-99\%) morre no curso deste processo, e somente poucos deixam o timo como células maduras (BARDAYAN et al.,1999).

As células T são derivadas de precursores hematopoiéticos, os quais, após entrarem no timo, são submetidos a um programa de proliferação, diferenciação, e seleção para produzirem uma população de células $T$ funcionalmente competentes (ANDERSON et al., 1996). Durante a colonização inicial, a qual precede a vascularização, os precursores dos vasos deixam os vasos faríngeos adjacentes e cruzam o mesênquima peritímico e a membrana basal que circunda o epitélio rudimentar para adentrar ao timo (WILKINSON; OWEN; JENKINSON, 1999).

A diferenciação dessas células ocorre ao longo de sua migração no microambiente estritamente compartimentalizado tímico, que é formado de células de diferentes tipos como células epiteliais, macrófagos, células dendríticas, fibroblastos, e componentes da matriz extracelular, e o processo de desenvolvimento das células $T$ é comumente descrito como um fluxo linear sucessivo, por 
compartimentos cada vez mais diferenciados. Supondo então que os timócitos em estágios diferentes de maturação estão situados dentro de porções distintas do órgão (SOLAROVIĆ; LALIĆ; LEPOSAVIĆ, 2004).

O desenvolvimento das células $\mathrm{T}$ intratímicas requer um microambiente estromal íntegro no qual as células epiteliais tímicas constituem a maior parte (RITTER; CRISPE, 1992; BLEUL et al., 2006). O córtex fornece o microambiente necessário para a seleção positiva de timócitos imaturos e a região medular para seleção negativa de células T auto-reativas (RITTER; CRISPE, 1992; BOEHM; BLEUL, 2006).

Uma hipótese é que a noradrenalina pode influenciar na maturação intratímica da célula $T$, não somente diretamente via $\beta$-adrenoreceptores nas células nãolinfóides tímicas, mas também proporcionando assim um microambiente benéfico para a diferenciação e maturação das células T (KURZ et al., 1997). Dados indicam que a concentração intratímica de noradrenalina aumenta progressivamente do período neonatal até o 60º pós-natal (LEPOSAVIĆ et al., 1992).

O efeito do tratamento de propranolol na maturação das células $T$ intratímicas em ratos em diferentes estágios de maturação sexual pode ser explicado por dados que demonstra o perfil fenotípico dos timócitos de ratos controle imaturo, o perfil destes é significantemente diferente do perfil dos ratos adultos, a densidade dos $\beta$ adrenoreceptores e a concentração da sua noradrenalina ligante endógena estavam significantemente mais baixas no timo dos ratos imaturos sexualmente do que no timo de ratos adultos (MARCHETTI; MORALE; PALLETIER, 1990; LEPOSAVIĆ et al., 1992).

Entre as novas células produzidas, a maioria morre logo, enquanto as sobreviventes (cerca de $5 \%$ do total nos roedores e cerca de $25 \%$ nos bezerros) permanecem por 4 a 5 dias antes de sair e colonizar os órgãos linfóides secundários (SURHT; SPRENT, 1994). As células T liberadas do timo para a circulação devem ser capazes de participar de respostas imunes, ainda que respondam fortemente aos constituintes corpóreos normais. Isso é obtido por uma seleção positiva e negativa de células. Assim, a apoptose que ocorre na medula do timo resulta na destruição seletiva daqueles timócitos que reconhecem o complexo de peptídeo MHC de classe II com alta afinidade e que poderiam potencialmente causar uma doença auto-imune, caso escapassem para a periferia. A seleção de timócitos pode 
ocorrer, em parte, dentro das células-guardiãs. As células guardiãs tímicas podem englobar até 50 timócitos em um período e eventualmente liberá-los ileso (TIZARD, 2009).

\subsection{INVOLUÇÃO TÍMICA}

Diversos trabalhos comprovam que o timo possui uma importância significativa no desenvolvimento e manutenção de um sistema imunológico competente, e que o processo de involução é acelerado após a puberdade, quando ocorre uma elevação dos esteróides sexuais no sangue (WINDMILL; LEE, 1998).

A duração de vida do timo é curta, o processo de involução pode variar de meses a anos dependendo da espécie. Como as células T são as células centrais na resposta imune, existe a preocupação de que a ausência de um timo funcional em um adulto possa causar inabilidade em responder a infecções. No entanto, as células T possuem vida longa e se auto-replicam. Ausência total do timo no neonato é um achado clínico incomum e invariavelmente fatal. Existem, contudo, exemplos no qual danos induzidos por vírus ao timo em animais jovens comprometem severamente o sistema imune pela destruição das células $\mathrm{T}$ em desenvolvimento. Dois exemplos detalhados disto tem sido a destruição vista na infecção pela parvovirose canina e leucemia felina induzida por vírus (HALLIWELL; GORMAN, 1989).

Com o avançar da idade do animal, há uma perda progressiva de tecido, o qual é substituído por gordura, contudo, o timo idoso ainda contém ilhas de tecido linfóide, incluindo córtex e medula, e é funcionalmente ativo (TIZARD, 2009).

Bar-Dayan et al. (1999) também confirmam que vários efeitos hormonais e neuroendócrinos (ex. glicocorticóides, hormônio do crescimento, insulina, etc) fazem parte da regulação da involução tímica (BAR-DAYAN et al., 1999). O timo começa a involuir quando o gato alcança a maturidade sexual e, no gato adulto, se apresenta apenas como um resquício em região de mediastino cranial (HUDSON; HAMILTON, 1993). 
Infecções recorrentes em filhotes podem levar a atrofia tímica prematura. Isto ocorre devido à depleção de células T nos órgãos linfóides secundários e no timo. A causa mais comum de atrofia tímica em gatos é a infecção pelo Vírus da Leucemia Felina (FeLV). Na necropsia, pouco ou nenhum tecido tímico é encontrado nos filhotes. FeLV também causa linfoma tímico, que é comumente observado em gatos de 1 a 2 anos de idade. Nestes casos o timo aumenta de volume, formando uma massa que comprime o pulmão e o coração contra a região dorsocaudal do tórax, ocasionando angústia respiratória para o animal (HUDSON; HAMILTON, 1993).

Em um trabalho realizado em galinhas por Melo e Lage (1987) observaram que os agentes depressores do timo, orgânicos ou não, isto é, produzidos pelo animal ou agindo sobre ele por interferência externa, provocam uma regressão prematura na estrutura histológica do órgão.

Em um estudo realizado por Bar-Dayan et al. (1999), onde compararam a proliferação e apoptose dos timócitos em diferentes partes do timo de camundongos fêmeas, no início e após a rápida fase de declínio da celularidade tímica cortical, concluíram que após a involução do timo há uma mudança no balanço entre a proliferação e apoptose especialmente no córtex tímico. Há uma redução no índice de proliferação e uma elevação no índice de apoptose do córtex tímico no camundongo adulto comparado ao camundongo jovem. Esta mudança pode ser considerada pela redução da celularidade do córtex tímico durante a involução tímica.

Em estudos realizados por Windmill, Meade e Lee em 1993 e Windmill e Lee em 1998 observaram que os efeitos da castração em ratos com idade prépuberdade e adultos tem um efeito benéfico sobre o sistema imune, aumento do crescimento tímico e o processo de involução retardada.

\subsection{ANGIOGÊNESE E VASCULOGÊNESE}

A angiogênese é caracterizada pela formação de uma nova rede vascular a partir de vasos pré-existentes. Em geral, o processo angiogênico é iniciado pela ação de fatores de crescimento, os quais atuam aumentando a permeabilidade dos 
vasos, estimulando a degradação proteolítica da matriz extracelular através de proteases específicas e favorecendo a proliferação de células endoteliais. O declínio no número de vasos sanguíneos no órgão reflete a diminuição de estímulos angiogênicos. Para este processo é primordial a presença do fator de crescimento endotelial vascular (VEGF - Vascular Endothelial Growth Factor) (RISAU, 1997).

Os processos de vasculogênese são caracterizados pelo desenvolvimento capilar a partir de diferenciação de células precursoras de origem mesenquimal, sendo um processo envolvido na formação dos vasos ocorrida durante a embriogênese (CAMPOS, 2005). Os fatores envolvidos neste processo são os mesmos fatores angiogênicos que também contribuem para vários processos fisiológicos e patológicos, incluindo desenvolvimento embrionário, cicatrização, crescimento e processos metastáticos de tumores, retinopatia diabética, revascularização de isquemia do miocárdio, formação do corpo lúteo, crescimento do endométrio, implantação do embrião e placentação. A angiogênese fisiológica e a patológica compartilham três aspectos muito importantes: proliferação, migração e invasão através da matriz extracelular e habilidade de acessar a rede vascular préexistente em busca de suprimento sanguíneo (ZYGMUNT et al., 2003).

$O$ processo de vasculogênese no timo ocorre durante o seu desenvolvimento embriológico, onde os vasos sanguíneos penetram no interior do parênquima acompanhando o tecido conjuntivo derivado da cápsula, formando espaços perivasculares ao redor dos vasos (KATO, 1997).

O desenvolvimento do sistema vascular é um dos eventos iniciais na organogênese. Os vasos sanguíneos iniciais do embrião e do saco vitelino em mamíferos se desenvolvem por agregação dos angioblastos, formando um plexo vascular primitivo, denominado vasculogênese. Este plexo é submetido a vários processos de remodelamento, onde ocorrem crescimento, migração e germinação que lideram o desenvolvimento de um sistema circulatório funcional, denominado angiogênese (COULTAS; CHAWENGSAKSOPHAK; ROSSANT, 2005). 


\subsubsection{Fator de Crescimento Vascular Endotelial (VEGF) e seus receptores}

O fator de crescimento vascular endotelial (VEGF) recebeu essa denominação no final da década de 1980. Inicialmente descrito como fator de permeabilidade vascular, ele foi isolado pela primeira vez em líquido ascítico de cobaias em 1983 (SENGER et al., 1983). Posteriormente foi isolado e purificado a partir de meio de cultura de células foliculares da pituitária de bovinos (FERRARA; HENZEL, 1989).

Além dos efeitos angiogênicos e de permeabilidade vascular, outras pesquisas sugerem que o VEGF tem efeitos pró- inflamatório e neuroprotetor (FERRARA et al.,1992). É um mitógeno específico para células endoteliais, estimulando a proliferação (DULL et al., 2001; LANG et al., 2001) e migração (BERNATCHEZ; SOKER; SIROIS, 1999) destas células, além de regular o desenvolvimento vascular sob condições normais (CAO et al., 2004) e patológicas

O VEGF desempenha importante papel regulador no desenvolvimento vascular fisiológico, sendo que tanto a diminuição nos seus níveis quanto a sua ausência provocam danos na formação vascular sistêmica. Assim sendo, outras funções fisiológicas que dependem de angiogênese são prejudicadas quando da supressão ou ausência de VEGF, como reparação tecidual de feridas (NISSEN et al., 1998), crescimento ósseo (GERBER et al., 1999) e ovulação (FERRARA et al., 1998).

O VEGF é uma glicoproteína homodimérica (FERRARA, 2004), codificada por um único gene, cuja expressão pode ser regulada por alterações nos níveis de oxigênio tecidual (CAO et al., 1996), e com habilidade de promover o crescimento das células endoteliais derivadas de artérias, veias e linfáticos (FERRARA, 2004).

Em seres humanos, existem pelo menos oito isoformas do VEGF-A (VEGF121, VEGF145, VEGF148, VEGF165, VEGF165b, VEGF183, VEGF189 e VEGF206) que são geradas por derivação alternativa de um único gene. A nomenclatura utilizada para nomear as diferentes isoformas baseia-se na quantidade de aminoácidos que cada molécula de proteína secretada possui (BATES; HARPER, 2002; LANGE et al., 2003). A quantidade de aminoácidos define características de cada molécula como, por exemplo, a capacidade de ligação a 
heparina e sua solubilidade (PARK; KELLER; FERRARA, 1993; POLTORAK et al., 1997).

O VEGF age através dos receptores VEGFR-1/Flt-1 (Fms-like tyrosine kinase - 1; DE VRIES et al., 1992) e o VEGFR-2/KDR (Kinase insert domain containing region) (TERMAN et al., 1992). São receptores tirosina-quinase (RTKs) caracterizados por possuírem sete domínios imunoglobulina - miméticos em sua porção extracelular, uma região transmembrânica única e uma seqüência tirosinaquinase interrompida pelo domínio de inserção a quinase em sua porção intracelular (SHIBUYA et al., 1990). O VEGFR-3/FIt-4 (Fms-like tyrosine kinase - 4) (KAIPAINEN et al., 1995), outro membro da mesma família de RTKs age como receptor dos VEGF-C e VEGF-D (KARKHAINEN et al., 2002). Estes receptores são expressos em células endoteliais, mas alguns outros tipos celulares podem expressar um ou ambos os receptores. O VEGF se liga ao Flt-1 com uma constante de dissociação (Kd) de aproximadamente 10-20pM (DE VRIES et al., 1992). Entretanto, o KDR tem uma menor afinidade com o VEGF, a Kd é estimada em aproximadamente 75125pM (TERMAN et al., 1992).

Uma importância crítica do VEGF na angiogênese foi demonstrada estudando-se ratos, nos quais a deleção de ambos ou um único alelo do VEGF é letal durante o desenvolvimento fetal devido à interrupção da angiogênese embrionária; sua expressão aumentada de maneira anormal também induz a morte fetal, devido a hiper-vascularização e tecidos aumentados (STOUFFER et al., 2001).

Quando realizada uma deleção dos genes do Flt-1 e KDR em camundongos homozigotos os efeitos também foram letais. Enquanto os camundongos nocaute para o KDR falharam na formação de células endoteliais e seus precursores, os camundongos nocaute para o Flt-1 formaram células endoteliais, mas a formação da rede vascular foi anormal (FONH et al., 1995; SHALABY et al., 1995).

O KDR é expresso principalmente em células endoteliais angiogênicas e medeia os efeitos do VEGF de proliferação e migração. O Flt-1 participa da formação do arranjo da rede vascular (BOONYAPRAKOB et al., 2003), além de ser expresso em células endoteliais proliferativas e quiescentes (BERISHA et al., 2000). Entretanto algumas isoformas do VEGF-A se ligam seletivamente as neurofilinas NP-1 (VEGF165) e NP-2 (VEGF165 e VEGF145) outro tipo de receptores transmembrânicos, primeiro identificados no crescimento neuronal como mediadores 
do controle da orientação axonal (STOUFFER et al., 2001), e considerados coreceptores responsáveis por aumentar a afinidade entre o VEGF e o KDR (JUSSILA; ALITALO, 2002).

A expressão do VEGF é regulada por vários fatores. A hipóxia é um dos mais potentes estimuladores do VEGF (SHARKEY et al., 2000). Recentemente foi mostrado que no útero de ratos o estradiol induz a produção de VEGF via indução da produção de HIFa (fator induzido por hipóxia) e o recrutamento dessa proteína para promover a indução do VEGF (KAZI et al., 2005).

Outros fatores que regulam a expressão do VEGF são o TNFa (fator de necrose tumoral), as citocinas, TGF- $\alpha$ e $\beta$ (fator de crescimento tumoral $\alpha$ e $\beta$ ), fator de crescimento epidermal, interleucinas (ROBINSON; STRINGER, 2001). O bFGF (fator de crescimento fibroblástico) também modula a expressão gênica do VEGF e seus receptores KDR e Flt-1 (GABLER at al., 2004). 
MATERIAL E MÉTODO 


\section{MATERIAL E MÉTODO}

\subsection{MATERIAL}

Para realização desta pesquisa foram coletados 72 timos provenientes de fetos mortos naturalmente oriundos de cesariana e animais com até 1 ano de idade que vieram à óbito. Os timos foram subdivididos em diferentes grupos etários de aproximadamente 35, 45, 55 e 65 dias de gestação, 6 meses e 1 ano de idade que foram destinados ao estudo da imunohistoquímica e PCR contendo 6 animais em cada grupo. E animais com aproximadamente 65 dias de gestação, 6 meses e 1 ano pós-natal de gatos domésticos, foram destinados ao estudo da estereologia, com 6 animais em cada grupo. E foram destinados para a técnica de microscopia eletrônica de varredura (MEV) timos de aproximadamente 35, 45, 55 e 65 dias de gestação, 6 meses e 1 ano de idade com 2 animais em cada grupo. Os gatos foram oriundos do Hospital Veterinário da Faculdade de Medicina Veterinária e Zootecnia da Universidade de São Paulo - HOVET-FMVZ-USP, e todos os procedimentos experimentais foram aprovados pela Comissão de Ética no Uso de Animais desta faculdade.

\subsection{MÉTODO PARA PREPARAÇÃO DO MATERIAL PARA ESTEREOLOGIA}

Para realização desta técnica foram utilizados gatos com aproximadamente 65 dias de gestação, filhotes de 6 meses e adultos com1 ano de idade, com 6 animais em cada grupo. Os timos de fetos de 35,45 , e 55 dias de gestação já estavam prontos, pois foram utilizados na realização do trabalho de mestrado.

Após o óbito a cavidade torácica foi exposta pela incisão nas articulações costo-vertebrais proporcionando a localização dos principais vasos arteriais e venosos do tórax. A perfusão pela aorta foi feita com solução salina tamponada fosfatada (PBS) a $0,1 \mathrm{M}$ e pH 7,4 e heparina a $2 \%$ tendo a função de lavagem dos sistema arterial e venoso. Para a fixação foi perfundido pela aorta solução fixadora 
de Karnovsky modificada, constituída por glutaraldeído $5 \%\left(\right.$ Merk $\left.^{\circledR}\right)$ e formaldeído a $1 \%\left(\right.$ Sigma $\left.^{\circledR}\right)$ em tampão cacodilato de sódio $\left(\mathrm{EMS}^{\circledR}\right)$ a $0,125 \mathrm{M}$ e pH 7,4.

Os timos foram removidos após a perfusão da solução fixadora de Karnovsky modificada para serem mensurados em seu eixo longitudinal e transversal (em região caudal e cranial). Foram realizados cortes seccionados transversalmente, produzindo fatias com distância média de $3 \mathrm{~mm}$ e foram imersas no fixador, e foi mensurada a estimativa do volume pelo método de Cavalieri.

O próximo passo foi lavar os fragmentos tímicos em solução cacodilato de sódio $\left(\mathrm{EMS}^{\circledR}\right)$ a $0,125 \mathrm{M}$ e pH 7,4 e imersos em uma solução de tetróxido de ósmio $\left(\mathrm{EMS}^{\circledR}\right)$ a $2 \%$.

Logo após, as amostras foram embebidas em uma solução de óxido de propileno $\left(\mathrm{EMS}^{\circledR}\right)$ e resina araldite pura (502 Polyscience $\operatorname{Inc}^{\circledR}$ ), em constante agitação e em diferentes proporções. Após estas etapas, os fragmentos foram transferidos para resina araldite pura (502 Polyscience $\operatorname{Inc}^{\circledR}$ ) e levados à estufa $\left(60^{\circ} \mathrm{C}\right)$, permanecendo durante um período mínimo de 48 horas.

Todos os blocos provenientes do material processado foram trimados para evidenciar as regiões de interesse e seccionados seriadamente com um micrômetro $(1 \mu \mathrm{m})$ de espessura utilizando navalha de vidro, com o auxílio do ultra-micrótomo $M T-X L^{\circledR}$. As secções foram coletadas sobre lâminas e secas em placa térmica $\left(\right.$ Leica $\left.^{\circledR}\right)$, e em seguida coradas com uma solução de azul de toluidina alcoólica. Posteriormente foram cobertas com uma gota de araldite (502 Polyscience $I n c^{\circledR}$ ) e montadas sob lamínula.

\subsection{VOLUME DO ÓRGÃO OU VOLUME REFERÊNCIA ( $\left.\mathbf{V}_{(\mathrm{REF})}\right)$}

Segundo o matemático Bonaventura Cavalieri (1635 apud HOWARD; REED, 1998), o volume de qualquer objeto pode ser estimado através de uma exaustiva série de secções paralelas separadas por uma distância conhecida. A estimativa se dá pela distância entre as secções ( $d$ ou $k$, sendo $d$ a nomenclatura utilizada para cortes macroscópicos e $k$ para cortes microscópicos) multiplicado pela somatória das áreas $\left(\sum \mathrm{a}\right)$ de cada secção (Equação 1) 


\section{Equação $1 \quad \mathrm{~V}_{(\mathrm{ref})}=\mathrm{d}\left(\right.$ ou k) $\times \sum \mathrm{a}$}

Após a retirada dos animais, os timos foram seccionados transversalmente, com o auxílio de uma lâmina cortante, por meio de planos macroscópicos paralelos e seriados, como descrito no trabalho de Henery e Mayhew (1989); Mayhew e Olsen (1991); Mayhew, Mwamengele e Dantzer (1990); Mayhew (1992) e Wulfsohn et al. (2004). Cada timo originou em média 4 faixas que constitui uma estimativa eficiente para o cálculo do volume tímico pelo método de Cavalieri (GUNDERSON; JENSEN, 1987; HENERY; MAYHEW, 1989; MAYHEW; OLSEN, 1991; MAYHEW, 1992). A distância entre as fatias ( $d$ ) não são precisas, então, como proposto por Gunderson et al. (1988) e Mayhew e Olsen (1991), uma distância média ( $d$ ) entre as fatias foi estimada através da mensuração do comprimento total do timo, com o auxílio de um paquímetro digital (Starrett ${ }^{\circledR}$ ), A distância média utilizada na maioria dos timos foi de $2,0 \mathrm{~mm}$.

A área das fatias de apenas uma das faces foi calculada, isto é, apenas na face caudal de cada fatia, com o auxílio de um sistema teste, logo, o volume referência dos timos foi obtido através da análise macroscópica.

A acurácia dos resultados obtidos pelo método de Cavalieri foi verificada pelo coeficiente de erro (Equação 2). Este foi calculado pela equação proposta inicialmente por Gundersen e Jensen (1987) e descrita posteriormente em outros trabalhos Pakkenberg et al. (1989); Mayhew e Olsen (1991) e Duerstock et al. (2003).

Equação 2: $\quad C E=1 / \Sigma A \times[1 / 12(3 a+c-4 b)]^{1 / 2}$

Onde :

$\sum \mathrm{A}$ - Somatória de todas as áreas das secções a

a - Somatória dos produtos de a $\times$ a

$\mathrm{b}$ - Somatória dos produtos de $\mathrm{a} \times(\mathrm{a}+1)$

c - Somatória dos produtos de a $\times(a+2)$ 


\subsection{MÉTODO ORIENTATOR}

O tecido ou órgão isotrópico é aquele onde a estrutura aparece homogeneamente, com as mesmas características em todas as direções, diferente dos cortes anisotrópicos onde há uma orientação na apresentação do material (MANDARIM, 1994).

A estimativa de muitos parâmetros estereológicos necessita de secções isotrópicas, ou seja, de cortes AUI (Aleatórios e Uniformemente Isotrópicos) ou IUR (Isotropic Uniform Random) como pré-requisito. Hoje para obtermos cortes AUI ou IUR de qualquer tecido ou órgão utilizamos o método orientator (MATTFELDT et al., 1990).

Este método é utilizado para estimar o comprimento (Lv), densidade de superfície (Sv) e outros parâmetros estereológicos em secções isotrópicas (MATTFELDT et al., 1990).

Um fragmento de tecido ou órgão deve ser seccionado em dois cortes consecutivos. O primeiro corte deve ser realizado em um ângulo determinado aleatoriamente, depois a face de corte deve ser apoiada no plano da mesa e novamente o tecido deve ser seccionado segundo um ângulo aleatório (MATTFELDT et al., 1990).

Para tornar cada fatia isotrópica, as mesmas foram orientadas de acordo com seu eixo longitudinal e submetidas a sistemas com diferentes ângulos. Cada sistema foi adaptado para o tamanho de cada fatia original e para a amostra formada. Estes sistemas são denominados relógio $\phi$ (seno) ou $\phi$-clock, e relógio $\theta$ (co-seno) ou $\theta$ clock (Figura 2). O primeiro sistema foi o $\phi$-clock, coloca-se a fatia em seu eixo longitudinal no sentido de ângulo $\mathrm{O}^{\circ}$, escolhe-se um ângulo aleatório e a fatia é seccionada. Um dos dois pedaços formados foi escolhido e colocado no $\theta$ - clock com a face do corte para baixo e novamente seccionado em um novo ângulo aleatório. Os fragmentos foram seccionados até atingirem o tamanho ideal (cerca de $1 \mathrm{~mm}^{2}$ ) e processados para microscopia de luz de cortes semi-finos. 
Figura 2 - Sistemas testes com diferentes ângulos utilizados no método orientator. A - relógio $\theta$ (co-seno) ou $\theta$ - clock. B - relógio $\phi$ (seno) ou $\phi$-clock

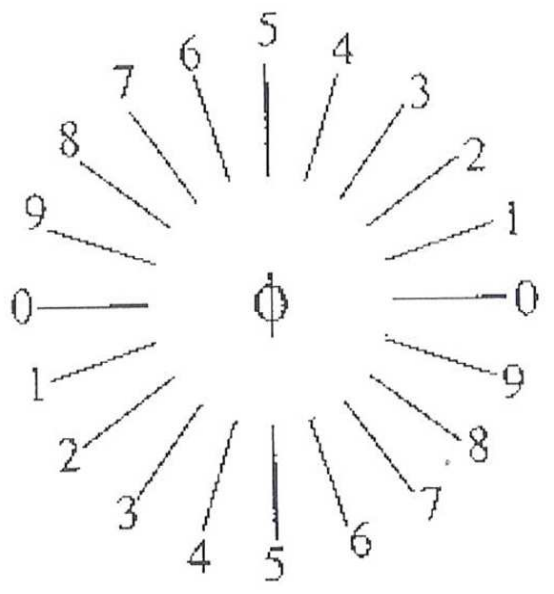

A

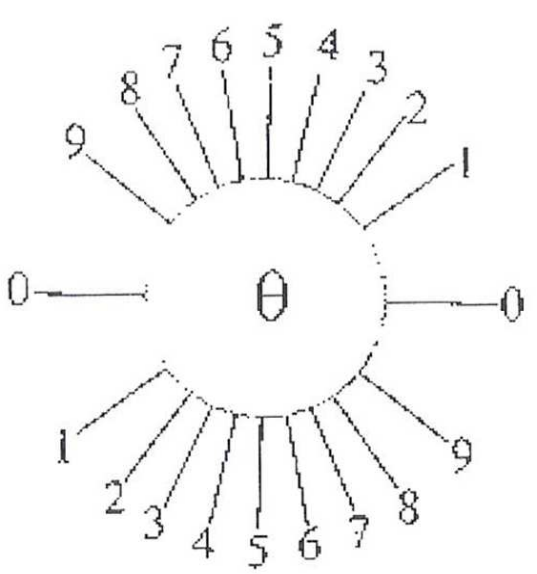

$\mathrm{B}$

Fonte: Adaptado de Mandarim-de-Lacerda (2003)

\subsection{ANÁLISE ESTEREOLÓGICA}

O objetivo da estereologia é determinar parâmetros quantitativos tridimensionais de estruturas anatômicas a partir de cortes bidimensionais, valendose da geometria e da estatística (MANDARIM, 1994).

Geometricamente os vasos são estruturas tubulares ideais para um eficiente transporte e distribuição de fluídos por todo o organismo. Formam uma rede complexa e ramificada, conectados de forma única, a reconstrução física desta rede é baseada em secções seriadas. O número de capilares na rede equivale com a conectividade, com isso, na prática estereológica o número de capilares é igual à estimação da conectividade (NYENGAARD; BENDTSEN; GUNDERSEN, 1988).

A área de superfície vascular é o produto do seu comprimento e circunferência, sendo importante para a descrição quantitativa dos vasos (NYENGAARD; BENDSTEN; GUNDERSEN, 1988). 


\subsubsection{Método Disector Físico}

A quantificação vascular no timo de gatos foi realizada utilizando o método estereológico do disector físico. Este método permite contar partículas independentemente do tamanho, forma, distribuição ou orientação, em um volume conhecido, utilizando pares de secções provenientes de cortes seriados (PAKKENBERG; GUNDERSEN, 1988; COGGESHALL, 1992; COGGESHALL; LEKAN, 1996). O disector permite a composição das estruturas em três dimensões utilizando um sistema teste com uma área (a) conhecida, número de pontos (p), e um plano paralelo com uma altura (h) (STERIO, 1984).

Cada disector é constituído por duas secções idênticas separadas por uma altura conhecida, sendo estas secções denominadas de "reference-section" e "lookup section", e as partículas encontradas na "reference-section", mas não na "look up section" são chamadas de "transects" (GAGLIARDO, 2003).

Os disectores foram aplicados por toda a extensão do timo para permitir que todas as regiões apresentem as mesmas chances de serem amostradas, obedecendo a um sistema de amostragem denominado "systematic random sampling scheme" (MAYHEW; GUNDERSEN, 1996).

De acordo com Gundersen et al. (1988) e Mayhew e Gundersen (1996) uma população de 100 a 200 perfis foram contados para estimar a densidade numérica. Assim sendo, é imperativa a necessidade de um estudo piloto para se estabelecer a quantidade de disectors utilizada para atingir este número populacional. Neste trabalho, foi determinado que em torno de 10 disectors nos timos forneciam uma contagem ideal, isto é uma quantidade mínima de 100 perfis.

A observação do material e a captura da imagem foram realizadas com 0 auxílio do microscópio Olympus ${ }^{\circledR}$ BX 60 e de uma câmera digital AxioCam HPC Zeiss $^{\circledR}$, na qual a imagem da "reference section"e da "look -up section" foi capturada e transferida para a tela de um computador. Sobre a tela foi aplicada uma área teste (com linhas de inclusão e exclusão), e os perfis vasculares presentes na "referencesection" foram comparados com os perfis da "look-up section". Os perfis identificados em cada secção mudam entre os planos seccionais em três possibilidades para estimar a conectividade. 
Sabendo da quantidade de disectors necessária e o tamanho da amostra do timo, este foi mensurado com a utilização de um paquímetro digital (Starret®), foi possível delimitar um intervalo de secções no qual permitiu que todas as regiões dos timos fossem amostradas. Desta forma, foi utilizado um $k=200$ para os timos. A primeira secção de análise do disector, em todos os grupos, foi escolhida de maneira aleatória como descrita anteriormente.

A área teste (At) utilizada foi definida por um conjunto de linhas (retas) e pontos, além de linhas de inclusão e exclusão (Figura 3), onde os perfis que tocam as linhas de exclusão não são considerados, permitindo chance igual de amostragem dos perfis, independente do tamanho destes, em uma abordagem imparcial. Este foi sobreposto à imagem morfológica para a contagem estereológica.

No disector com área $=a$, e com a distância entre as secções $=h$, o volume do disector $\left(\mathrm{v}_{(\mathrm{dis})}\right)$ é calculado de acordo com equação 3.

\section{Equação $3: v_{\text {(dis) }}=\mathrm{a} \cdot \mathrm{h}$}

Figura 3 - Em A, a "reference section" é delimitada por uma área teste com linhas de inclusão (linhas pontilhadas) e de exclusão (linhas cheias). Em B, a "look-up section" é delimitada por uma

A área teste rígida.

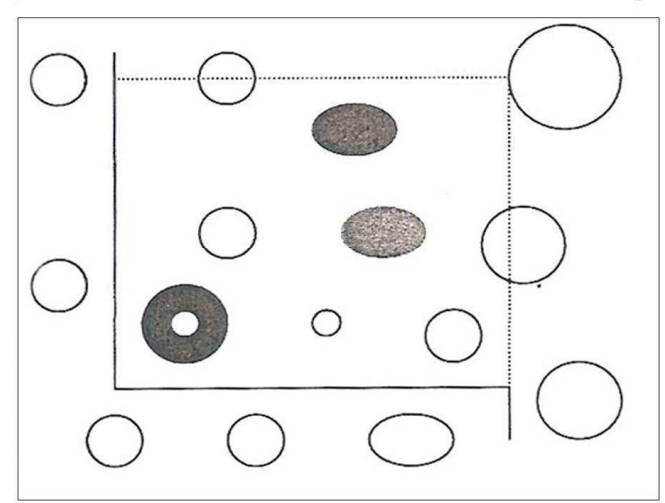

B

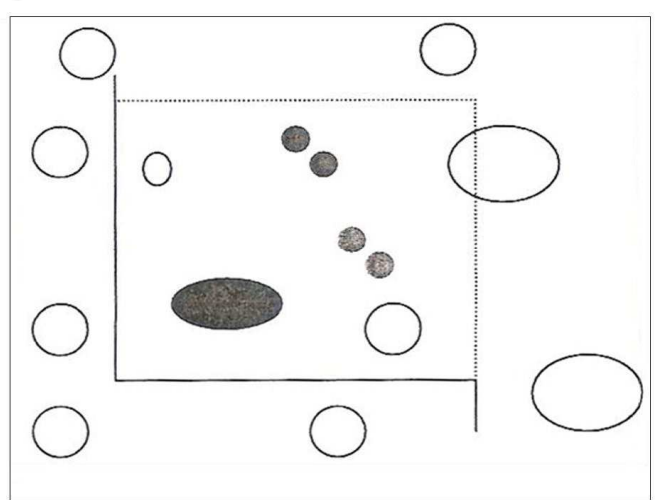




\subsubsection{Determinação do Número de Euler no Método de Disector}

O princípio de ConnEulor ou de conectividade, é uma extensão do método de disector para a estimação do número de estruturas. Cada estrutura tem um número de Euler ou conectividade que é obtido com exaustivas secções seriadas da amostra (DEHOFF et al., 1972; KROUSTRUP; GUNDERSEN, 2001).

O número de Euler é um valor inteiro, específico, que pode ser definido por algumas estruturas em alguma dimensão (DEHOFF, 1972; KROUSTRUP; GUNDERSEN, 2001;). Sua estimação é independente da direção e orientação da leitura.

O conceito de conectividade está intimamente relacionado com a integridade geométrica das curvas de superfície, esta estimação estreológica foi estudada primeiramente por F. Rhine's e R. Dehoff's na Flórida (NYENGAARD; BENDTSEN; GUNDERSEN, 1988).

De acordo com Kroustrup e Gundersen (2001) para estimar a conectividade deve-se enumerar os chamados planos tangenciais. Em cada ponto de uma superfície lisa no espaço tridimensional pode-se definir a curvatura da superfície, que é de 3 tipos:

- Superfície do lúmen do capilar convexa, sendo caracterizado por uma saliência externa, o raio da curvatura tem seus eixos na margem luminal da superfície, conferindo partes completamente fechadas chamadas de "Hole", H ou fragmentos luminais (Figura $4 \mathrm{~A})$.

- Superfície côncava, sendo o oposto da convexa, conferindo uma nova parte isolada chamada de "Island", I, da parede interna do lúmen, aparentando um lago luminal (luminal lagoon) (Figura 4B).

- Superfície em sela ou "Saddle surface" é complexa: em uma direção (desigual ao longo de todo o eixo capilar) a curvatura é côncava com o centro do raio da curvatura saindo do lúmen, na outra direção (do outro lado do capilar) a curvatura é, normalmente, do tipo convexa, é a divisão do lúmen capilar em dois ou mais lumens, uma conexão luminal ou uma nova conexão 
entre as partes isoladas chamadas também de "Bridge", B (Figura 4C).

Figura 4 - Amostragem do disector e estimação dos planos tangenciais. Em A, a superfície convexa do capilar é mostrado na "reference setion" e não na "Look-up section", estruturas chamadas de "Hole". Em B, uma irregularidade da parede do capilar é observada conferindo uma nova parte isolada chamada de "Island". Em C, na "reference section" a curvatura é côncava, e na "look-up section" a curvatura é do tipo convexa formando uma divisão do lúmen capilar em dois ou mais lumens, chamados também de "Bridge"

\section{Estrưtura}

A
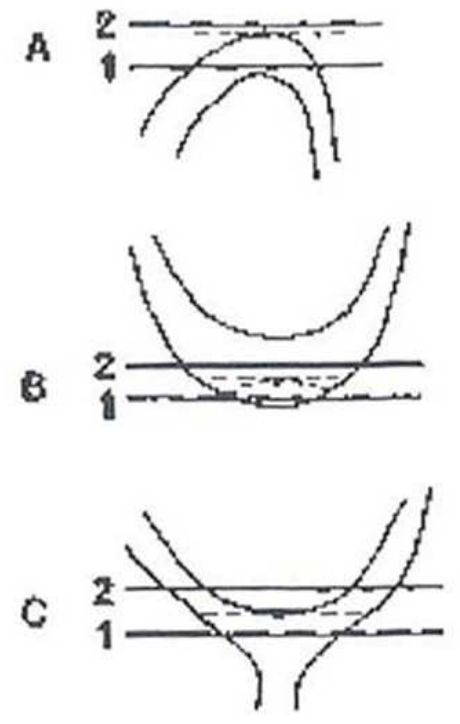

\section{1: Reference 2: Look-up}
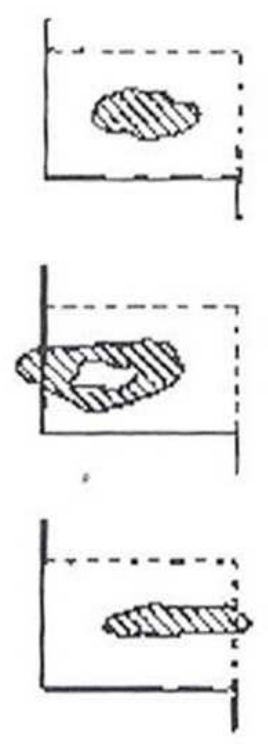

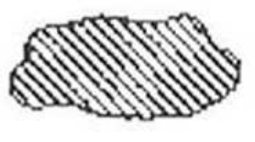

$\Delta$

Assim, segundo Kroustrup e Gundersen (2001), as "Bridges" contribuem com -1 , e as "Islands" e "Holes" contribuem com +1 , formando a equação 4.

$$
\text { Equação 4: } \quad \sum \mathrm{X}=\frac{\sum \mathrm{I}-\Sigma \mathrm{B}}{2}+\sum \mathrm{H}
$$

Onde:

$\Sigma \mathrm{X}=$ número total de Euler

$\Sigma \mathrm{I}=$ número total de "Islands"

$\Sigma \mathrm{B}=$ número total de "Bridges"

$\Sigma \mathrm{H}=$ número total de "Holes" 
A constante 2 no denominador, reflete que a contagem de "Islands", "Bridges", "Holes" no disector é representado nas duas direções simultaneamente.

Em uma amostra uniforme e randômica do disector a densidade do número de Euler $\left(X_{v}\right)$ é estimada de acordo com a equação 5.

$$
\text { Equação 5: } \quad X_{v}=\frac{\sum X}{\sum_{v} \text { (dis) }}
$$

\subsubsection{Estimação da Densidade Numérica Vascular ( $\left.\mathrm{N}_{\mathrm{v}(\mathrm{vasc})}\right)$}

Calculando a área do sistema teste (a) e o número de Euler na "reference section" com a respectiva "look-up section", obtemos a densidade numérica vascular $\left(\mathrm{N}_{\mathrm{v}(\mathrm{vasc})}\right)$, ou densidade de conectividade, pela equação 6 (NYENGAARD; MARCUSSEN, 1993)

$$
\text { Equação 6: } \quad \mathrm{N}_{\mathrm{v}(\text { vasc })}=\frac{-\sum \mathrm{X}}{2 \cdot \mathrm{h} \cdot \Sigma \mathrm{a}}
$$

Onde:

$\sum X=$ Número de Euler

$\mathrm{H}=$ Altura do disector, distância entre os 2 planos de secções

$\sum \mathrm{a}=$ Total de áreas dos disectores

\subsubsection{Número Total de Vasos no Órgão ( $\left.\mathrm{N}_{(\text {vasc })}\right)$}

Com a densidade numérica e o volume referência do órgão calculado pelo método de Cavalieri, obtemos o número total de vasos no órgão (Equação 7).

Equação $7: \quad \mathrm{N}_{(\text {vasc })}=\mathrm{N}_{\mathrm{v}(\text { vasc })} \cdot \mathrm{N}_{(\text {ref })}$ 
4.5.5 Estimação da densidade de comprimento do vaso (Lv), comprimento do vaso (L), densidade de superfície de área (Sv), superfície de área (S).

Segundo Nyengaard (1993), a densidade de comprimento do vaso (Lv) e a densidade de superfície de área (Sv) são estimadas de acordo com as equações 8 e 9.

$$
\text { Equação 8: Lv=2 . Qa }
$$

Onde :

$$
\mathrm{Qa}=\text { Perfis de vaso por área }
$$

Equação 9: $S v=2 . I_{L}$

Onde:

$\mathrm{I}_{\mathrm{L}}=$ Número de intersecções entre os vasos e as linhas do sistema teste.

Para obtermos o comprimento do vaso e a área de superfície, multiplica-se a densidade de comprimento (Lv) e a densidade de superfície (Sv) pelo volume de referência do órgão $\left(V_{(\text {ref })}\right)$, equações 10 e 11.

$$
\text { Equação 10: } L=L v \cdot V_{(\text {ref })} \quad \text { Equação 11: } S=S v \cdot V_{(\text {ref })}
$$

\subsection{ANÁLISE ESTATÍSTICA}

A análise estatística dos resultados foi realizada pelo programa BioEstat 3.0 (AYRES et al., 2003).

As variáveis correlacionadas são: comprimento, largura, espessura do timo, L, $L v, S, S v, N_{v(\text { vasc })}, N_{(\text {vasc })}$ e $V_{\text {(ref). }}$ 


\subsection{PREPARAÇÃO DO MATERIAL PARA PCR EM TEMPO REAL}

Para realização deste método foram utilizados 6 grupos $(35,45,55,65$ dias de gestação e 6 meses e 1 ano de idade) de gatos domésticos.

As amostras tímicas foram acondicionadas em tubos eppendorf de $1,5 \mathrm{ml}$ RNase free, para então serem imediatamente armazenadas em nitrogênio líquido e mantidas em um freezer à $-80 \stackrel{\circ}{\circ}$ até o procedimento para a extração de seu RNA.

\subsubsection{Extração de RNA Total}

Para a extração do RNA as amostras foram acondicionadas em gelo e acrescidas de $1,0 \mathrm{~mL}(1000 \mu \mathrm{l})$ de Trizol $^{\circledR}$ e, com o auxílio do aparelho homogenizador de tecidos, POLITRON ${ }^{\circledR}$, foram homogeneizadas. O aparelho homogenizador foi lavado com água tratada com Dietil Pirocarbonato (DEPC), água RNase-ZAP (removedor de RNase) e novamente com água DEPC após cada amostra. $O$ homogenato foi armazenado a temperatura ambiente durante 5 minutos. Após esse período, $200 \mu \mathrm{l}$ de clorofórmio foram adicionados, seguido de vigorosa agitação com as mãos por 15 segundos. Os tubos ficaram em incubação por 3 minutos a temperatura ambiente. Posteriormente foram centrifugados a $11500 \mathrm{rpm}$ a $4^{\circ} \mathrm{C}$ por 15 minutos. Após a centrifugação foi removida a fase aquosa para tubos limpos e descartado o sedimento. Foram adicionados $500 \mu \mathrm{l}$ de isopropanol e homogeneizado com as mãos, seguido de incubação por 10 minutos a temperatura ambiente. Novamente centrifugados a $11500 \mathrm{rpm}$ a $4^{\circ} \mathrm{C}$ por 10 minutos. Foi descartado o sobrenadante e os tubos foram colocados sob fluxo laminar estéril para secagem completa. O RNA forma um pellet no fundo do tubo. Após secagem foram lavados com $1 \mathrm{~mL}$ de etanol 75\% (feito com água miliQ autoclavada). Centrifugadas a $9000 \mathrm{rpm}$ a $4^{\circ} \mathrm{C}$ por 5 minutos. Seguido de secagem do pellet durante 15 minutos a temperatura ambiente e solubilizado com $20 \mu \mathrm{l}$ de água tratada com dietil pirocarbonato (DEPC). 


\subsubsection{Quantificação do RNA Total}

A quantificação foi realizada em aparelho biofotômetro (BioPhotometer plus da Eppendorf) que utiliza a espectrofotometria para detectar a concentração de RNA.

Uma alíquota de $1 \mu \mathrm{l}$ do RNA Total, que foi solubilizado no procedimento acima, foi diluída em $49 \mu \mathrm{l}$ de água DEPC, em uma proporção de 1:50. Primeiramente foi feita a calibração do aparelho com água DEPC, para posterior quantificação dos RNAs.

As diluições de cada amostra foram colocadas em cubetas Eppendorf UVette ${ }^{\circledR}$ e uma de cada vez inseridas no aparelho. Os ácidos nucléicos possuem um pico de absorção em $260 \mathrm{~nm}$ e outro em $280 \mathrm{~nm}$ por isso a leitura foi feita nesta razão de $260 / 280 \mathrm{~nm}$ e os valores que foram considerados estavam próximos de 1,80.

\subsubsection{Transcrição Reversa}

Para assegurar que os resultados foram oriundos do mRNA e não do DNA genômico, as amostras foram tratadas com DNAse antes de serem submetidas ao RT-PCR. O volume da concentração de RNA total a ser tratado é calculado para que contenha $1 \mu \mathrm{g}$ de RNA Total por $\mu \mathrm{l}$. A este volume é adicionado $1 \mu \mathrm{l}$ de Tampão 10x DNAse I, $1 \mu \mathrm{l}$ de DNAse e água miliQ autoclavada (Invitrogen Carlsbad, CA - USA) (completando um volume final de $9 \mu \mathrm{l}$ ), por 15 minutos no gelo. Em seguida foi adicionado $1 \mu \mathrm{l}$ de EDTA (ácido etilenodiamino tetracético) por tubo, o qual inibe a atividade da desoxirribonuclease (DNAse) incubados por 10 minutos a $60^{\circ} \mathrm{C}$ no Termociclador Mastercycler $^{\circledR}$ Family Eppendorf $^{\circledR}$.

Nesta etapa, o RNA mensageiro foi copiado para cDNA por uma enzima transcriptase reversa. Foram adicionados $1 \mu$ do Oligo DT (Eppendorf) e $1 \mu \mathrm{l}$ de dNTPs (Eppendorf) em cada tubo eppendorf e incubados por 5 minutos a $65^{\circ} \mathrm{C}$ no termociclador.

Em seguida, foi adicionado $4 \mu \mathrm{l}$ de 5x Buffer, $1 \mu \mathrm{l}$ DTT, $1 \mu \mathrm{l}$ RNAseOUT, $1 \mu \mathrm{l}$ de Superscript III, $1 \mu$ l de água miliQ autoclavada em cada tubo e incubados por 50 
minutos a $37^{\circ} \mathrm{C}$ e depois 15 minutos a $70^{\circ} \mathrm{C}$ no termociclador. Finalizando uma última incubação a $4^{\circ} \mathrm{C}$ por 2 minutos. Com o término da transcrição o cDNA foi armazenado a $-20^{\circ} \mathrm{C}$ até o momento do PCR em tempo real. Os reagentes utilizados eram provenientes da Invitrogen Carlsbad - USA.

\subsubsection{PCR em Tempo Real}

Após a transcrição reversa (RT), foi realizado o PCR em Tempo Real (Real Time PCR) no aparelho ABIPrism ${ }^{\circledR} 7500$ e as fases de anelamento, extensão e desnaturação ocorrem durante ciclos dentro do termociclador e este está acoplado a uma câmera. A quantificação relativa da amplificação é feita pela fluorescência captada pela unidade óptica do aparelho. A amplificação é detectada onde as condições "ótimas" para o PCR são mantidas, ou seja, na fase exponencial.

O sistema adotado para a detecção da expressão gênica do fator de crescimento VEGF e de seus receptores Flt-1 e KDR foi o sistema TaqMan, onde a sonda é conjugada com um fluoróforo

Foi preparado o mix que é constituído de 6,25 $\mu \mathrm{l}$ de Tampão Universal PCR Master Mix (Applied Biosystems, Foster, USA), $0.5 \mu$ do primer sense e anti-sense, $3,25 \mu \mathrm{l}$ de água miliQ autoclavada e 2,5 $\mu \mathrm{l}$ de cDNA da amostra completando um volume final de $12,5 \mu \mathrm{l}$. Todas as amostras foram testadas em duplicata com todos os primers.

As sequências específicas utilizadas para a confecção dos primers para VEGF, Flt-1 e KDR foram aquelas depositadas no banco público do GenBank - NCBI (http://www.ncbi.nlm.nih.gov) (Quadro 1).

Os primers foram confeccionados a partir da sequência de cão, uma vez que não há depositado no Genbank as sequências referente aos receptores Flt-1 e KDR para o gato. Como a similaridade do cão e do gato foi $100 \%$ de compatibilidade optamos por usar a do cão. 
Quadro 1 - Sequência dos oligonucleotídeos iniciadores utilizados para a amplificação do, VEGF, KDR, Flt-1, GAPDH, $\mathbf{S}=$ sense, $\mathbf{A}=$ anti-sense, $\mathbf{P}=$ probe.

\begin{tabular}{|l|l|l|}
\hline Gene alvo & $\begin{array}{l}\text { Número da sequência no } \\
\text { GenBank }\end{array}$ & Primers \\
\hline VEGF-A & Nm_001003175 & $\begin{array}{l}\text { S GCCCACTGAGGAGTTCAACAT } \\
\text { A GCTGGCCTTGATGAGGTTTGAT } \\
\text { P CACCATGCAGATTATG }\end{array}$ \\
\hline KDR & DQ269018 & $\begin{array}{l}\text { S GGCCTTGACTTCAACTGGGAATACC } \\
\text { A GGTTTTTAGGTCCCGGTTAACAAGT } \\
\end{array}$ \\
\hline FIt-1 & AF262963 & S GGCCAGACACTGTATCTCAAATGTA \\
& & A TCCTTTCTCACTGTTTCAGGCAAA \\
& & P AAGCAGCCCATTCATG \\
\hline GAPDH & AB038240 & S ACGGGAAGTCCATCTCCATCTT \\
& & A CACCAGCATCACCCCATTTG \\
& & P ATGTTGGCAGGATCTC \\
\hline
\end{tabular}

No método comparativo para a expressão relativa de um gene alvo em comparação a um gene de referência, baseado na eficiência dos primers (PFAFFL, 2001), a quantidade do gene alvo é normalizada a um controle endógeno e calculada em relação a um calibrador.

Fórmula:

$$
\text { (E target) }{ }^{\wedge} \mathrm{CP} \text { target (control-sample) }
$$

ratio $=$

(E ref) ${ }^{\wedge} \mathrm{CP}$ ref (control-sample)

Onde:

$E$ target $=$ Eficiência do gene alvo

E ref $=$ Eficiência do gene constitutivo

${ }^{\wedge} \mathrm{CP}$ target $=\mathrm{Ct}$ do controle menos a amostra do gene alvo transcrito

${ }^{\wedge} \mathrm{CP}$ ref $=\mathrm{Ct}$ do controle menos a amostra do gene construtivo transcrito

A eficiência dos primers foi testada para determinar se os pares de primers apresentam eficiência próxima de $100 \%$, ou seja, se duplicam o produto de PCR a cada ciclo de reação. Para tal, foram utilizadas diluições de cDNA de 1/2, 1/4, 1/8, 1/16 e 1/32, o que gera uma curva de amplificação da amostra em função de sua 
concentração. Para se calcular a eficiência utiliza-se a inclinação da reta diretamente na fórmula abaixo:

$E=10^{(-1 / \text {-slope })-1} \times 100$

Os valores obtidos para a expressão gênica relativa do sistema VEGF no timo dos fetos de gatos foram submetidos à análise estatística utilizando-se o programa SAS e os testes ANOVA quando comparadas às expressões relativas às diferentes idades gestacionais dos fetos e de vida nos adultos.

\subsection{PROCESSAMENTO DO MATERIAL PARA IMUNO-HISTOQUÍMICA}

\subsubsection{Fixação dos tecidos}

As amostras coletadas foram fixadas em formol tamponado a $4 \%$ por 24 horas. Após exaustivas lavagens em PBS para retirada do fixador, as amostras foram desidratadas em uma série de etanol com concentrações crescente, etanol 70ํe e etanol 90ำ por 1 hora cada, em seguida três séries de 1 hora cada de álcool absoluto. Sendo então diafanizadas em Xilol com três séries de 1 hora cada. Após a diafanização iniciou-se a inclusão em paraplast (Histosec ${ }^{\circledR}$ - Merk - Alemanha) sob protocolo padrão. Com os blocos de paraplast endurecidos foi realizado cortes de 5 $\mu \mathrm{m}$ de espessura em micrótomo automático Leica.

\subsubsection{Tratamento das lâminas com 3-aminopropyltrietroxy-silano (APES)}

Os cortes de $5 \mu \mathrm{m}$ foram colocados sobre lâminas previamente tratadas através de banhos em acetona $96 \%$ e solução de $5 \%$ de 3 -aminopropyltrietroxysilano (APES - Sigma-Aldrich Co., USA) diluída em acetona, seguindo-se de dois banhos rápidos em acetona e um em água destilada. As lâminas com os cortes de $5 \mu \mathrm{m}$ foram colocadas em estufa a $37^{\circ} \mathrm{C}$ por 24 horas, para que, assim como a 
lâmina, o corte seque e se fixe a esta, evitando o descolamento do corte da lâmina durante o processo de imuno-histoquímica.

\subsubsection{Imuno-histoquímica do vegf e seus receptores (FIt-1 e KDR)}

As lâminas foram desparafinizadas em 2 séries de Xilol por 10 minutos cada, seguidas de reidratação decrescente de etanol, permanecendo 2 séries de 5 minutos cada em etanol absoluto. Após, foi realizado o bloqueio da peroxidase endógena, com uma solução a $3 \%$ de peróxido de hidrogênio PA e metanol previamente resfriado, por 30 minutos a $20^{\circ} \mathrm{C}$. Em seguida, as lâminas passaram por mais uma série de etanol absoluto por 5 minutos, etanol $90^{\circ}$ por 5 minutos, etanol $70^{\circ}$ por 5 minutos e água destilada por 5 minutos. Foram imersas em tampão citrato e aquecidas a $96^{\circ}$ durante 30 minutos e resfriadas 20 minutos em temperatura ambiente. Após foram lavadas em 3 séries de 5 minutos em solução salina tamponada com fosfato (PBS). Outro bloqueio de reações inespecíficas foi feito utilizando o Protein Block (Dako, Glostrup, Danmark) por 20 minutos em câmara úmida em temperatura ambiente.

Os anticorpos primários, descritos no Quadro 2 abaixo, foram colocados sobre os cortes e, os cortes controles receberam PBS, a incubação durou 20 horas em câmara úmida a $4^{\circ} \mathrm{C}$. 
Quadro 2 - Anticorpos primários utilizados na reação de imuno-histoquímica

\begin{tabular}{|c|c|c|c|c|}
\hline Anticorpo & Tipo & Hospedeiro & № de catálogo & Diluição \\
\hline VEGF & Policlonal & Coelho & $\begin{array}{l}\text { VEGF (A20): sc-152, } \\
\text { Santa Cruz } \\
\text { Biotechnology® Inc., } \\
\text { Santa Cruz, CA, USA }\end{array}$ & $1: 500$ \\
\hline Flt-1 & Policlonal & Coelho & $\begin{array}{l}\text { Flt-1 (C17): sc- } \\
\text { 316, Santa Cruz } \\
\text { Biotechnology® Inc., } \\
\text { Santa Cruz, CA, USA }\end{array}$ & $1: 500$ \\
\hline KDR & Policlonal & Coelho & $\begin{array}{l}\text { Flk-1 (C20): sc- } \\
\text { 315, Santa Cruz } \\
\text { Biotechnology® Inc., } \\
\text { Santa Cruz, CA, USA }\end{array}$ & $1: 500$ \\
\hline
\end{tabular}

Após 20 horas, os cortes foram lavados em PBS por 3 séries de 5 minutos cada, e em seguida foi realizado a incubação do anticorpo secundário universal (Kit Streptavidina-Biotina, LSAB+System-HRP, Dako, Glostrup, Danmark) por 45 minutos em câmara úmida, temperatura ambiente. As laminas foram lavadas em PBS, 3 séries de 5 minutos cada e incubadas em solução amplificadora de estreptavidina por 45 minutos em câmara úmida, temperatura ambiente, em seguidas lavadas novamente em PBS. A revelação da reação de imuno-histoquímica foi realizada com a solução de diaminobenzidina (Kit DAB Chromogen + Substrate Buffer, LSAB+System-HRP, Dako, Glostrup, Danmark), lavadas em 2 séries de 10 minutos em água destilada, contracoradas em hematoxilina diluída 1:1, em seguida lavagem

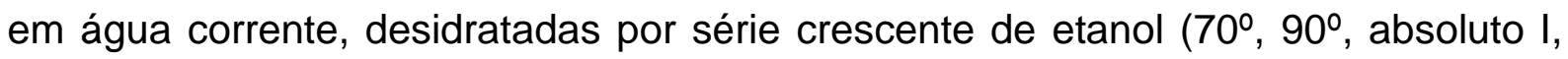
absoluto II) por 5 minutos cada, diafanizadas em Xilol (2 séries de 5 minutos cada).

A montagem das lamínulas sobre as lâminas foi feita com resina sintética dissolvida em tolueno (Permount ${ }^{\mathrm{TM} 1}$ ). 
Para controle negativo utilizou-se incubação de PBS em substituição ao anticorpo primário em um dos cortes sobre a lâmina. Para controle positivo foi utilizado tecido placentário de bovino e cão com comprovada marcação para os anticorpos utilizados.

Os cortes de tecidos tímicos foram observados em microscópio de captura de imagem Zeiss ${ }^{\circledR}$, obtidas através do programa Image-Pro ${ }^{\circledR}$ Plus $^{4}$.

\subsection{PROCESSAMENTO PARA MICROSCOPIA ELETRÔNICA DE VARREDURA}

Para esta técnica os timos foram fixados em solução de Karnovski. Posteriormente foram lavados 3 vezes em tampão fosfato a 0,1 M pH 7,4 durante 15 minutos e pós fixados em tetróxido de ósmio a $1 \%$ por 1 hora e meia. Em seguida foram novamente lavados por 3 vezes com tampão fosfato a 0,1 M pH 7,4 com duração de 15 minutos e 2 lavagens em água destilada por 15 minutos cada. Após as lavagens, foram tratados com ácido tânico 1\% durante 1 hora. Em seguida 2 lavagens de 10 minutos em água destilada. Posteriormente foram realizadas seguidas desidratrações em série gradual de etanol, 50\%, 70\% e 90\% por 10 minutos cada, e 4 desidratações em álcool absoluto por 10 minutos.

Por fim secagem do material em ponto crítico (Balzers CPD 020), montagem do material em suportes metálicos e recobrimento metálico em ouro ("sputtering" Emitech K550). Para observar tais resultados foi utilizado o microscópio eletrônico ME Leo 435 VP. 
RESULTADOS 


\section{RESULTADOS}

Os resultados estão divididos em tópicos, de acordo com a metodologia empregada neste trabalho.

\subsection{ESTEREOLOGIA}

Os resultados estereológicos dos animais de 35, 45 e 55 dias de gestação foram analisados anteriormente (BARROSO, 2007). Estes dados complementam e servem de base para análises dos animais de 65 dias de gestação, filhotes de 6 meses e adultos de 1 ano.

Os aspectos macroscópicos como o comprimento, a espessura, a largura e o volume, e os aspectos microscópicos como densidade de comprimento do vaso (Lv), comprimento do vaso (L), densidade de superfície de área (Sv), superfície de área (S), densidade numérica vascular $\left(\mathrm{N}_{\mathrm{v}(\text { vasc })}\right)$, número total de vasos $\left(\mathbf{N}_{\text {(vasc) }}\right)$ do timo apresentaram gradativo conforme o aumento da faixa de desenvolvimento dos fetos até filhotes de 6 meses de idade. Observamos uma diminuição nos adultos de 1 ano de idade. Os valores e os gráficos das variáveis são encontrados nas tabelas 1 e 2 e no Gráfico 1.

Com as análises estatísticas do teste de Wilcoxon, comparando os grupos, pôde-se observar que não houve diferença estatística significante $(p<0,05)$ nas variáveis macroscópicas de volume, largura, espessura e comprimento.

Com as análises estatísticas do teste de Mann-Whitney, comparando os sexos, observamos que não houve diferença estatística significante $(p<0,05)$ nas variáveis macroscópicas de volume, comprimento, largura e espessura. Já as variáveis microscópicas não foram estatisticamente significante na densidade de comprimento do vaso - Lv, comprimento do vaso (L), superfície de área (S), estimação da densidade numérica vascular $\left(\mathrm{N}_{\mathrm{v}(\mathrm{vasc})}\right)$, número total de vasos no órgão $\left(\mathrm{N}_{(\mathrm{vasc})}\right)$.

Com os resultados obtidos observamos que nos fetos de 45, 55, 65 dias de gestação e filhotes de 6 meses o comprimento do timo nas fêmeas se apresentou 
com valores de comprimento e densidade numérica vascular ( $\left.\mathrm{N}_{\mathrm{v}(\mathrm{vasc})}\right)$ maiores que nos machos. Nos fetos de 45 dias de gestação, dentre todos os parâmetros estereológicos, os machos só apresentaram valor superior ao das fêmeas no número total de vasos no órgão $\left(\mathrm{N}_{(\text {vasc })}\right)$.

Os parâmetros estereológicos estudados evidenciaram um aumento gradativo de acordo com o desenvolvimento dos animais juntamente com o desenvolvimento tímico. Pode-se identificar uma diminuição dos valores nas idades pós-natais (6 meses e 1 ano) indicando um processo de senescência tímica.

Tabela 1 - Valores das variáveis, volume referência $\left(\mathrm{V}_{(\text {ref })}\right)$, comprimento, espessura e largura do timo em machos e fêmeas nos diferentes grupos etários - São Paulo - 2007, 2011

\begin{tabular}{|c|c|c|c|c|c|}
\hline & & Volume $\left(\mathrm{cm}^{3}\right)$ & $\begin{array}{l}\text { Comprimento } \\
(\mathrm{cm})\end{array}$ & Espessura (cm) & Largura $(\mathrm{cm})$ \\
\hline \multirow[t]{3}{*}{ Fetos 35 dias } & Machos & 0,075 & 1,35 & 0,25 & 0,25 \\
\hline & Fêmeas & 0,08 & 1,05 & 0,25 & 0,25 \\
\hline & Média do grupo & 0,437 & 1,2 & 0,25 & 0,25 \\
\hline \multirow[t]{3}{*}{ Fetos 45 dias } & Machos & 0,235 & 2,1 & 0,25 & 0,4 \\
\hline & Fêmeas & 0,195 & 2,7 & 0,325 & 0,35 \\
\hline & Média do grupo & 0,215 & 2,4 & 0,287 & 0,375 \\
\hline \multirow[t]{3}{*}{ Fetos 55 dias } & Machos & 0,245 & 2,8 & 0,375 & 0,55 \\
\hline & Fêmeas & 0,26 & 3,3 & 0,35 & 0,48 \\
\hline & Média do grupo & 0,252 & 3,05 & 0,362 & 0,51 \\
\hline \multirow[t]{3}{*}{ Fetos 65 dias } & Machos & 0,36 & 3,8 & 0,48 & 0,65 \\
\hline & Fêmeas & 0,32 & 4,2 & 0,45 & 0,52 \\
\hline & Média do grupo & 0,34 & 4,0 & 0,465 & 0,585 \\
\hline Filhotes & Machos & 1,538 & 5,2 & 0,56 & 1,5 \\
\hline \multirow[t]{2}{*}{6 meses } & Fêmeas & 1,45 & 6,1 & 0,55 & 1,3 \\
\hline & Média do grupo & 1,49 & 5,65 & 0,55 & 1,4 \\
\hline Adultos & Machos & 0,92 & 4,8 & 0,52 & 1,34 \\
\hline \multirow[t]{2}{*}{1 ano } & Fêmeas & 0,67 & 5,7 & 0,48 & 1,25 \\
\hline & Média do grupo & 0,79 & 5,25 & 0,5 & 1,29 \\
\hline
\end{tabular}


Tabela 2 - Valores das variáveis densidade de comprimento do vaso (Lv), comprimento do vaso (L), densidade de superfície de área (Sv), superfície de área (S), estimação da densidade numérica vascular $\left(\mathrm{N}_{\mathrm{v}(\text { vasc })}\right)$, número total de vasos no órgão $\left(\mathrm{N}_{\text {(vasc) }}\right)$, do timo em machos $\mathrm{e}$ fêmeas nos diferentes grupos etários - São Paulo - 2007; 2011

\begin{tabular}{|c|c|c|c|c|c|c|c|c|}
\hline & & & LV & $\mathrm{L}(\mathrm{mm})$ & Sv & $\mathrm{S}\left(\mathrm{mm}^{2}\right)$ & $\mathrm{Nv}_{\text {(vasc) }}$ & $\mathrm{N}_{\text {(vasc) }}$ \\
\hline Fetos & Machos & & 306 & 30,6 & 240 & 24 & 73,8 & 73,8 \\
\hline dias & Fêmeas & & 284 & 21,84 & 241 & 18,1 & 95,7 & 70,70 \\
\hline & $\begin{array}{l}\text { Média } \\
\text { grupo }\end{array}$ & do & 295 & 26,22 & 240,5 & 21,05 & 84,75 & 72,25 \\
\hline Fetos & Machos & & 120 & 23,26 & 88 & 25 & 26,14 & 91,69 \\
\hline dias & Fêmeas & & 231 & 47,34 & 176 & 36,12 & 72,80 & 60,845 \\
\hline & $\begin{array}{l}\text { Média } \\
\text { grupo }\end{array}$ & do & 175,5 & 35,30 & 132 & 30,56 & 49,47 & 76,26 \\
\hline Fetos & Machos & & 409 & 100,3 & 386 & 128,39 & 22,02 & 268,07 \\
\hline dias & Fêmeas & & 366 & 94,32 & 204 & 52,88 & 54,7 & 144,69 \\
\hline & $\begin{array}{l}\text { Média } \\
\text { grupo }\end{array}$ & do & 387,5 & 97,31 & 295 & 90,63 & 38,36 & 206,38 \\
\hline Fetos & Machos & & 530 & 178 & 370 & 170 & 32,01 & 324,02 \\
\hline dias & Fêmeas & & 458 & 138 & 230 & 88,50 & 65,04 & 213,09 \\
\hline & $\begin{array}{l}\text { Média } \\
\text { grupo }\end{array}$ & do & 494 & 158 & 300 & 129,25 & 48,52 & 268,55 \\
\hline Filhotes 6 & Machos & & 580 & 246 & 350 & 187 & 75,34 & 216,78 \\
\hline meses & Fêmeas & & 530 & 190 & 310 & 112 & 87,92 & 198,56 \\
\hline & $\begin{array}{l}\text { Média } \\
\text { grupo }\end{array}$ & do & 555 & 218 & 330 & 149,5 & 81,63 & 207,67 \\
\hline Adulto 1 ano & Machos & & 550 & 270 & 420 & 80 & 57,06 & 210 \\
\hline & Fêmeas & & 520 & 170 & 250 & 104 & 68,23 & 160 \\
\hline & $\begin{array}{l}\text { Média } \\
\text { grupo }\end{array}$ & do & 535 & 220 & 335 & 92 & 62,64 & 185 \\
\hline
\end{tabular}


Gráfico 1- Parâmetros macroscópicos (espessura, comprimento e largura) e microscópicos, variáveis estereológicas, no timo de gatos em diferentes faixas etárias, machos e fêmeas. Variáveis: volume; comprimento do vaso (L); densidade do comprimento do vaso $\left(L_{v}\right)$; densidade de superfície de área $\left(\mathrm{S}_{\mathrm{v}}\right)$; superfície de área $(\mathrm{S})$; densidade numérica vascular $\left(\mathrm{N}_{\mathrm{v}}\right)$; número total de vasos no órgão $(\mathrm{N})$. $\mathbf{A}-$ Volume $\left(\mathrm{cm}^{3}\right)$. B - Espessura $(\mathrm{cm})$. C Comprimento (cm). D - Largura (cm). E - L(mm). F - $L_{v} \cdot \mathbf{G}-S_{v} \cdot \mathbf{H}-\mathbf{S}\left(\mathrm{mm}^{2}\right)$. I - $\mathrm{N}_{(\mathrm{vasc})}$. $\mathbf{J}-$ $\mathrm{N}_{\mathrm{v}(\mathrm{vasc})}$.
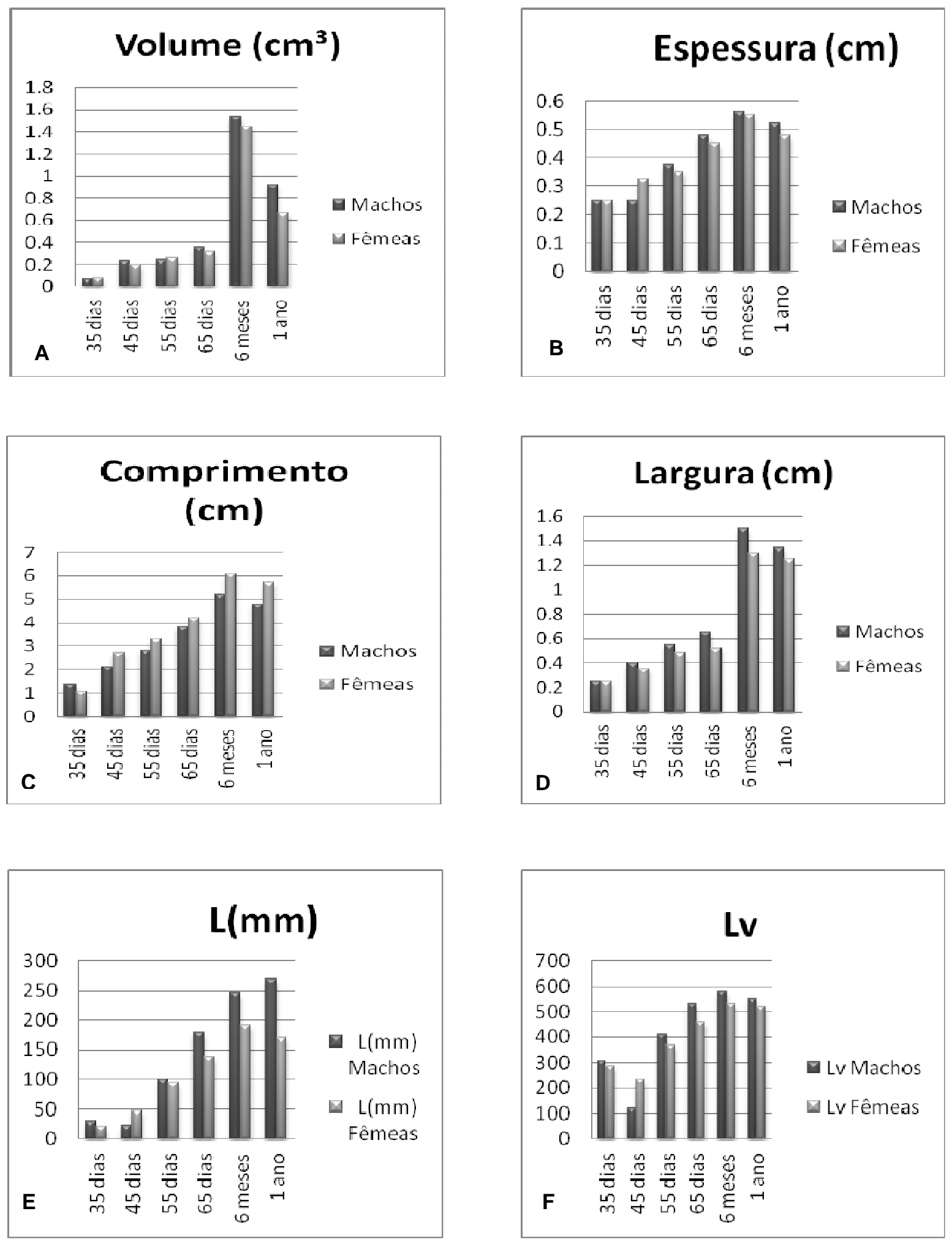

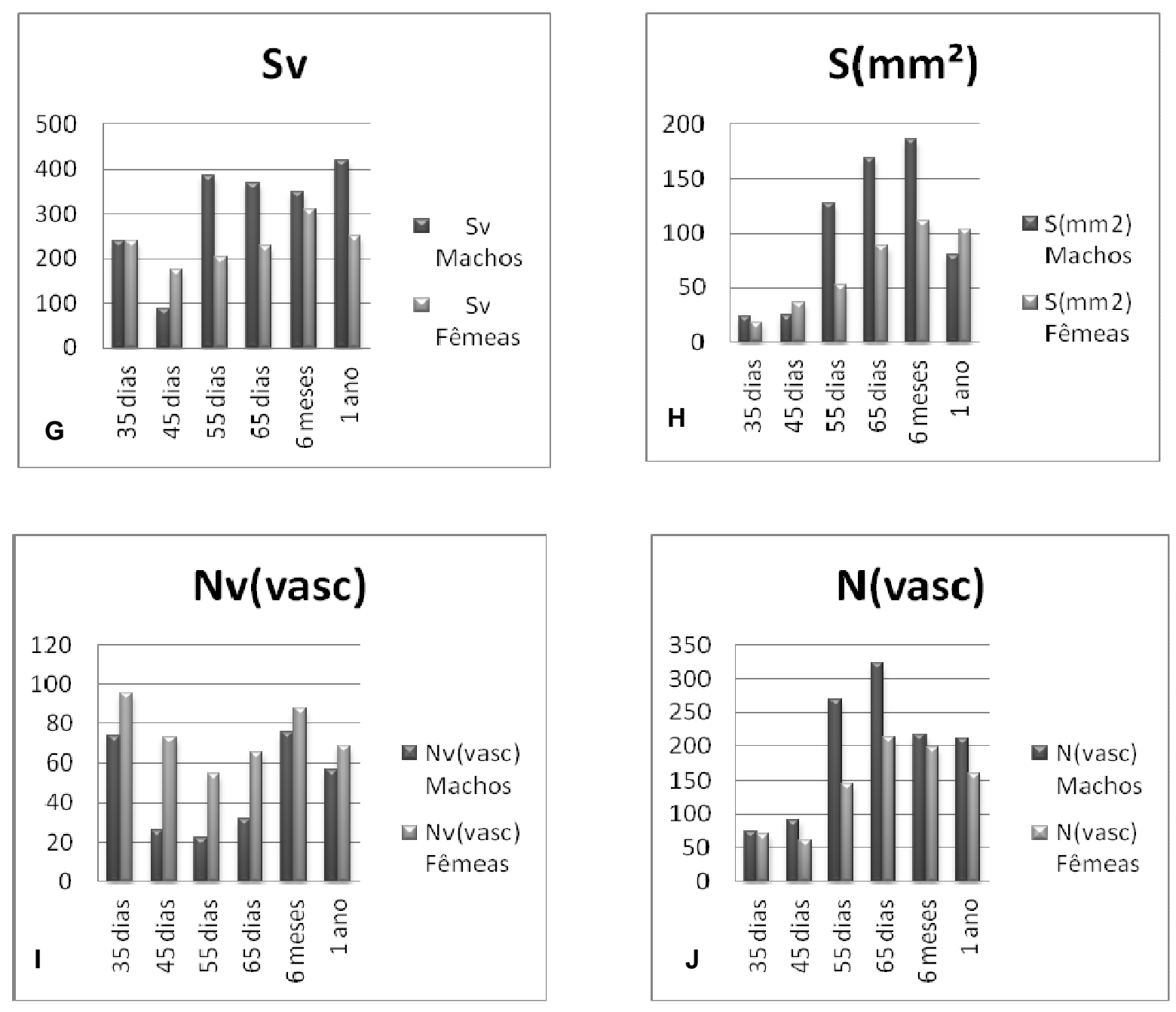

Fonte: São Paulo, 2007, 2011 
5.2 EXPRESSÃO RELATIVA DO mRNA DO VEGF E SEUS RECEPTORES (FIt-1 E KDR) PELO MÉTODO PCR - Real Time

As análises da expressão relativa do VEGF-A e seus receptores em timo de gatos foram correlacionados com o controle endógeno GAPDH ao longo do desenvolvimento, maturação do órgão e senescência, apresentando diferenças significativas $(p<0,05)$.

A expressão do mRNA do VEGF-A apresentou uma variação pequena ao longo do desenvolvimento e aos 6 meses pós-natal, e com 1 ano de idade demonstrou uma elevação significante na expressão $(p<0,05)$ (Gráfico 2 - $\mathbf{A})$.

A expressão do mRNA do Flt-1 apresentou níveis basais durante 0 desenvolvimento, ocorrendo um aumento aos 6 meses pós-natal, esta fase não apresentou diferenças estatísticas, e um pico de elevação com 1 ano de idade com diferenças estatísticas significantes $(p<0,05)$ (Gráfico 2 - B).

A expressão do mRNA do KDR no timo de gatos obedeceu a um padrão de diminuição aos 45 dias de gestação chegando a um pico de diminuição aos 55 dias, começando a aumentar os níveis de expressão até 6 meses pós-natal e até atingir uma significativa elevação $(p<0,05)$ à idade de 1 ano (Gráfico 2 - C). 
Gráfico 2 - Expressão relativa do mRNA do VEGF (A), Flt-1 (B) e KDR (C) no timo de gato ao longo de seu desenvolvimento (35, 45, 55, 65 dias de gestação), maturação ( 6 meses pós-natal) e fase de involução ( 1 ano de idade). Gráficos representam a média \pm EPM de três animais. Letras diferentes correspondem a diferenças significativas $(p<0,05)$ entre os grupos.
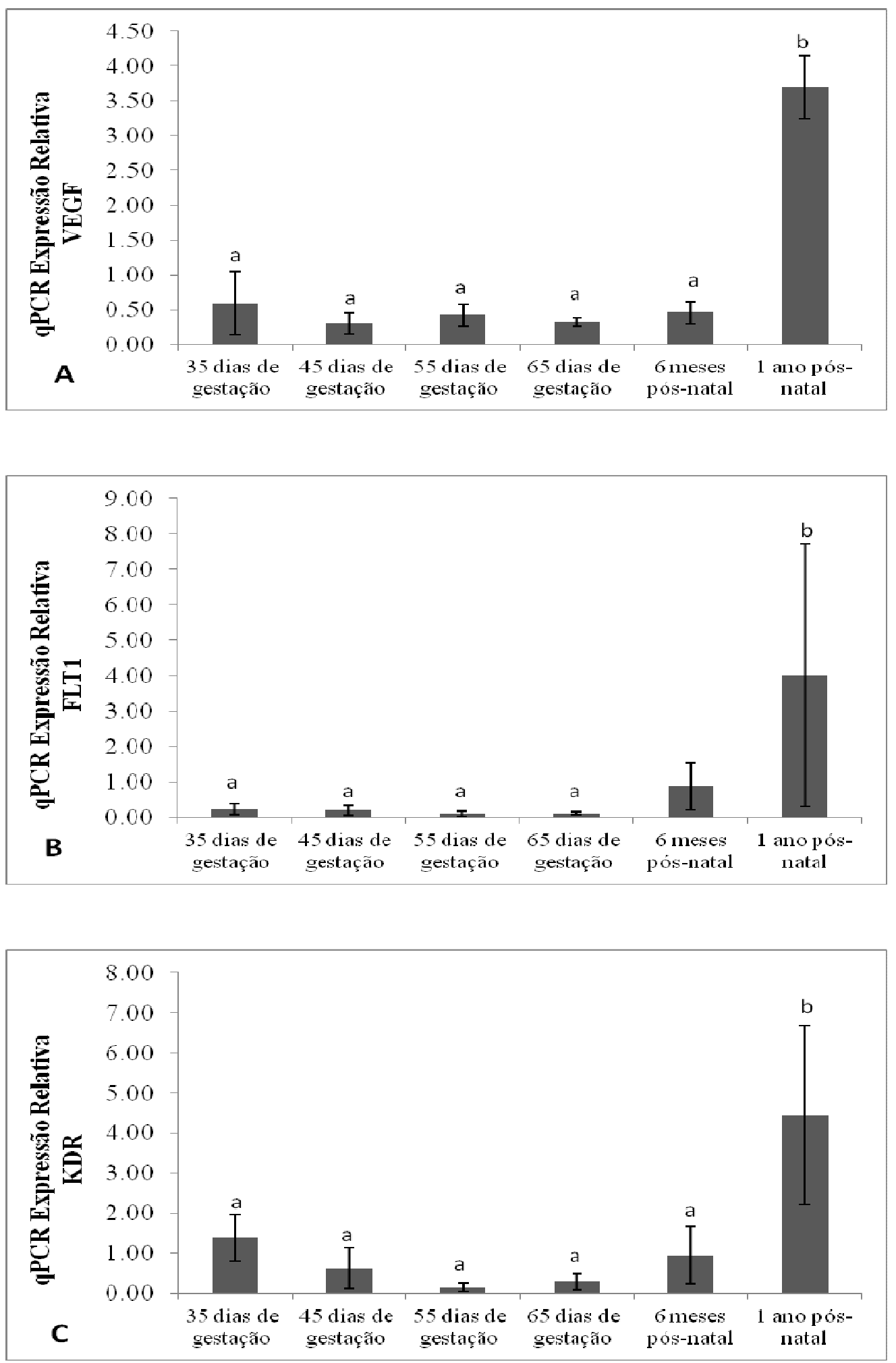


\subsection{IMUNOLOCALIZAÇÃO DO VEGF E SEUS RECEPTORES (FIt-1 e KDR)}

As proteínas do VEGF-A, KDR e Flt-1 foram identificadas no timo de gatos em todas as fases do desenvolvimento, pré-natal e pós-natal, foram localizadas no citoplasma de células epiteliais, células endoteliais e no interior dos corpúsculos tímicos.

A reação positiva para o VEGF-A foi observada em uma rede de células epiteliais na região subcapsular (Figura 5-A), também em células epiteliais isoladas na região do córtex (Figura 5- B e C) e em quase todas as células epiteliais da região medular (Figura 5 -D). Todos os corpúsculos de Hassal apresentaram marcação positiva.

Nos animais de 6 meses pós -natal e 1 ano de idade a imunomarcação das células epitelias foi mais rara (Figura 5 - E e F).

A imunomarcação do KDR foi expressa em quase todas as faixas etárias (Figura 6- A, B, D e E), com uma diferença aos 55 dias de gestação (Figura 6- C), apresentando imunomarcação menos frequente nas células epiteliais quando comparada com as outras faixas etária.

Observamos corpúsculos tímicos imunomarcados aos 45 dias de gestação (Figura 6-B), assim como aos 6 meses e 1 ano pós-natal (Figura 6- E e F). Também observamos imunomarcação das células epiteliais aos 6 meses e 1 ano de idade pós-natal. As células endoteliais apresentaram imunomarcação positiva, ao redor dos vasos.

$\mathrm{Na}$ imunolocalização do Flt-1 foi observado células epiteliais imunomarcadas nas faixas etárias pré-natais e 1 ano de idade (Figura 7- A, B, C, D e F). Aos 6 meses pós-natal raras células epitelias imunomarcadas foram detectadas (Figura 7E). Os vasos tímicos apresentaram células endoteliais imunomarcadas, assim como os corpúsculos tímicos também apresentaram imunomarcação (Figura 7 - F). 
Figura 5- Fotomicrografias da localização da proteína VEGF-A em timo de gatos. A: feto com 35 dias de desenvolvimento, $200 \mu \mathrm{m}$. B: feto com 45 dias de desenvolvimento, $200 \mu \mathrm{m}$. C: feto com 55 dias de desenvolvimento, $50 \mu \mathrm{m}$. D: feto com 65 dias de gestação, $50 \mu \mathrm{m}$. E: 6 meses pós-natal, $20 \mu \mathrm{m}$. F: 1 ano de idade, $50 \mu \mathrm{m}$. Legenda: CE - célula endotelial, CTcorpúsculo tímico, M -zona medular, seta - cápsula tímica
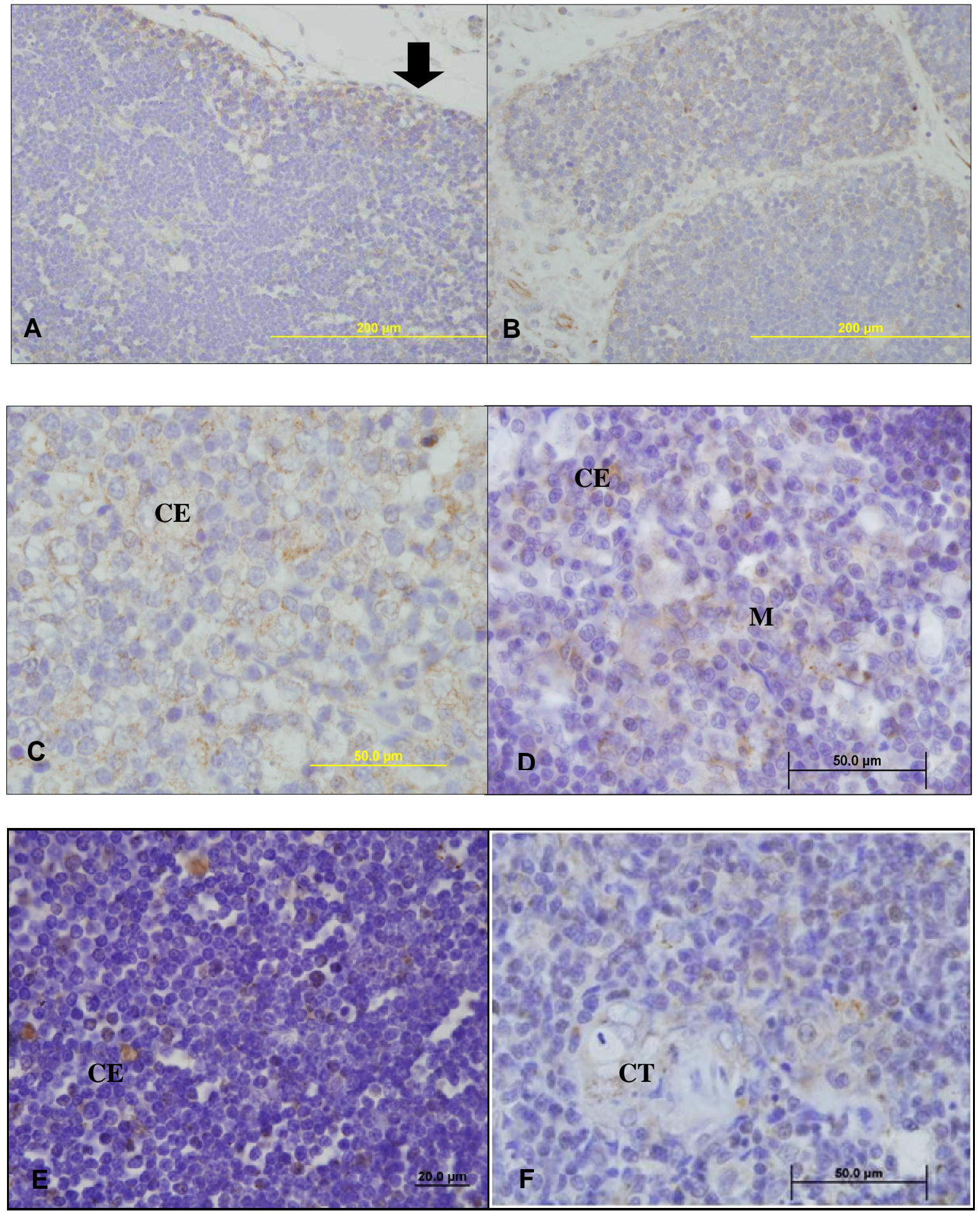
Figura 6 - Fotomicrografias da localização da proteína KDR em timos de gatos. A: feto com 35 dias de desenvolvimento, $50 \mu \mathrm{m}$. B: feto com 45 dias de desenvolvimento, $50 \mu \mathrm{m}$. C: feto com 55 dias de gestação, $50 \mu \mathrm{m}$. D: feto com 65 dias de desenvolvimento $50 \mu \mathrm{m}$. E: gato com 6 meses pós-natal, $20 \mu \mathrm{m}$. F: gato com 1 ano de idade, $50 \mu \mathrm{m}$. Legenda: CE - célula endotelial, CT- corpúsculo tímico, V- Vaso, seta célula endotelial, * : Célula migratória.
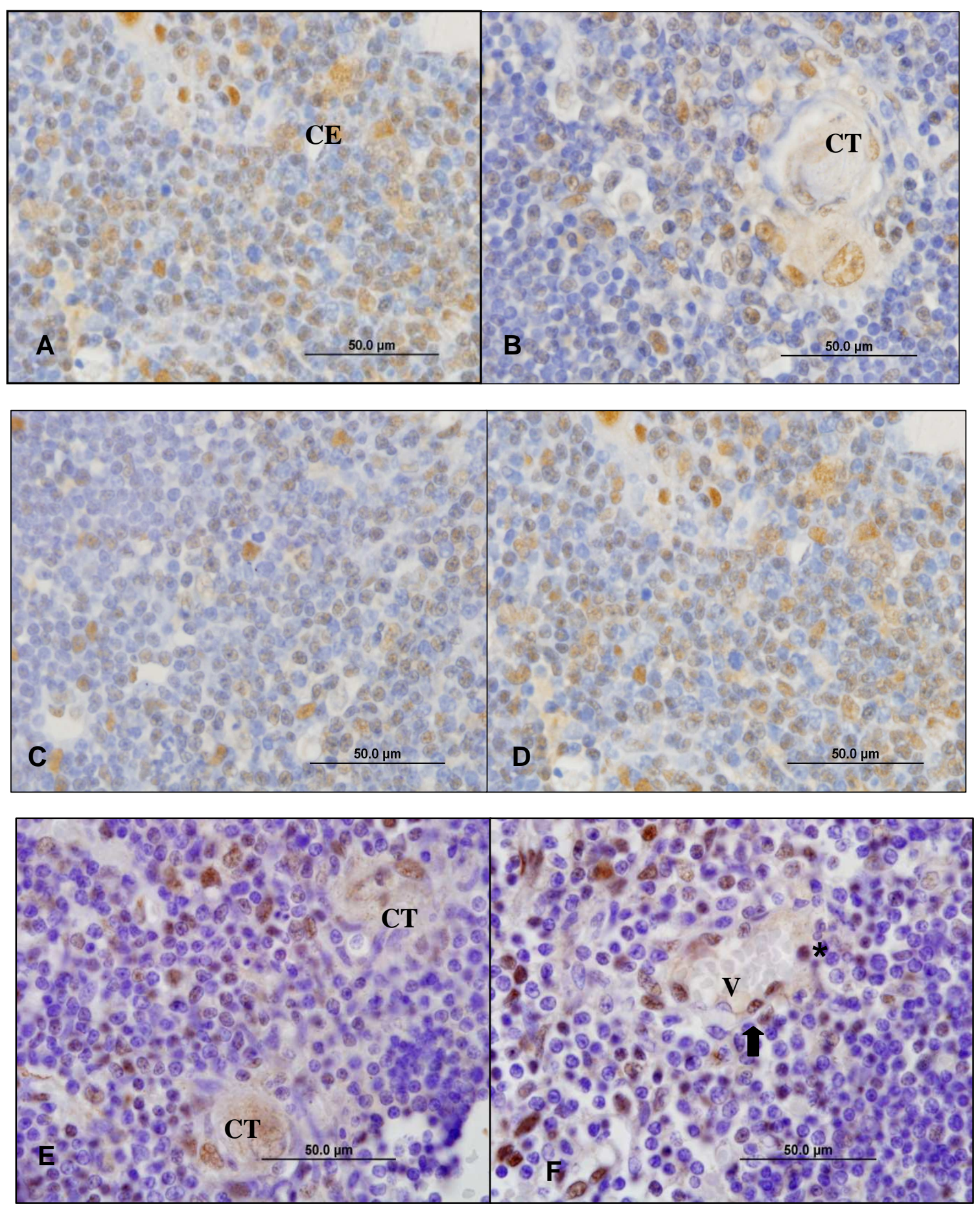
Figura 7 - Fotomicrografias da localização da proteína Flt-1 em timos de gatos. A: feto com 35 dias de desenvolvimento, $50 \mu \mathrm{m}$. B: feto com 45 dias de desenvolvimento, $50 \mu \mathrm{m}$. C: feto com 55 dias de gestação, $50 \mu \mathrm{m}$. D: feto com 65 dias de gestação, $50 \mu \mathrm{m}$, E: 6 meses pósnatal, $20 \mu \mathrm{m}$. F: 1 ano de idade, $50 \mu \mathrm{m}$. Legenda: V: Vaso; CE: Célula epitelial; Seta: Célula endotelial.
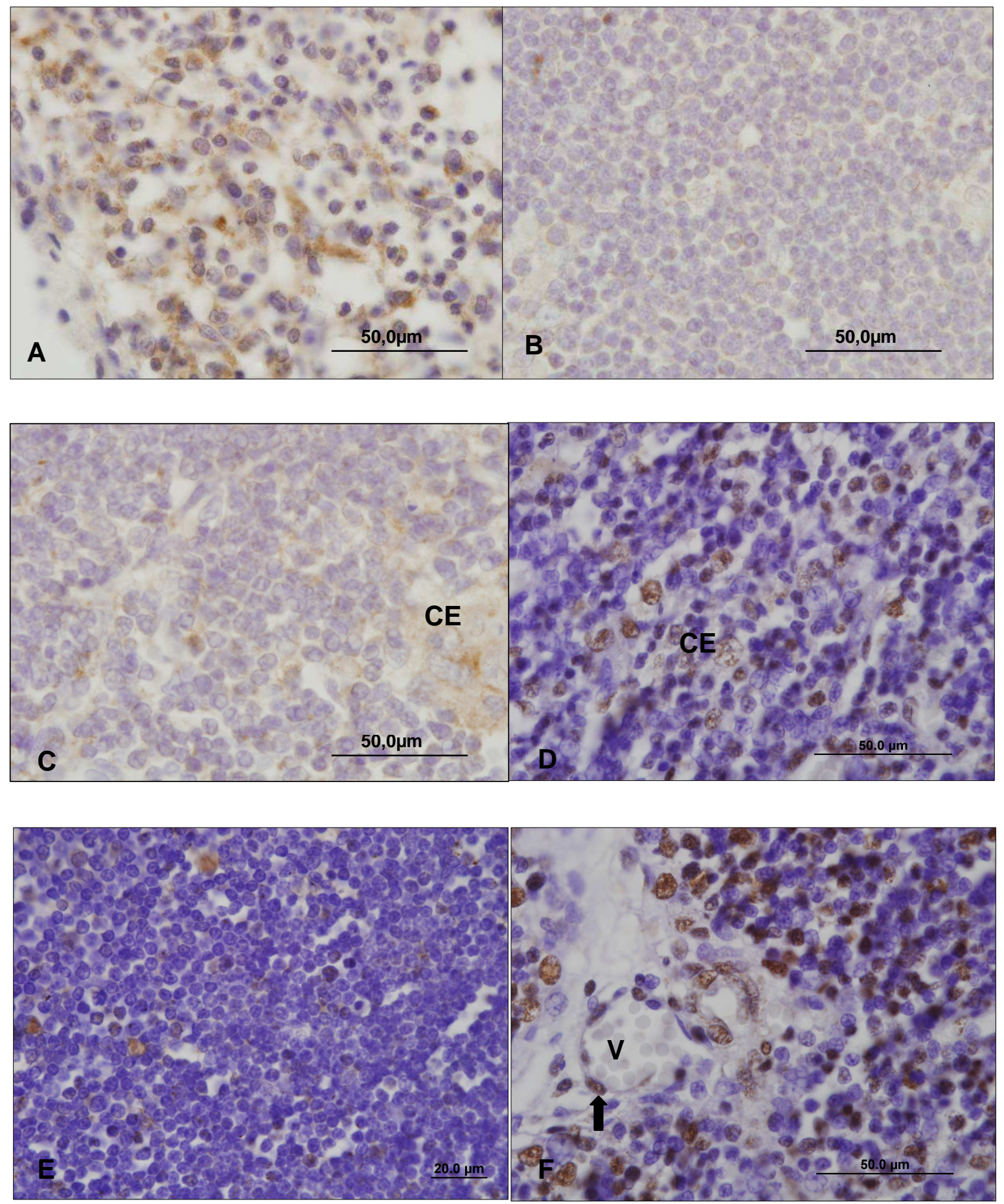


\subsection{MICROSCOPIA ELETRÔNICA DE VARREDURA (MEV)}

A MEV foi realizada em timo de fetos de gatos de $35,45,55,65$ dias de gestação e nos animais de 6 meses e 1 ano pós-natal.

Observou-se na varredura que o aspecto macroscópico do timo, de feto de gato, aos 35 dias apresentou-se em fase de organização estrutural, envolto por uma cápsula de tecido conjuntivo (Figura 8 - A).

Aos 45 dias de gestação a apresentação macroscópica do timo é de um órgão maduro, com seu processo de lobação estruturado e bem definido (Figura 8 B).

O tecido conjuntivo da cápsula adentra o parênquima dividindo o timo em lobos, juntamente com este tecido evidenciamos vasos e nervos (Figura 9-A e B).

O microambiente tímico também acompanha a organização do órgão, uma vez que o desenvolvimento de um linfócito $T$ está intimamente ligado a este microambiente. Este tem a função de propiciar um local adequado para que ocorra a maturação linfocitária. As células reticulares epiteliais se apresentam em grande quantidade, emitem prolongamentos citoplasmáticos que ajudam a criar um ambiente tímico adequado. (Figura 10 - A, B e C; Figura 11 - A e B).

A diferenciação dos linfócitos também acontece dentro de complexos linfoepiteliais com células chamadas de "nurse", complexo TNC ("thymic nurse cells"). Essa diferenciação é demonstrada pela expressão de microvilos na superfície dos timócitos (Figura 12 - A e B).

Dando continuidade a descrição das estruturas tímicas, observamos os corpúsculos tímicos (CT) que são estruturas específicas do timo, normalmente localizados em região medular e são formados por células epiteliais que se dispõem de forma concêntrica (Figura 13-A e B).

No parênquima tímico observamos uma rede de vasos tortuosos irrigando o interior do órgão (Figura $13-\mathrm{C}$ ). Em animais adultos observamos uma camada de células adiposas próximas à cápsula e aglomerados de timócitos (Figura 13-D) 
Figura 8 - Fotomicrografias do timo de gato. A- Fragmento de órgão aos 35 dias de gestação. Observam-se lóbulos em processo de formação e grande presença de tecido conjuntivo interlobular. Barra: $100 \mu \mathrm{m}$. B- Fragmento de órgão aos 45 dias gestacionais. Maior organização e desenvolvimento da lobulação tímica característica. MEV. Barra: $200 \mu \mathrm{m}$
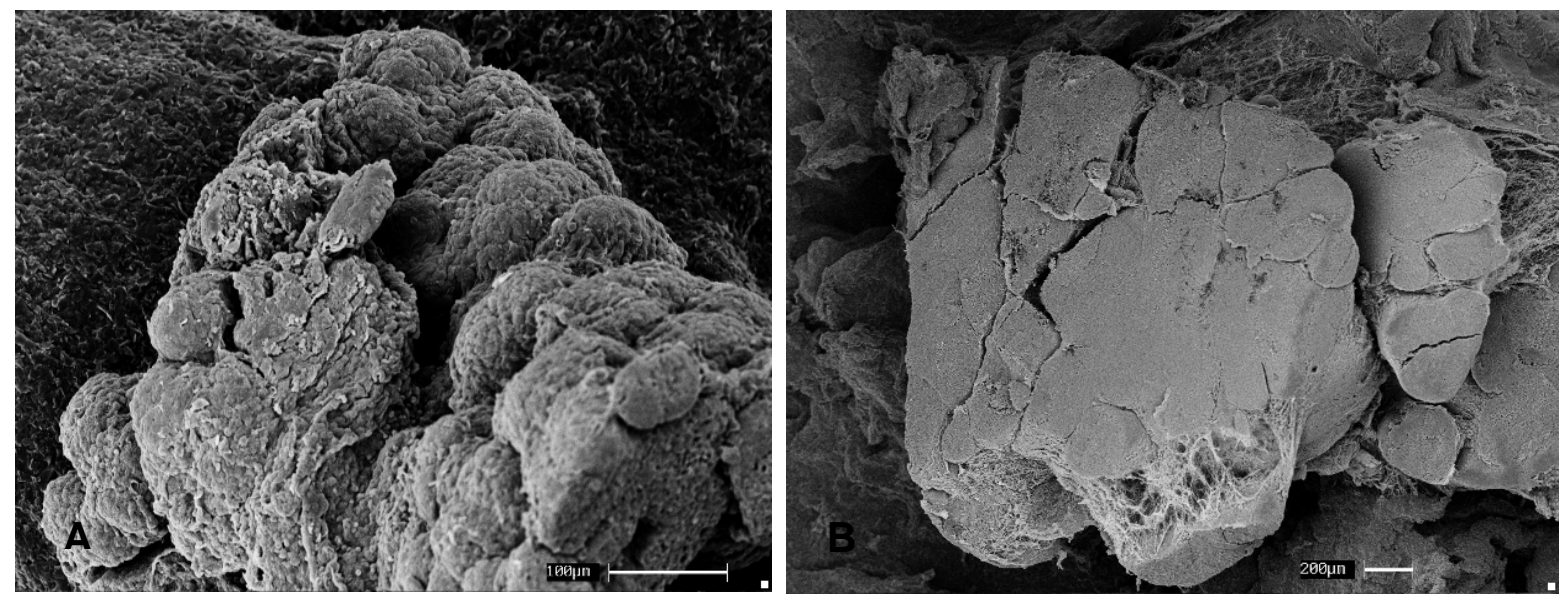

Figura 9 - Fotomicrografias do timo de gato de aproximadamente 45 dias de gestação. A- Região de septo interlobular. A seta evidencia um vaso em região de septo interlobular. MEV. Barra: $20 \mu \mathrm{m}$. B- Indicados artéria, veia e nervo em região de septo interlobular. MEV. Barra: $100 \mu \mathrm{m}$
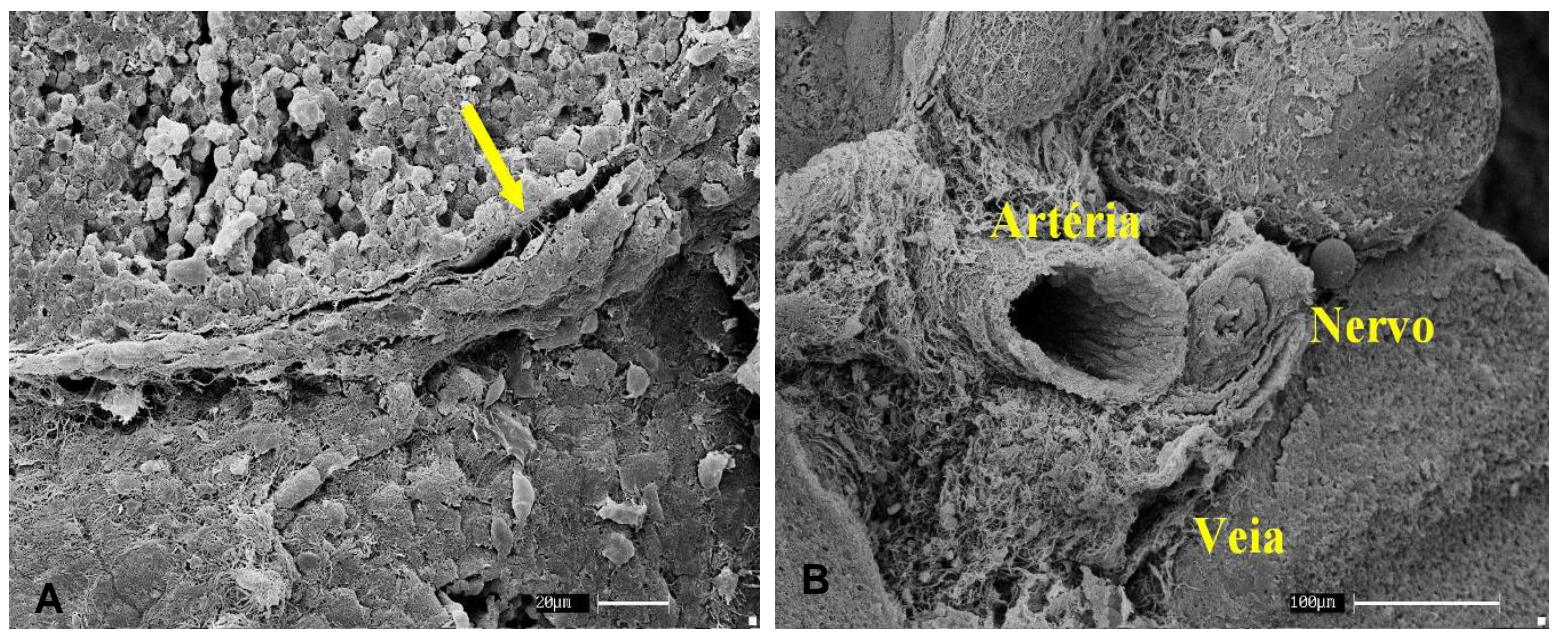
Figura 10 - Fotomicrografias do timo de feto de gato de aproximadamente 45 dias de gestação. É evidente a presença de linfócitos de diferentes graus de maturação, ou seja, timócitos de diferentes tamanhos, envoltos por prolongamentos de células reticulares epiteliais e fibras de tecido conjuntivo em região medular. MEV. A- Barra: $10 \mu \mathrm{m}$. B- Barra: $10 \mu \mathrm{m}$. C- Barra: 10 um
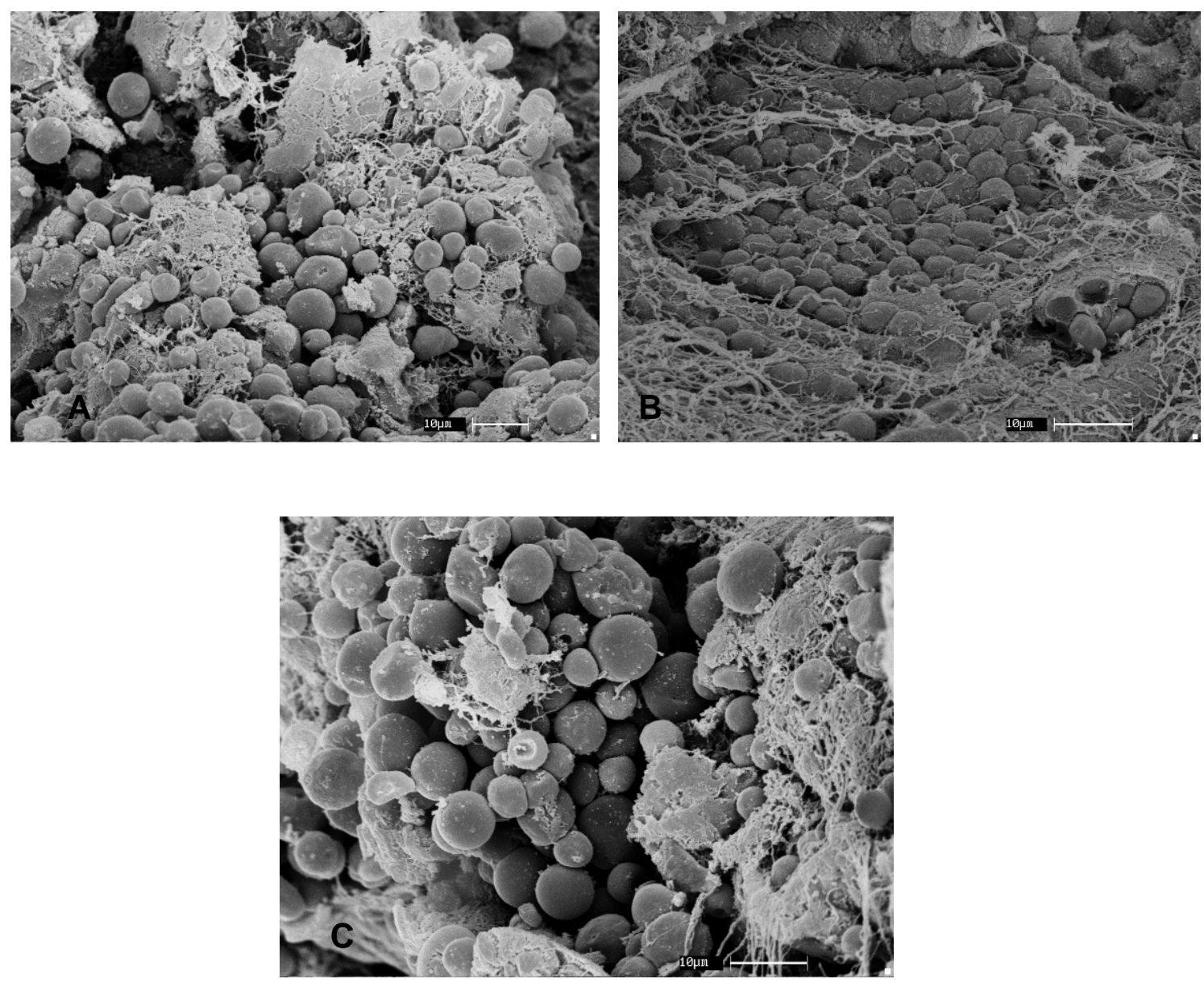
Figura 11- Fotomicrografias do timo de feto de gato de aproximadamente 55 dias de gestação. Células epiteliais estão densamente empilhadas, deixando pouco espaço extracelular. Estas células possuem extensões citoplasmáticas curtas. MEV. Figuras A e B - Barra: 10 $\mu \mathrm{m}$
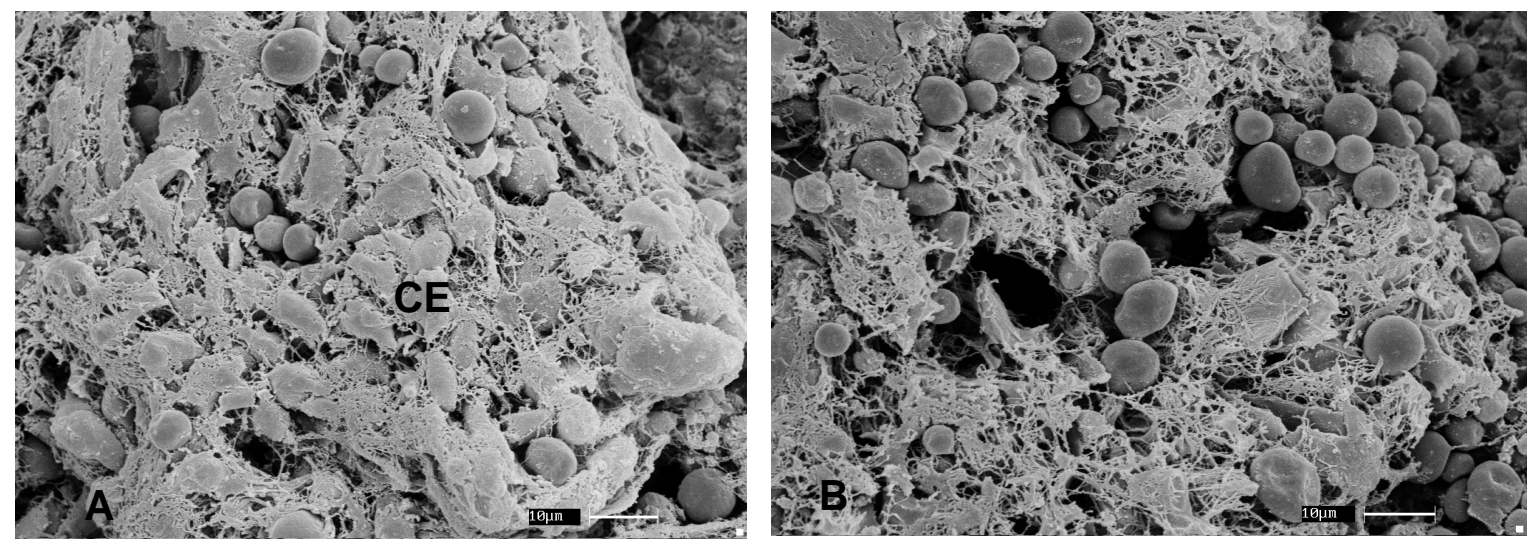

Figura 12- A: Fotomicrografias do timo de feto de gato de aproximadamente 55 dias de gestação. Um complexo linfoepitelial parecido com o "thymic nurse cell" (TNC) onde ocorre a diferenciação dos linfócitos $T$, esta diferenciação é demonstrada pela expressão de microvilos nos timócitos. Na figura B observa-se um timócito, expressando os microvilos, que está entrando ou saindo do complexo TNC. MEV. A e B: Barra $3 \mu \mathrm{m}$
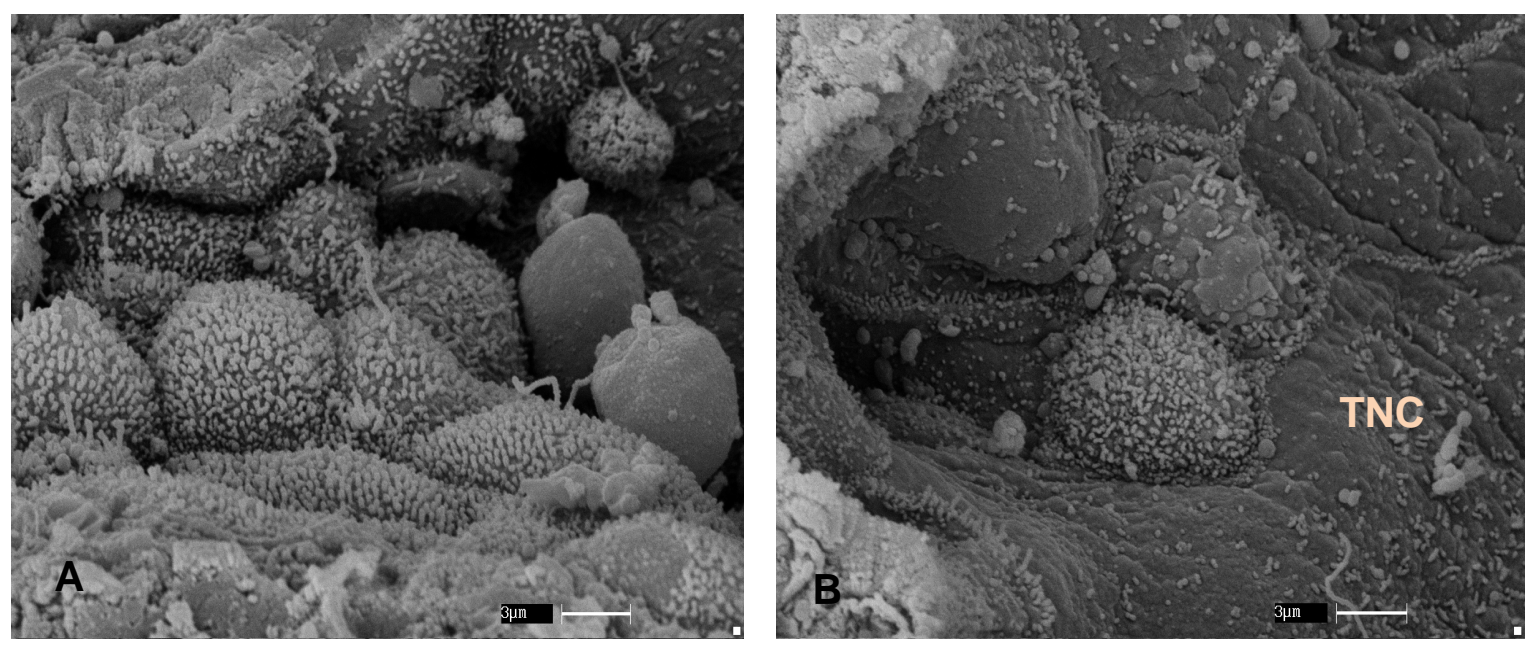
Figura 13 - A e B: Fotomicrografias do timo de feto de gato de aproximadamente 6 meses pós-natal. Evidenciando corpúsculos tímicos (CT). Na figura $C$ observam-se vasos (V) tortuosos do parênquima tímico, animal com 6 meses de idade pós-natal. A, B e C: Barra $30 \mu \mathrm{m}$. Na figura $D$ evidenciam-se adipócitos (Ad) e aglomerados de timócitos a esquerda da foto, seta indica a cápsula tímica, animal acima de 1 ano de idade. MEV. Barra: $20 \mu \mathrm{m}$
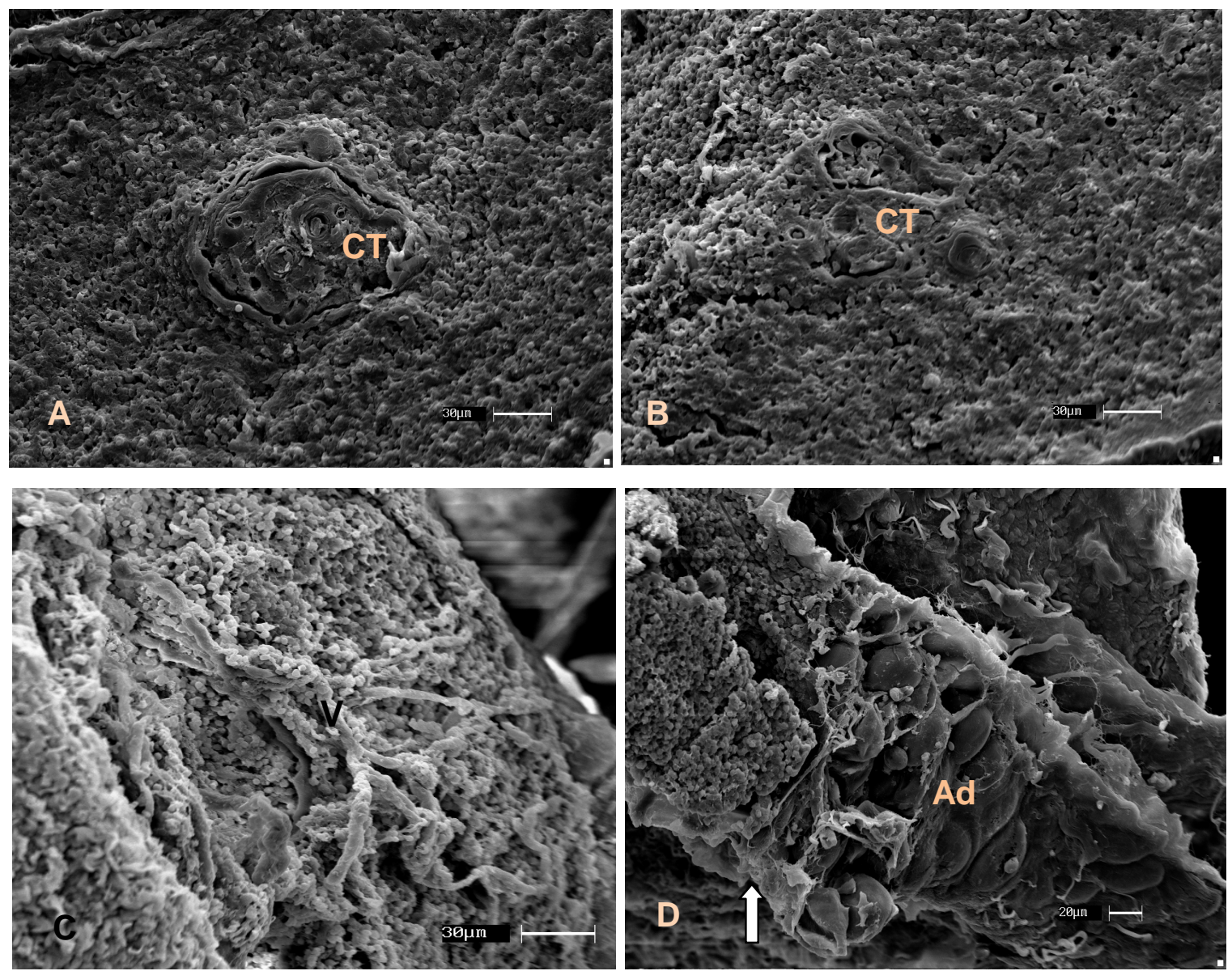
DISCUSSÃO 


\section{DISCUSSÃO}

O trabalho em questão foi bem sucedido em trazer novas informações concernentes ao desenvolvimento e involução do timo com foco em sua vascularização.

Os grupos etários foram estabelecidos com a finalidade de definir padrões do desenvolvimento do órgão em fase pré e pós-natal.

Como é de nosso conhecimento no timo, os precursores derivados da medula óssea sofrem um complexo processo de maturação, que ocorre à medida que os timócitos migram no microambiente tímico formando uma rede tridimensional composta de diferentes tipos celulares. Estas células microambientais interagem com os timócitos, provendo sinais que regulam o desenvolvimento intratímico normal de células $T$. Estes sinais são liberados em nichos do microambiente tímico, nos quais um determinado tipo celular apresenta um padrão de sinalização específico, e influenciam determinados estágios específicos de diferenciação/migração dos timócitos. Para que o órgão consiga se desenvolver e exercer a sua função, a vascularização é de notável importância.

O processo de angiogênese e vasculogênese precisa ocorrer adequadamente e o estudo do comportamento dos vasos no órgão pode ajudar a elucidar aspectos relacionados a processos patológicos e de ordem filogenética, como a involução tímica.

Em nosso trabalho os achados macroscópicos foram semelhantes aos relatados por Daschinger (1983), que descreveu que o mesmo possui coloração rósea-pálido e aspecto visivelmente lobular. A lobação do órgão foi semelhante aos relatos de Daschinger (1983) e Silva et al. (2001) que relatam que o órgão apresenta duas porções, torácica e cervical sendo que a última apresentou-se fina e estreita.

A localização do órgão foi observada na região do mediastino cranial ao coração e ventral a traqueia, semelhantes aos relatos de Daschinger (1983).

A forma deste órgão variou individualmente entre fetos da mesma ninhada característica também apontada por Daschinger (1983) e o lobo direito apresentouse menor que o esquerdo, como descrito por Hudson e Hamilton (1993).

Kato (1997) e Junqueira e Carneiro (1999) relataram que durante o desenvolvimento do timo, ramos vasculares penetram no interior do parênquima 
acompanhando o tecido conjuntivo, formando um espaço de tecido conjuntivo perivascular, fato este observado em nosso trabalho. Em detalhe, verificamos que as arteríolas ramificam-se e acompanham os septos conjuntivos, formando capilares que penetram na região cortical, depois se dirigem para a região medular onde desembocam em vênulas, que depois confluem para formar veias e penetram nos septos conjuntivos e saem do timo pela cápsula.

Em um estudo sobre parâmetros estereológicos da vascularização do timo em suínos, sem distinção de sexo, Machado (2010), constatou que as variáveis $S_{v}$ e $N_{v}$ da região cortical e junção corticomedular sofreram uma diminuição no período de desenvolvimento fetal para apresentar um aumento em período próximo ao nascimento, concordando com nossos achados na variável $\mathrm{N}_{\mathrm{v}}$. Com relação a variável $S_{v}$ observamos este comportamento nas fêmeas diferindo dos machos que apresentaram um comportamento oposto. Pode ser explicado pela influência dos hormônios andrógenos que possui ação de antiproliferação no timo (OLSEN; KOVACS, 1996).

Agreste (2010) estudou os aspectos estereológicos da vascularização do timo em cães, seus parâmetros $L_{v}$ e $N_{v}$ apresentaram uma diminuição após os 6 meses pós-natal possuindo identificação positiva com os nossos parâmetros que também apresentaram esta diminuição aos 6 meses pós-natal.

No presente estudo observamos que a variável a $N_{v(v a s c)}$ apresentou um comportamento semelhante a expressão do mRNA do KDR no tecido tímico, com uma diminuição após os 35 dias pré-natal até os 55 dias pré-natal seguida de um aumento. Vale ressaltar que o KDR age ligado ao VEGF influenciando a formação de vasos.

O mecanismo de vascularização compreende a vasculogênese e angiogênese que tem início no desenvolvimento embrionário. Um dos mais potentes agentes angiogênicos é o VEGF-A que possui a habilidade de aumentar a permeabilidade vascular e promover a proliferação de células endoteliais.

Cimpean et al. (2007) analisou o timo de pacientes humanos, entre 1 mês e 50 anos de idade, com propósito de estudar o padrão e localização da expressão protéica do VEGF no timo normal e nos casos de timoma. Observou que nos timos normais os citoplasmas das células epiteliais, com distribuição subcapsular, se apresentaram positivas para a marcação do VEGF e também as células epiteliais 
dos corpúsculos tímicos, corroborando com as nossas observações em gatos domésticos.

O desenvolvimento da rede vascular do timo depende da alta concentração de VEGF nas células epiteliais deste e, após o nascimento, os níveis de VEGF diminuem (Raica et al., 2006). A imunomarcação positiva para o VEGF em nossas observações também ficou restrita a maioria das células epiteliais abaixo da cápsula e dispostas em redes, com poucas células imunomarcadas na região do córtex.

Identificamos timócitos imunomarcados para o VEGF, KDR e Flt-1 e Cuddihy et al. (2009) também observaram timócitos CD4 e CD8 imunomarcados para VEGF indicando que estão em processo de maturação.

A manutenção da expressão proteica do VEGF nos corpúsculos tímicos após o nascimento está correlacionada ao seu envolvimento na maturação linfocítica. Esses dados reforçam a hipótese que os corpúsculos tímicos são estruturas ativas que participam na seleção e maturação na vida pós-natal (WATANABE et al., 2005). Corpúsculos tímicos nas idades pré-natais expressaram VEGF em todas as células epiteliais do centro até a periferia, nos corpúsculos tímicos pós-natais também observamos imunomarcação positiva em nosso trabalho. Os receptores do VEGF, Flt-1 e KDR também marcaram os corpúsculos tímicos nas fases pré e pós-natais estando relacionados à maturação e migração dos linfócitos do córtex.

Enquanto o KDR possui a função de induzir proliferação das células endoteliais, o Flt-1 possui a função de diferenciação e organização vascular (DOUGHER, 1999). Em nossos resultados os timócitos também expressaram marcação para VEGF e seus receptores indicando que os timócitos sofrem influência deste fator de crescimento.

Shen (2008) trabalhou com formação de tecidos funcionais e enfrentava dificuldades porque a capacidade de transportar oxigênio e nutrientes nestes tecidos era limitada. Induzir uma vascularização dentro destes tecidos era um ponto chave para aumentar a sobrevivência tanto in vitro como in vivo. Concluiu-se que o VEGF injetado promoveu penetração e proliferação das células endoteliais promovendo um esqueleto de vascularização. Podemos inferir, baseado em nossos resultados, que a expressão do mRNA do VEGF no desenvolvimento tímico é importante para o desenvolvimento vascular. 
No período de 1 ano de idade a expressão do mRNA do VEGF e seus receptores tem um aumento significativo, coincidindo com a diminuição do $\mathrm{N}_{\text {vasc }}$ e do $\mathrm{N}_{\mathrm{v} \text { (vasc) }}$ podendo causar um estado de hipóxia no órgão levando a um aumento compensatório de sistema VEGF. A hipóxia induz ajustes de expressão do Flt-1 e KDR (GERBER et al., 1997). O próprio VEGF é capaz de aumentar ou diminuir a expressão de seus receptores (OLSZEWSKA-PAZDRAK et al.,2009).

A diferenciação das células tímicas ocorre ao longo de sua migração no microambiente altamente compartimentalizado, formado por células de diferentes tipos, como células epiteliais, macrófagos, dendríticas, fibroblastos, e componentes da matriz extracelular. O processo de desenvolvimento das células T é comumente descrito como um fluxo linear sucessivo por compartimentos cada vez mais diferenciados, onde as células se apresentam em estágios diferentes de maturação em porções distintas do órgão (SOLAROVIĆ; LALIĆ; LEPOSAVIĆ, 2004). Em nosso trabalho evidenciou-se timócitos de diferentes tamanhos, o que nos permite inferir que estes se encontram em diferentes estágios de maturação em um microambiente variado de tipos celulares.

Em um estudo realizado por Anderson et al., 1998, descreveu-se uma técnica para mensurar a proliferação das células epiteliais tímicas de fetos de camundongos por citometria de fluxo e examinou-se os efeitos de diferentes culturas in vitro na função celular epitelial. Os resultados demonstraram que o aumento do tamanho tímico durante o desenvolvimento é acompanhado pela proliferação no compartimento epitelial, que também foi observado por outros métodos em nosso trabalho. Contudo a proporção das células epiteliais declinou durante a embriogênese. Este declínio na proliferação é também encontrado nas culturas de órgãos e em culturas esgotadas de células linfoides, sugerindo que o ciclo celular das células epiteliais tímicas é independente da população linfoide. Quando as células epiteliais foram cultivadas in vitro como agregados tridimensionais, estas mantiveram a habilidade de auxiliar na maturação timocítica. Em contraste, quando cultivadas em monocamadas bidimensionais as células epiteliais perderam a habilidade de auxiliar na seleção positiva, causando uma redução na expressão genética e reduzindo sua habilidade em reagregar estruturas. Podemos inferir que com o processo de perda de células epiteliais, pela substituição do parênquima por 
células adiposas, causa uma descompartimentalização tímica que participa do processo de involução do órgão.

Em nossos resultados pelas técnicas de imuno-histoquimica e MEV observamos grande quantidade de células epiteliais reticulares. $O$ desenvolvimento das células $\mathrm{T}$ intratímicas requer um microambiente estromal íntegro no qual as células epiteliais reticulares constituem a maior parte (RITTER; CRISPE, 1992; BOEHM; BLEUL, 2006). O desenvolvimento consiste em vários processos que requerem a re-localização dinâmica dos timócitos em desenvolvimento para dentro e fora de múltiplos nichos tímicos (TAKAHAMA, 2006).

O córtex fornece o microambiente necessário para a seleção positiva de timócitos imaturos e a região medular para seleção negativa de células $T$ autoreativas (RITTER; CRISPE, 1992; BOEHM; BLEUL, 2006).

Em um estudo realizado por Lacerda (2008), foram identificados genes diferencialmente expressos entre células epiteliais tímicas corticais e medulares. Alguns genes fazem parte da regulação neuroendócrina do epitélio tímico, como por exemplo, timopoietina e receptores hormonais; outros como a VCAM-1 (molécula de adesão celular vascular) e fibronectina, participam da adesão e migração de timócitos no microambiente tímico. A identificação de tais genes contribuiu para o entendimento dos sinais fornecidos por nichos microambientais aos timócitos em desenvolvimento. Estes sinais geram a comunicação timócito/microambiente que é bilateral (conceito de cross-talk). O que implica que a interação com o timócito deva modular a expressão gênica no epitélio tímico.Podemos inferir que o timócito pode influenciar na expressão do sistema VEGF no órgão.

É pouco conhecido como o estrogênio interfere no desenvolvimento timocítico. Lin Li et al. (2002b) observou em camundongos ArKO, deficientes de aromatase, que é uma enzima essencial para a síntese de estrogênio, que os timos desses animais apresentava regressão tímica e redução da celularidade, sugerindo que o estrogênio auxiliaria no desenvolvimento e maturação dos timócitos.

O papel da vascularização tímica e o processo de involução do órgão estão interligados e o mecanismo de como isso ocorre ainda está sendo elucidado.

Sabemos que as células epiteliais, juntamente com os fatores de crescimento e a vascularização possuem funções diversas, contudo possuem uma única função em comum, proporcionar um microambiente para a maturação dos linfócitos. E que a 
vascularização acompanha o processo de desenvolvimento e involução do órgão sofrendo influências dos fatores angiogênicos e das células presentes. 
CONCLUSÃO 


\section{CONCLUSÃO}

Com os resultados deste trabalho podemos concluir que:

A curva de crescimento vascular obedece a um padrão de desenvolvimento e involução do órgão.

D O sistema VEGF e seus receptores Flt-1 e KDR foram observados nas células endoteliais, nos corpúsculos tímicos e nas células epiteliais do timo durante seu desenvolvimento e período pós-natal.

> A expressão do mRNA do VEGF e seus receptores Flt-1 e KDR apresentaram um padrão de expressão diferenciados em período pré-natal e pós-natal. 
REFERÊNCIAS 


\section{REFERÊNCIAS}

AGRESTE, F. R. Quantificação da vascularização em cães. 2005. 104 p. Dissertação (Mestrado em Anatomia dos Animais Domésticos) - Faculdade de Medicina Veterinária e Zootecnia, Universidade de São Paulo, São Paulo, 2005

AYRES, M.; AYRES JR., M.; AYRES, D. L.; SANTOS, A. S. BioEstat 3.0. Aplicações estatísticas nas áreas das ciências biológicas e médicas. Belém: Mamirauá/MCTCNPq/ Conservation International, 2003, 291 p.

ANDERSEN, B. B.; PAKKENBERG, B. Stereological quantitation in cerebella from people with schizopherenia. Brazilian Journal Psychiatry, v. 182, p. 354-361, 2003.

ANDERSON, G.; MOORE, N. C.; OWEN, J. J. T.; JENKINSON, E. J. Cellular interactions in thymocyte development. Annual Review of Immunolgy, v. 14, p. 73, 1996.

ANDERSON, M.; ANDERSON, S. K.; FARR, A. G. Thymic vasculature: organizer of the medullary epithelial compartment? International Immunology, v. 12, n. 7, p.1105-1110, 2000.

ANDERSON, K. M.; MOORE, N. C.; McLOUGHLIN, D. E. J.; JENKINSON, E. J.; OWEN, J. J. T. Studies on thymic epithelial cells in vitro. Developmental and Comparative Immunology, v. 22, n. 3, p. 367-377, 1998.

BANKS, J. W. Sistema linfático e imunitário. In: .Histologia veterinária aplicada. 2. ed. São Paulo: Editora Manole, 1992. p. 370-390.

BAR-DAYAN, Y.; AKEK, A.; BAR-DAYAN, Y.; GOLDBERG, I.; KOPOLOVIC, J. Proliferation, apoptosis and thymic involution. Tissue\&Cell, v. 31, n. 4, p. 391-396, 1999.

BARROSO, C. E. Estudo quantitativo da vascularização do timo em gatos. 2007. 81 p. Dissertação (Mestrado em Anatomia dos Animais Domésticos) Faculdade de Medicina Veterinária e Zootecnia, Universidade de São Paulo, São Paulo, 2007.

BATES, D. O.; HARPER, S. J. Regulation of vascular permeability by vascular endothelial growth factors. Vascular Pharmacology, v. 39, p. 225-237, 2002. 
BERISHA, B.; SCHAMS, D.; KOSMANN, M.; AMSELGRUBER, W.; EINSPAINER, R. Expression and Tissue Concentration of Vascular Endothelial Growth Factor, Its Receptors, and Localization in the Bovine Corpus Luteum During Estrous Cycle and Pregnancy. Biology of Reproduction, n. 63, p. 1106-1114, 2000.

BERNATCHEZ, P. N.; SOKER, S.; SIROIS, M. G. Vascular endothelial growth factor effect on endothelial cell proliferation, migration, and platelet-activating factos synthesis is FLK-1-dependent. The Journal of Biological Chemistry, Baltimore, v. 274, n. 43, p. 31047-31054, 1999.

BLEUL, C. C.; CORBEAUX, T.; REUTER, A.; FISCH, P.; MÖNTING, J. S. BOEHM, $\mathrm{T}$. Formation of a functional thymus initiated by a postnatal epithelial progenitor cell. Nature, v. 441, n. 22, p. 992-996, 2006.

BOCKMAN, D. E. Development of the thymus. Microscopy Research and Technique, v. 38, p. 209-215, 1997.

BOEHM, T.; BLEUL, C. C. Thymus-homing precursors and the thymic microenvironment. Review: Trends in Immunology, v. 27, n. 10, p. 477-484, 2006.

BOMBONATO, P. P. Aspectos da morfologia, topografia e vascularização arterial do timo em fetos de búfalo. 1997. 88 p. Tese (Livre Docente) - Faculdade de Medicina Veterinária e Zootecnia, Universidade de São Paulo, São Paulo, 1997.

BOMBONATO, P. P.; SANTANA, M. I. S.; SILVA, F. O. C.; SEVERINO, R. S.; DRUMMOOND, S. S. Irrigação do timo de fetos de caprinos da raça Saanen: estudo comparativo. Brazilian Journal of Veterinary Research and Animal Science, v. 38, n. 5, p. 203-208, 2001.

BOONYAPRAKOB, U.; GADSBY, J. E.; HEDGPETH, V.; ROUTH, P.; ALMOND, G. W. Expression and localization of vascular endothelial growth factor and its receptors in pig corpora lutea during the oestrous cycle. Reproduction, v. 126, p. 393-405, 2003.

BRELINSKA, R.; MALENDOWICZ, L. K.; MALINSKA, A.; KOWALSKA, K. Characteristics of age-related changes in rat thymus: morphometric analysis and epithelial cell network in various thymic compartments. Biogerontology, v. 9, n. 2, p. 93-108, 2008. 
CAMPOS, D. B. Imunolocalização do VEGF, bFGF e seus receptores na placenta bovina e influência destes fatores sobre a produção de progesterona pelas células placentárias em cultura. 2005. 193p. Tese (Doutorado em Anatomia dos Animais Domésticos) - Faculdade de Medicina Veterinária e Zootecnia, Universidade de São Paulo, São Paulo,.

CAO, R.; ERIKSSON, A.; KUBO, H.; ALITALO, K.; CAO, Y.; THYBERG, J. Comparative evaluation of FGF-2, VEGF-A, and VEGF-C induced angiogenesis, lymphangiogenesis, vascular fenestrations, and permeability. Circulation Research, v. 94 , n. 5 , p. $664-670,2004$.

CAO, Y.; LINDEN, P.; SHIMA, D.; BROWNE, F.; FOLKMAN, J. In vivo angiogenic activity and hypoxia induction of heterodimers of placenta growth factor/vascular endothelial growth factor. Journal of Clinical Investigation, v. 98, n. 11, p. 25072511, 1996.

CIMPEAN, A. M.; RAICA, M.; ENCICA, S.; CORNEA, R.; BOCAN, V. Immunohistochemical expression of vascular endothelial growth factor A (VEGF), and its receptors (VEGFR1,2) in normal and pathological conditions of the human thymus. Annals of Anatomy, v. 190, p. 238-245, 2007.

COGGESHALL, R. E. A consideration of neural counting methods. Techniques, v. 15, n. 1, p. 9-13, 1992.

COGGESHALL, R. E.; LEKAN, H. A. Methods for determining numbers of cellsand synapses: a case for more uniform standards of review. The Journal of Comparative Neurology, v. 364, p. 6-15, 1996.

COULTAS, L.; CHAWENGSAKSOPHAK, K.; ROSSANT, J. Review - Endothelial cells and VEGF in vascular development. Nature, v. 438, p. 937-945, 2005.

CUDDIHY, A. R.; GE, S.; ZHU, J.; JANG, J. CHIDGEY, A.; THURSTON, G. BOYD, R.; CROOKS, G. M. VEGF-mediated cross-talk within the neonatal murine thymus. Blood, v. 113, n. 12, p. 2723-2731, 2009.

DASCHINGER, V. E. K. Zur Topographie und Blutgefäßversorgung des Thymus der neugeborenen Hauskatze (Felis silvestris $f$. catus). Zeitschrift fur versuchstierkunde, v. 25, p. 100-113, 1983. 
DEHOFF, R. T.; AIGELTINGER, E. H.; CRAIG, H. R. Experimental determination of the topological properties of three-dimensional microstructures. Journal of Microscopy, v. 95, p. 69-91, 1972.

DE VRIES, C.; ESCOBEDO, J. A.; UENO, H.; HOUCK, K.; FERRARA, N.; WILLIAMS, L. T. The fms-like tyrosine kinase, a receptor for vascular endothelial growth factor. Science, v. 255, n. 5047, p. 989-991, 1992.

DUERSTOCK, B. S.; BAJAJ, C. L.; BORGENS, R. B. A. A comparative study of the quantitative accuracy of three-dimensional reconstructions of spinal cord from serial histological sections. Journal of Microscopy, v. 210, n. 2, p. 138-148, 2003.

DOUGHER, M.; TERMAN, B. I. Autophosphorylation of KDR in the kinase domain is required for maximal VEGF-stimulated kinase activity and receptor internalization. Oncogene, v. 18, p. 1619-27, 1999.

DULL, R. O.; YUAN, J.; CHANG, Y. S.; TARBELL, J.; JAIN, R. K.; MUNN, L. L. Kinetics of placenta growth factor/vascular endothelial growth factor synergy in endothelial hydraulic conductivity and proliferation. Microvascular Research, New York, v. 61, n. 2, p. 203-210, 2001.

FERRARA, N. Vascular endothelial growth factor: basic science and clinical progress. Endocrine Reviews, v. 25, p. 581-611, 2004.

FERRARA, N.; CHEN, H.; DAVIS-SMYTH, T.; GERBER, H. P.; GYYEN T. N.; PEERS, D.; CHISHOLM, V., HILLAN, K. J.; SCHWALL, R. H. Vascular endothelial growth factor is essential for corpus luteum angiogenesis. Nature Medicine, v. 4, p. 336-340, 1998.

FERRARA, N.; HAUK, K.; JAKEMAN, L.; LEUNG, D. W. Molecular and biological properties of the vascular growth factor family of proteins. Endocrine Reviews, v. 13, p. 18-32, 1992.

FERRARA, N.; HENZEL, W. J. Pituitary follicular cells secrete a novel heparin-biding growth factor specific for vascular endothelial cells. Biochemical and Biophysical Research Communications, New York, v. 161, n. 2, p. 851-858, 1989.

FONH, G. H.; ROSSANT, J.; GERTSENSTEIN, M.; BREITMAN, M. L. Role of the Flt1 receptor tyrosine kinase in regulating the assembly of vascular endothelium. Nature, v. 376, p. 66-70, 1995. 
GABLER, C.; PLATH-GABLER, A.; KILLIAN, G. J.; BERISHA, B.; SCHAMS, D. Expression pattern of fibroblast growth factor (FGF) and vascular endothelial growth factor (VEGF) system members in bovine corpus luteum endothelial cells during treatment with FGF-2, VEGF or oestradiol. Reproduction of Domestic Animals, v. 39, p. 321-327, 2004.

GAGLIARDO, K. M. Número total de neurônios no gânglio mesentérico caudal de cães domésticos nas diferentes fases do desenvolvimento. Qual o papel da idade na população total e no tamanho dos neurônios?. 2003. 111 p. Tese (Mestrado em Ciências)- Faculdade de Medicina Veterinária e Zootecnia, Universidade de São Paulo, São Paulo, 2003.

GERBER, H. P.; CONDORELLI, F.; PARK, J.; FERRARA, N. Differential transcriptional regulation of the two vascular endothelial growth factor receptor genes. Flt-1, but not Flk-1/KDR, is up regulated by hypoxia. The Journal of Biological Chemistry, v. 272, p. 23659-23667, 1997.

GERBER, H. P.; VU, T. H.; RYAN, A. M.; KOWALSKI, J.; WERB, Z.; FERRARA, N. VEGF couples hypertrophic cartilage remodeling, ossification and angiogenesis during endochondral bone formation. Nature Medicine, v. 5, n. 6, p. 623-628, 1999.

GERSHWIN, L. J.; KRAKOWKA, S.; OLSEN, R. G. The lymphoid system and cells of the lymphoid system. In: Immunology and Immunopathology of domestic animals. 2. ed. Missouri: Morsby, 1995. p. 13-29.

GUETTY, R. Anatomia dos animais domésticos. 5. ed. Rio de Janeiro: Interamericana, 2000. v. 2, p. 1504-1568.

GUNDERSEN, H. J. G.; JENSEN, E. B. The eficiency of systematic sampling in stereology and its prediction. Journal of Microscopy, v. 147, p. 219-223, 1987.

GUNDERSEN , H. J. G.; BAGGER, P.; BENDTSEN, T. F.; EVANS, S. M.; KORBO, L.; MARCUSSEN, N.; MOLLER, A.; NIELSEN, K.; NYENGAARD, J. R.;

PAKKENBERG, B.; SORENSEN, F. B.; VESTERBY, A.; WEST, M. J.The new stereological tools: disector, fractionator, nuclear and point sampled intercepts and their use in pathological research and diagnosis. Acta Pathologica Microbiologica et Immunologica Scandinavica, v. 96, p. 857-881, 1998.

HALLIWELL, R. E. W.; GORMAN, N. T. Introduction. In: Veterinary clinical immunology. Philadelphia: Editora W. B. Saunder Co, 1989. p. 1-18. 
HENERY, C. C.; MAYHEW, T. M. The cerebrum and cerebellum of the fixed humans brain: efficient and unbiased estimates of volumes and cortical surfaces areas. Journal of Anatomy, v.167, p. 167-180, 1989.

HOLLÄNDER, G.; GILL, J.; ZUKLYS, S.; IWANAMI, N.; LIU, C.; TAKAHAMA, Y. Cellular and molecular events during early thymus development. Imunological Reviews, v. 209, p. 28-16, 2006.

HOWARD, C. V.; REED, M. G. Three-dimensional measurement in microscopy. In: Unbiased stereology. Oxford: bios Scientif Publishers, 1998. p. 246.

HUDSON, L. C.; HAMILTON, W. P. Atlas of feline anatomy for veterinarians. Filadélfia: W. B. Saunders Company, 1993.

JUNQUEIRA, L. C.; CARNEIRO, J. Sistema imunitário e órgãos linfáticos. In: Histologia básica. Rio de Janeiro: Guanabara Koogan, 1999. p. 220-240.

KAIPAINEN, A.; KORHONEN, J.; MUSTONEN, T.; VAN HINSBERGH, V. W.; FANG, G. H.; DUMONT, D.; BREITMAN, M.; ALITALO, K. Expression of the fms-like tyrosine kinase 4 gene becomes restricted to lymphatic endothelium during development. Proceedings of the National Academy of Sciences, v. 92, n. 8, p. 3566-3570, 1995.

KARKKAINEN, M. J.; MAKINEN, T.; ALITALO, K. Lymphatic endothelium: a new frontier of metastasis research. Nature Cell Biology, v. 4, p. E2-E5, 2002.

KATO, S. Thymic microvascular system. Microscopy Research and Technique, v. 38, p. 287-299, 1997.

KAZI, A. A.; JONES, J. M.; KOOS, R. D. Chromatin immunoprecipitation analysis of gene expression in the rat uterus in vivo: estrogen-induced recruitment of both estrogen receptor alpha and hypoxia-inducible factor 1 to the vascular endothelial growth factor promoter. Molecular Endocrinology, v. 19, n. 8, p. 2006-2019, 2005.

KROUSTRUP, J. P.; GUNDERSEN, H. J. Estimating the number of complex particles using the ConnEuler principle. Journal of Microscopy, v. 203, p. 314-320, 2001.

KÖNIG, H. E.; LIEBICH, H. G. Anatomia dos animais domésticos - texto e atlas. Porto Alegre: Editora Artmed, 2004. v. 2, p. 153. 
KURZ, B.; FEINDT, J.; GAUDECKER, V. B.; KRANZ, A.; LOPPNOW, H.; MENTLEIN, R. B- adrenoceptor-mediated effects in rat cultured thymic epithelial cells. Brazilian Journal Pharmacology, v. 120, p. 1401-1408, 1997.

LACERDA, L. L. Expressão Gênica de Células do Microambiente Tímico: modificações fenotípicas e funcionais após inativação do gene CD49e por interferência de RNA. 2008. Tese (Doutorado em Biologia Celular e Molecular)Instituto Oswaldo Cruz, Rio de janeiro, 2008.

LANGE, T.; GUTTMANN-RAVIV, N.; BARUCH, L.; MACHLUF, M.; NEUFELD, G. VEGF162, a new heparin-binding vascular endothelial growth factor splice form that is expressed in transformed human cells. Journal of Biological Chemistry, v. 278, p. 17164-17169, 2003.

LANG, I.; HOFFMAN, C.; OLIP, H.; PABST, M. A.; HAHN, T.; DOHR, G.; DESOYE, $G$. Differential mitogenic responses of human macrovascular and microvascular endothelial cells to cytokines underline their phenotypic heterogeneity. Cell Proliferation, Oxford, v. 34, n. 3, p. 143-155, 2001.

LEPOSAVIĆ, G.; MIĆIĆ, M.; UGREŠIĆ, N.; BOGOJEVIĆ, M.; ISAKOVIC, K. Componentes of sympathetic innervation of the rat thymus during late fetal and postnatal development: histofluorescence and biochemical study. Thymus, v. 19, p. 77-87, 1992.

LIN LI, C.; TODA, K.; SAIBARA, T.; ZHANG, T.; ONO, M.; IWASAKI, S.; MAEDA, T.; OKADA, T.; HAYASHI, Y.; ENZAN, H.; SHIZUTA, Y.; ONISHI, S. Estrogen deficiency results in enhanced expression of Smoothened of the Hedgehog signaling in the thymus and affects thymocyte development. International Immunopharmacology, v. 2, p. 823-833, 2002b.

LIN LI, C.; ZHANG, T.; SAIBARA, T.; NEMOTO, Y.; ONO, M.; AKISAWA, N.; IWASAKI, S.; MAEDA, T.; ONISHI, S. Thymosin a 1 accelerates restoration of T cellmediated neutralizing antibody response in immunocompromised hosts.

International Immunopharmacology, v. 2, p. 39-46, 2002a.

MACHADO, M. VEGF e vascularização ao longo do desenvolvimento e involução do timo em suínos. 2010. 146 p.Tese (Doutorado em Ciências) Faculdade de Medicina Veterinária e Zootecnia, Universidade de São Paulo, São Paulo, 2010. 
MANDARIM-DE-LACERDA, C. A. Manual de quantificação morfológica: morfologia, estereologia. 2. ed. Rio de Janeiro: 1994. 102 p.

MANDARIM-DE-LACERDA, C. A. Stereological tools in biomedical research. Anais da Academia Brasileira de Ciências, v. 75, n. 4, p. 469-489, 2003.

MARCHETTI, B.; MORALE, M. C.; PALLETIER, G. Sympathetic nervous system control of the rat thymus gland maturation: autoradiographic localization of the B2adrenergic receptor in the thymus and presence of sexual dimorphism during ontogeny. Neurology, Endocrinology and Immunology, v. 3, p. 103-114, 1990.

MAYHEW, T. M. A review of recent advances in sterology for quantifying neural structure. Journal Neurocytology, v. 21, p. 313-328, 1992.

MAYHEW, T. M.; GUNDERSEN, H. J. If you assume, you can make an ass out u and me: a decade of the disector for stereological counting of particles in 3D space. Journal of Anatomy, v. 188, n. 1, p. 1-15, 1996.

MAYHEW, T. M.; MWAMENGELE, G. L. M.; DANTZER, V. Comparative morphometry of the mammalian brain: estimates of cerebral volumes and cortical surface areas obtained from macroscopic slices. Journal of Anatomy, v. 172, p. 191-200, 1990.

MAYHEW, T. M.; OLSEN, D. R. Magnetic resonance imaging (MRI) and model-free estimates of brain volume determined using the cavalieri principle. Journal of Anatomy, v. 178, p. 133-144, 1991.

MATTFELDT, T.; MALL, G.; GHAREHBAGHI, H.; MOLLER, P. Estimation of surface area and length with the orientator. Journal of Microscopy, v. 159, p. 301-317, 1990.

MELO, A. M. A.; LAGE, M. C. D. Alguns aspectos da estrutura e funções do timo em Gallus domesticus. Repertório de Trabalhos do Laboratório Nacional de Investigação Veterinária, v. 19, p. 13-24, 1987.

NISSEN, N. N.; POLVERINI, P. J.; KOCH, A. E.; VOLIN, M. V.; GAMELLI, R. L.; DIPIETRO, L. A. Vascular endothelial growth factor mediates angiogenic activity during the proliferative phase of wound healing. The American journal of pathology, v. 152, n. 6, p. 1445-1452, 1998. 
NYENGAARD, J. R.; BENDTSEN, T. F.; GUNDERSEN, J. G. Stereological estimation of the number of capillaries, exemplified by renal glomeruli. Acta

Pathologica Microbiologica et Immunologica Scandinavica, p. 92-99, 1988.

Suplement, 4.

NYENGAARD, J. R.; MARCUSSEN, N. The number of glomerular capillares estimated by an unbiased and efficiente stereological method. Journal of Microscopy, v. 171, p. 27-37, 1993.

OLSEN, N. J.; KOVACS, W. J. Gonadal steroids and immunity. Endocrine Reviews, v. 17 , n. $4,1996$.

OLSON, I. A.; POSTE, M. E. The vascular supply of the thymus in the guinea-pig and pig. Immunology, v. 24, p. 253, 1973.

OLSZEWSKA-PAZDRAK, B.; HEIN, T. W.; OLSZEWSKA, P.; CARNEY, D. H. Chronica hypoxia attenuates VEGF signaling and angiogenic responses by downregulation of KDR in human endothelial cells. American Journal of Physiology. Cell Physiology, v. 296, n.5, p. 1162-1170, 2009.

PARK, J. E.; KELLER, G. A.; FERRARA, N. The vascular endothelial growth factor (VEGF) isoforms: differential deposition into the subepithelial extracellular matrix and bioactivity of extracellular matrix-bound VEGF. Molecular biology of the cell, v. 4, n. 12, p. 1317-1326, 1993.

PAKKENBERG, B.; BOESEN, J.; ALBECK, M.; GJERRIS, F. Unbiased and efficient estimation of total ventricular volume of the brain obtained from CT-scans by stereology method. Neuroradiology, v. 31, p. 413-417, 1989.

PAKKENBERG, B.; GUNDERSEN, H. J. Total number of neurons and glial cells in human brain nuclei estimated by disector and fractionator. Journal of microscopy, v. 150 , p. $1-20,1988$.

PFAFFL, M. W. A new mathematical model for relative quantification in real-time RTPCR. Nucleic Acids Research, v. 29, n. 9, p. 2002-2007, 2001.

POLTORAK, Z.; COHEN, T.; SIVAN, R.; KANDELIS, Y.; SPIRA, G.; VLODAVSKY, I.; KESHET, E.; NEUFELD, G. VEGF145, a secreted vascular endothelial growth factor isoform that binds to extracellular matrix. The Journal of Biological Chemistry, $v$. 272, n. 11, p. 7151-7158, 1997. 
RAICA, M.; ENCICA, S.; MOTOC, A.; CİMPEAN, A. M.; SCRIDON, T.; BÂRSAN, M. Structural heterogeneity and immunohistochemical profile of Hassall corpuscles in normal human thymus. Annals of Anatomy, v. 188, p. 345-352, 2006.

RISAU, W. Mechanisms of angiogenesis. Nature, v. 386, p. 671-674, 1997.

RITTER, M. A.; CRISPE, I. N. Structure and development. In: The thymus. New York: Oxford University Press, 1992. p. 9-24.

ROBINSON, C. J.; STRINGER, S. E. The splice variants of vascular endothelial growth factor (VEGF) and their receptors. Journal of Cell Science, Colchester, v. 114, n. 5, p. 853-865, 2001.

SCALA, G.; LANGELLA, M.; BUDETTA, G. Vascularization of the thymus in the duck. Bolletino della Societá Italiana di Biologia Sperimentale, v. 60, n. 4, p. 701706, 1984.

SENGER, D. R.; GALLI, S. J.; DVORAK, A. M.; PERRUZZI, C. A. HARVEY', V. S.; DVORAK, $H$. F. Tumor cells secrete a vascular permeability factor that promotes accumulation of ascites fluid. Science, v. 219, n. 4587, p. 983-985, 1983.

SHALABY, F.; ROSSANT, J.; YAMAGUCHI, T.P.; GERTSENSTEIN, M.; WU, X.F.; BREITMAN, M. L.; SCHUH, A. C. Failure of blood island formation and vasculogenesisin Flk-1-deficient mice. Nature, v. 376, p. 62-66, 1995.

SHARKEY, A. M.; DAY, K.; MCPHERSON, A.; MALIK, S.; LICENCE, D.; SMITH, S. K.; CHARNOCK-JONES, D. S. Vascular endothelial growth factor expression in human endometrium is regulated by hypoxia. The Journal of Clinical Endocrinology and Metabolism, v. 85, n. 1, p. 402-409, 2000.

SHEN, Y. H.; SCHOICHET, M. S.; RADISIC, M. Vascular endothelial growth factor immobilized in collagen scaffold promotes penetration and proliferation of endothelial cells. Acta Biomaterialia, v. 8, p. 477-489, 2008.

SHIBUYIA, M.; YAMAGUCHI, S.; YAMANE, A.; IKEDA, T.; TOJO, A.; MATSUSHIME, H.; SATO, M. Nucleotide sequence and expression of a novel human receptor-type tyrosine kinase gene (flt) closely related to the fms family.

Oncogenese, v. 5, p. 519-524, 1990. 
SILVA, F. O. C.; BOMBONATO, P.P.; SEVERINO, R. S.; DRUMMOND, S.S.;

SANTOS, A. L.Q; BORGES, M.; COSTA, C. Suprimento arterial do timo em cães SRD. Brazilian Journal Veterinary Research of Animal Science, v. 31, n. 2, p. 89-94, 1994.

SILVA, F. O. C.; SEVERINO, R. S.; SANTOS, A. L. Q.; DRUMMOND, A. S.; SILVA, M.; BOMBONATO, P. P.; REZENDE, R. J.; LIMA, E. M. M. Suprimento arterial do timo em gatos sem raça definida. Bioscience Journal, v. 17, n. 1, p. 61-66, 2001.

SMALLWOOD, J. E. The neck and shoulder regions. In . A guided tour of veterinary anatomy, Filadélfia: W. B. Saunder Co, 1992. p. 12-26.

SOLAROVIĆ, B. P.; LALIĆ, L.; LEPOSAVIĆ, G. Age-dependent morphometrical changes in the thymus of male propanolol-treated rats. Annals of Anatomy. n. 186, p 141-147, 2004.

STERIO, D. C. The unbiased estimation of number and sizes of arbitrary particles using disector. Journal of Microscopy, v. 134, p. 127-136, 1984.

STOUFFER, R. L.; MARTINEZ-CHEQUER, J. C.; MOLSKNESS, T. A.; XU, F.; HAZZARD, M. Regulation and action of angiogenic factors in the primate ovary. Archives of Medical Research, v. 32, p. 567-575, 2001.

SURTH, C. D.; SPRENT, J. T-cell apoptosis detected in situ during positive and negative selection in the thymus. Nature, v. 372, p. 100-103, 1994.

TAKAHAMA Y. Journey through the thymus: stromal guides for T-cell development and selection. Nature Reviews Immunology, v. 6, p. 127- 135, 2006.

TIZARD, I. Células e tecidos do sistema imunitário. In: Introdução a imunologia veterinária. 6. ed. São Paulo: Editora Roca, 2009. p. 76-92.

TERMAN, B. I.; DOUGHER-VERMAZEN, M.; CARRION, M. E.; DIMITROV, D.; ARMELLINO, D. C.; GOSPODAROWICZ, D.; BOHLEN, P. Identification of the KDR tyrosine kinase as a receptor for vascular endothelial cell growth factor. Biochemical And Biophysical Research Communications, New York, v. 187, n. 3, p. 15791586, 1992. 
VERSARI, R. Le arterie timiche nell'uomo ed in altri mammiferi. Loro rapporti colle arterie tiroidee. Bolletino della Società Lancisiana degli Ospedali di Roma, v. 17, p. 64-82, 1897.

VON GAUDECKER, V. B. Functional histology of the human thymus. Anatomy and Embriology, v. 183, p. 1-15, 1991.

WATANABE, N.; WANG, Y. H.; LEE, H. Hassall's corpuscles instruct dendritic cells to induce CD4+CD25+ regulatory T cells in the human thymus. Nature, v. 436, p. 1181-1185, 2005.

WILKINSON, B.; OWEN, J. J. T.; JENKINSON, E. J. Factors regulating stem cell recruitment to the fetal thymus. The Journal of Immunology, v. 162, n. 7, p. 38733881, 1999.

WINDMILL, K. F.; LEE, V. W. K. Effects of castration on the lymphocytes of the thymus, spleen and lymph nodes. Tissue \& Cell, v. 30, n. 1, p. 104-111, 1998.

WINDMILL, K. F.; MEADE, B. J.; LEE, V. W. K. Effect of prepubertal gonadectomy and sex steroid treatment on the growth and lymphocyte populations of the rat thymus. Reproduction Fertility Development, v. 5, p. 73-81, 1993.

YANCOPOULOS, G. D.; DAVIS, S.; GALE, N. W.; RUDGE, J. S.; HOLASH, W.; HOLASH, J. Vascular-specific growth factors and blood vessel formation, Nature, v. 407, p. 242-248, 2000.

ZYGMUNT, M.; HERR, F.; MUNSTEDT, K.; UWE, L.; LIANG, O. D. Angiogenesis and vasculogenesis in pregnancy. European Journal of Obstrics \& Gynecology and Reproductive Biology, v. 110, p. S10-S18, 2003.

WULFSOHN, D.; GUNDERSEN, H. J.; VEDEL JENSEN, E. B.; NYENGAARD, J. R. Volume estimation from projections. Journal of Microscopy, v. 215, p. 111-120, 2004. 